\title{
SUMMARY \\ OF
}

\section{GROUND-WATER CONDITIONS}

IN

MICHIGAN

IN

1964

BY

P. R. GIROUX AND G. C. HUFFMAN

U. S. GEOLOGICAL SURVEY

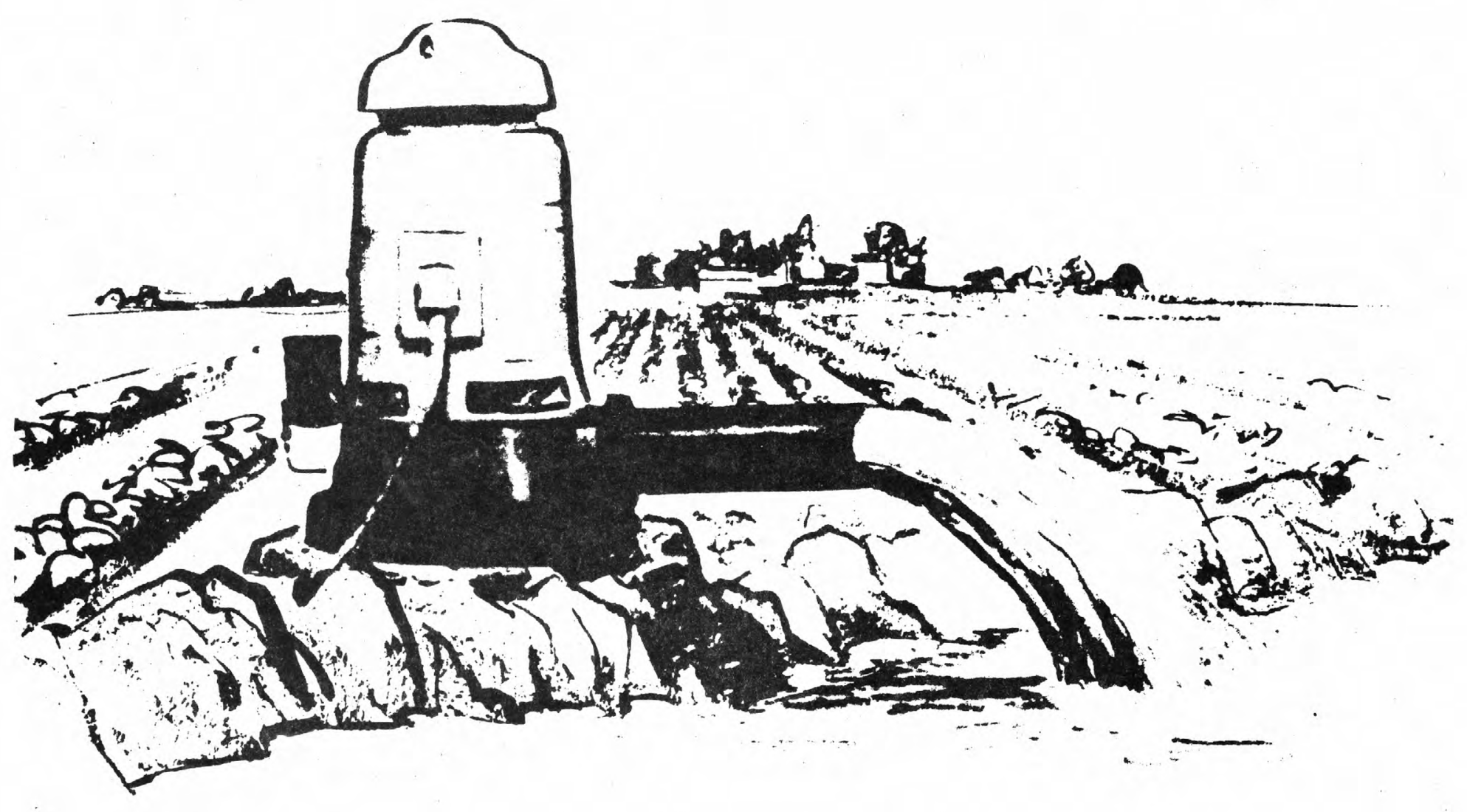

PREPARED IN COOPERATION WITH THE

STATE OF MICHIGAN

DEPARTMENT OF CONSERVATION

R. A. MacMULLAN, DIRECTOR

GEOLOGICAL SURVEY DIVISION

G. E. EDDY, STATE GEOLOGIST 

SUMMARY

OF

GROUND-WATER CONDITIONS

IN

MICHIGAN

IN

1964

BY

P. R. GIROUX AND G. C. HUFFMAN U. S. GEOLOGICAL SURVEY

Prepared in cooperation with the State of Michigan Department of Conservation R. A. MacMullen, Director Geological Survey Section G. E. Eddy, State Geologist 

Acknowledgment is made to personnel of Federal and State agencies, county and township governments, industrial concerns, we 11 drillers, consultants, municipalities and public utilities without whose cooperation the accumulation of the basic data presented in this report would have not been possible.

The authors are grateful to Messrs. J. G. Rulison and A. E. Slaughter of the Michigan Geological Survey for their help in the editing of this report.

This report summarizes and evaluates records of ground-water levels and related hydrologic information obtained by the U. S. Geological Survey as part of the overa11 water resources investigation in Michigan carried out in cooperation with the State Geologica1 Survey.

This program of ground-water investigations in Michigan is conducted in cooperation with the Michigan Department of Conservation, R. A. MacMullan, Director, through the Geological Survey Section, G. E. Eddy, State Geologist, and under the overall agreement for water-resources investigations in Michigan with the State Water Resources Commission, L. F. Oeming, Executive Secretary.

The collection of ground-water leve 1 records and other related data is also aided by the following municipalities, institutions and private organizations:

Cities and villages of Alma, Ann Arbor, Battle Creek, Beaverton, Cadillac, Coldwater, Dowagiac, Grand Ledge, Greenville, Hastings, Hillsdale, Holland, Ironwood, Jackson, Kalamazoo, Lansing, Lowe11, Marsha11, Manistee, Mason, Plymouth, Pontiac, Rochester, St. Johns, St. Louis, Wyoming, Ypsilanti; the townships of Battle Creek, Waterford and Ypsilanti; Cranbrook School, Michigan College of Mining and Technology, Oakland University; State institutions at Howe11, Ionia, and Ypsilanti; the County of Van Buren; Huron-C1inton Metropolitan Authority; the Fisher Body Division of General Motors Corporation, the Jervis Corporation, KVP-Sutherland Paper Company and the Wisconsin-Michigan Power Company. 
In addition to this series of water-level reports, records and interpretations of water levels in Michigan have been published annually as U. S. Geological Survey Water Supply Papers entitled 'Water Levels and Artesian Pressures in the United States". The following tabulation lists the papers containing water-level data for Michigan:

$\begin{array}{llrrrr}\text { Year } & \text { No. } & \text { Year } & \text { No. } & \text { Year } & \text { No. } \\ 1935 & 777 & 1942 & 944 & 1949 & 1156 \\ 1936 & 817 & 1943 & 986 & 1950 & 1165 \\ 1937 & 840 & 1944 & 1016 & 1951 & 1191 \\ 1938 & 845 & 1945 & 1023 & 1952 & 1221 \\ 1939 & 886 & 1946 & 1071 & 1953 & 1265 \\ 1940 & 906 & 1947 & 1096 & 1954 & 1321 \\ 1941 & 936 & 1948 & 1126 & 1955 & 1404\end{array}$

Beginning in 1956 the annual publication of this series of watersupply papers was discontinued. The series was changed to include a reduced amount of water level records, and the interpretative text was eliminated. The first of this reduced series was published for the two years 1956-57 as WaterSupply Paper No. 1537 and subsequent reports of this series are being published on 1 y every 5 years.

To supplement this abbreviated report, a local series of annual reports was begun for Michigan in 1956 and entitled "Summary of Ground-Water Conditions in Michigan". The first seven of these reports were published by the Michigan Department of Conservation for the years 1956-62. The 1963 report and this report are open-file reports.

Selected publications dealing with ground-water conditions in Michigan are listed under REFERENCES at the end of this report.

How open-file data and published records can be obtained

Complete tabulations of water-level measurements and hydrographs for individual observation wells, records of chemical quality of ground-water, watertemperature measurements, we11 records including logs, aquifer tests, records of pumping for public supply and industrial use, and published and unpublished waterresource reports are on file for public inspection. They may be examined at the office of the Water Resources Section of the Michigan Geological Survey, Fourth Floor, Mason Building, Lansing, or at the Michigan District office of the U. S. Geological Survey, 700 Capitol Savings and Loan Building, Lansing. Records for the Northern Peninsula are also kept on file in the office of the State and Federal Geological Surveys, 203 State Office Building, Escanaba. 
U. S. Geological Survey Water-Supply Papers are for sale by the Superintendent of Documents, U. S. Government Printing Office, Washington 25, D. C., or can be consulted at the offices listed above and in major university or municipal libraries.

The Federa1 Survey also issues a month1y publication entitled 'Water Resources Review" which briefly summarizes ground-water levels and streamflow throughout the United States. The monthly issues can be obtained free of charge by application to the Director, U. S. Geological Survey, Washington, D. C. 20242.

Copies of annual "Summaries of Ground-Water Conditions in Michigan" are free on application, while other publications of the Michigan Geological Survey can be purchased from the Michigan Department of Conservation, Publications Room, Mason Building, Lansing 26, Michigan.

Reports of cooperative ground-water investigations covering specific areas of the State are also published by the Michigan Geological Survey or the U. S. Geological Survey. These reports are also available for inspection at the offices listed above. 

TABLE OF CONTENTS

Page

Preface ............................... . . iii

Previous investigations ...................... . iv

How open-file data and published records can be obtained . . . . . iv

Introduction . . . . . . . . . . . . . . . . . . . . . . . 1

Purpose of this report ...................... 1

What this report contains .................... . 1

Ground water levels in 1964 . . . . . . . . . . . . . . . . . 3

Number and location of wells ............... . . . 3

Effects of precipitation on ground-water levels . . . . . . . . 3

Changes in ground-water storage from natural influences . . . . . . 7 .

Changes in storage from pumping influences . . . . . . . . . . 15

Barry County - City of Hastings . . . . . . . . . . . 17

Bay County - Pinconning Township . . . . . . . . . . . . 19

Branch County - City of Coldwater . . . . . . . . . . . . 21

Calhoun County - City of Battle Creek . . . . . . . . . . 23

Calhoun County - Battle Creek Township . . . . . . . . . 25

Clinton County - City of St. Johns . . . . . . . . . . . 27

Eaton County - City of Grand Ledge . . . . . . . . . . . . 29

Genesee County - Fisher Body, GMC, at Grand Blanc . . . . . . 31

Gogebic County - City of Ironwood . . . . . . . . . . . . 33

Gratiot County - City of Alma . . . . . . . . . . . . 37

Gratiot County - City of St. Louis . . . . . . . . . . 39

Ingham County - City of Lansing . . . . . . . . . . . . . 41

Ingham County - City of East Lansing . . . . . . . . . . . . 44

Ingham County - Lansing Township . . . . . . . . . . . 45

Ingham County - Meridian Township . . . . . . . . . . . 46

Ingham County - Michigan State University . . . . . . . . 47

Ingham County - City of Mason . . . . . . . . . . . . 49

Jackson County - City of Jackson . . . . . . . . . . . 51

Kalamazoo County - City of Kalamazoo . . . . . . . . . . 55

Kent County - City of Lowel1 . . . . . . . . . . . . 59

Kent County - City of Wyoming . . . . . . . . . . . 61

Macomb County .. . . . . . . . . . . . . . . 65

Manistee County - City of Manistee . . . . . . . . . . . 67

Oakland County - Oakland University . . . . . . . . . . . 69

Oakland County - City of Pontiac . . . . . . . . . . . 71

Oakland County - Village of Rochester . . . . . . . . . 73

Oakland County - Waterford Township . . . . . . . . . . 75

Van Buren County .. . . . . . . . . . . . . . . 77

Washtenaw County - City of Ann Arbor . . . . . . . . . . 81

Washtenaw County - City of Ypsilanti . . . . . . . . . 83

Washtenaw County - Ypsilanti Township . . . . . . . . . 85

Wayne County - City of Plymouth . . . . . . . . . . . 87

Wexford County - City of Cadillac . . . . . . . . . . . 89

Ground-water resources investigations in Michigan . . . . . . . . . . . 91

Reports of investigations . . . . . . . . . . . . . . . . . . 91

Selected references . . . . . . . . . . . . . . . . . . . . 91 
Figure 1.--Map showing location of observation we11s in Michigan, 1964 .4-5

2.--Map showing total departure of precipitation by regions in Michigan, 1960-64..................... 6

3.--Graphs showing month-end levels in key observation we 11s in Michigan, 1964 . . . . . . . . . . . . . 8

4.--Graph of water levels in a well and precipitation, Chippewa County, 1960-64..................

5.--Recorder charts showing fluctuations of water levels in four we11s in the Lower Peninsula . . . . . . . . . .

6.--Recorder charts showing fluctuation of water levels in four we11s as a result of the March 27 (Good Friday) Alaskan earthquake .. . . . . . . . . . . . . . .

7.--Graph of water leve1s in a we11, pumpage, and precipitation at Hastings, 1960-64 . . . . . . . . . . . . .

8.--Graphs showing water levels in a wel1 in Pinconning Township, pumpage at Pinconning, and precipitation, 1962-64. . .

9.--Recorder charts showing changes in water levels in three wells in and near Coldwater in Branch County . . . . . . .

10.--Graphs showing water levels in a well at Verona Station, pumpage and precipitation, at Battle Creek, 1960-64. . .

11.--Graph showing water levels in a well in Battle Creek Township, and precipitation, November 1964 through Apri1 1965 . . .

12.--Graphs showing water levels in two we11s, pumpage and precipitation, St. Johns, 1963-64 ............ . 26

13.--Graphs of water leve1s, pumpage, and precipitation, Grand

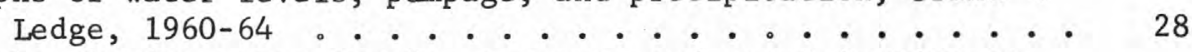

14.--Graphs showing water leve1s, pumpage, and precipitation at the Fisher Body Plant near Grand Blanc, 1960-64 . . . . . 30

15.--Graphs showing water levels in two wells, pumpage at Spring Creek field, and precipitation, Ironwood, 1961-64 . . . .

16.--Graphs showing water levels in two wells, and pumpage at Big Spring field at Ironwood; and well location map . . . . .

17.--Graphs showing water levels, pumpage, and precipitation, Alma,

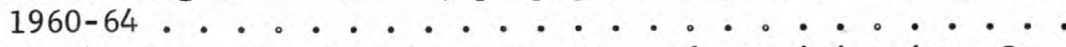

18.--Graphs showing water levels, pumpage, and precipitation, St. Louis, 1960-64 ..................... 38

19.--Graphs showing water levels in two we11s, pumpage and precipitation, Lansing, 1960-64 .. . . . . . . . . .

20.--Graphs showing water levels in three wells in the Lansing area, 1960-64, and one we11 April-December, 1964 . . . 42

21.--Location map of observation wells in the Tri-County area surrounding Lansing . . . . . . . . . . . . .

22.--Graphs showing water levels, pumpage, and precipitation, Mason, 1963-64..................... . . . .

23.--Graphs showing water levels in three wells, pumpage and precipitation, Jackson, 1960-64 .......... 50 
Figure 24.--Graphs showing water levels in three we11s, and stages of the Grand River, 1963-64, and location map of observation wells, Jackson . . . . . . . . . . . . . . . . .

25.--Graphs of water leve1s, pumpage, and precipitation, Kalamazoo, 1960-64 .................. 54

26.--Graphs of water levels in two we11s, pumpage and precipitation, Kalamazoo, 1960-64 ................ 56

27.--Map of Kalamazoo area showing location of observation we11s. 57

28.--Graphs showing water levels, pumpage, and precipitation, Lowe 11, 1961-64 ............... . . 58

29.--Graphs showing water levels in three we11s, pumpage, and precipitation, Wyoming, 1960-64.......... 60

30.--Graphs showing water levels in three we11s, and precipitation, Wyoming, 1962-64 ............. 62

31.--Location map of we11s at Wyoming . . . . . . . . . 63

32.--Graphs showing water levels in four we11s and Stony Lake, near Rochester, 1963-64 . . . . . . . . . . 64

33.--Location of observation we11s at Stony Creek Park, near Rochester ................... . . 65

34.--Recorder chart showing changes in water levels owing to occasional pumping of a well field at Manistee . . . . . 66

35.--Graphs showing water levels, pumpage, precipitation, Oakland University near Pontiac, 1961-64 . . . . . . . . .

36.--Graphs showing water levels, pumpage, and precipitation, Pontiac, 1960-64 ................... 70

37.--Graphs showing water leve1s in a we11, pumpage, and precipitation, at Rochester, 1961-64 . . . . . . . . . .

38.--Graphs of water levels, pumpage, and precipitation, Waterford Township, 1960-64.................... 74

39.--Graphs of water levels in three wells equipped with recording gages, Van Buren County, 1963-64 ........... 76

40.--Graphs showing water levels in five wells tapping the glacial drift in Van Buren County, 1963-64 . . . . . . . . 79

41.--Graphs of water levels in two we11s, ground-water pumpage, and precipitation, Ann Arbor, 1962-64 .. . . . . . . 80

42.--Graphs of water levels in two we11s, pumpage, and precipitation, Ypsilanti, 1960-64 . . . . . . . . . . 82

43.--Graphs of water levels in two wells, pumpage, and precipitation, Ypsilanti Township, 1960-64......... 84

44.--Graphs showing water levels in two we11s, pumpage, and precipitation, Plymouth, 1962-64............

45.--Graphs of water levels, pumpage, and precipitation, Cadillac,

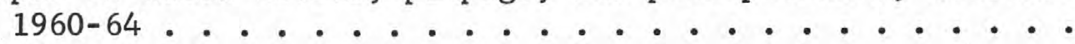

Table 1.--Fluctuations of water levels in some Michigan observation wells in response to the great Alaskan earthquake . . . . . 
ILLUSTRATIONS AND TABLES.--Continued

Page

Table 2.--Records of Michigan observation wells and extremes in water levels observed in 1964 and for the period of record . .
3.--Reported ground-water pumpage by some Michigan municipalities, 95 institutions, and industries (in million ga11ons) . . . 104 
SUMMARY OF GROUND-WATER CONDITIONS

IN MICHIGAN IN 1964

INTRODUCTION

Purpose of this report

The purpose of this report is to make available records of groundwater level changes in the principal aquifers of the State during 1964 and compile other related data, such as ground-water pumpage, data on municipal, public and industrial water supply facilities, and the effects of precipitation on ground-water levels. Records of water level changes in areas of heavy pumpage and in areas where changes are principally from natural influences are illustrated or tabulated (table 2) to allow comparison between these two types of water-1eve1 fluctuations. The water-leve 1 and related data provide a day-to-day evaluation of available ground-water supplies. These long-term records serve as a framework to which many short-term records collected during an intensive investigation may be related.

This report is written for those persons, municipalities, industries, institutions, consultants, drillers and hydrologists interested in the groundwater resources of the State.

\section{What this report contains}

This report contains the records of measurements of ground-water levels in observation we11s in Michigan. These water-level records are listed in Table 2 which also shows the location and depth of we11, elevation of land surface, aquifer from which the water is obtained and the extremes of water level for the past record and in the year 1964. Table 3 contains records of ground-water pumpage of most major water users in the State in 1964.

Numerous hydrographs are included in the report to illustrate the changes of water level and most of these illustrations a1so show the effects of ground-water pumpage and variations of precipitation on water levels in we11s.

The text gives supplementary data on the yield of we1ls, pumpage, storage facilities, treatment, quality of water such as hardness and iron, per capita use and trends of ground-water levels for 1964 and for the period of previous record. 
The yie1d of we1ls is shown as a range of production in gallons per minute (gpm) for a11 the we11s or specifical1y for each we11. The specific capacity (gallons per minute per foot of drawdown in the we11) is also given as a range or specifically for each well. Yield and specific capacity data are reported figures from water departments and consultants. 
GROUND WATER LEVELS IN 1964

Ground-water levels fell to record low stages in many parts of the State in 1964 as a result of continued deficiencies of precipitation. In some urban areas increased pumpage also contributed to the decline.

\author{
Number and location of wells
}

In 1964 measurements were made on a tota1 of 334 observation we11s, 87 of which were equipped with continuous recording gages, general location of which are shown by figure 1 and by several map inserts in the body of the report. The location map (fig. 1) also shows the rectangular subdivision of the land and the numbering system of the land divisions by use of the base line and north-south meridian. The we11-numbering system used by the State and Federal Surveys in Michigan indicates the location of wells within the rectangular subdivision of the land with reference to the Michigan meridian and base line. The first two segments of a well number designate township and range; the third segment designates both the section and the well within the section. Thus, well number $32 \mathrm{~N}$ 6E 16-1 is we 11 number 1 in section 16, Township 32 North, Range 6 East. Table 2 lists the wells by counties and then by rectangular division.

\title{
Effects of precipitation on ground-water levels
}

Precipitation is the major climatic factor affecting ground-water levels in any area. Hydrographs of natural fluctuations of water in wells (figs. 3-5) show that spring and fall are the seasons when water levels are highest and when most of the ground-water recharge occurs. In the spring before the growing season starts, snowmelt and rain normally result in large additions to the ground-water reservoirs. However, ice cover or frost in the ground can impede infiltration when the first thaws occur. Under these conditions, most of the water from snowmelt and early spring precipitation may be lost by quick surface runoff. During the growing season most of the rainfall either runs off when it occurs as heavy showers or is evaporated or transpired by vegetation. Thus, very little recharge finds its way to the water table. During the winter frozen ground in heavy soil areas impedes the infiltration of water into the ground except when prolonged winter thaws occur. In the fall after the growing season ends, evapotranspiration (water withdrawn by evaporation and by transpiration from plants) is reduced by cold weather. Thus, substantial rises in water levels follow the usual fall rains. 
ISLE ROYALE

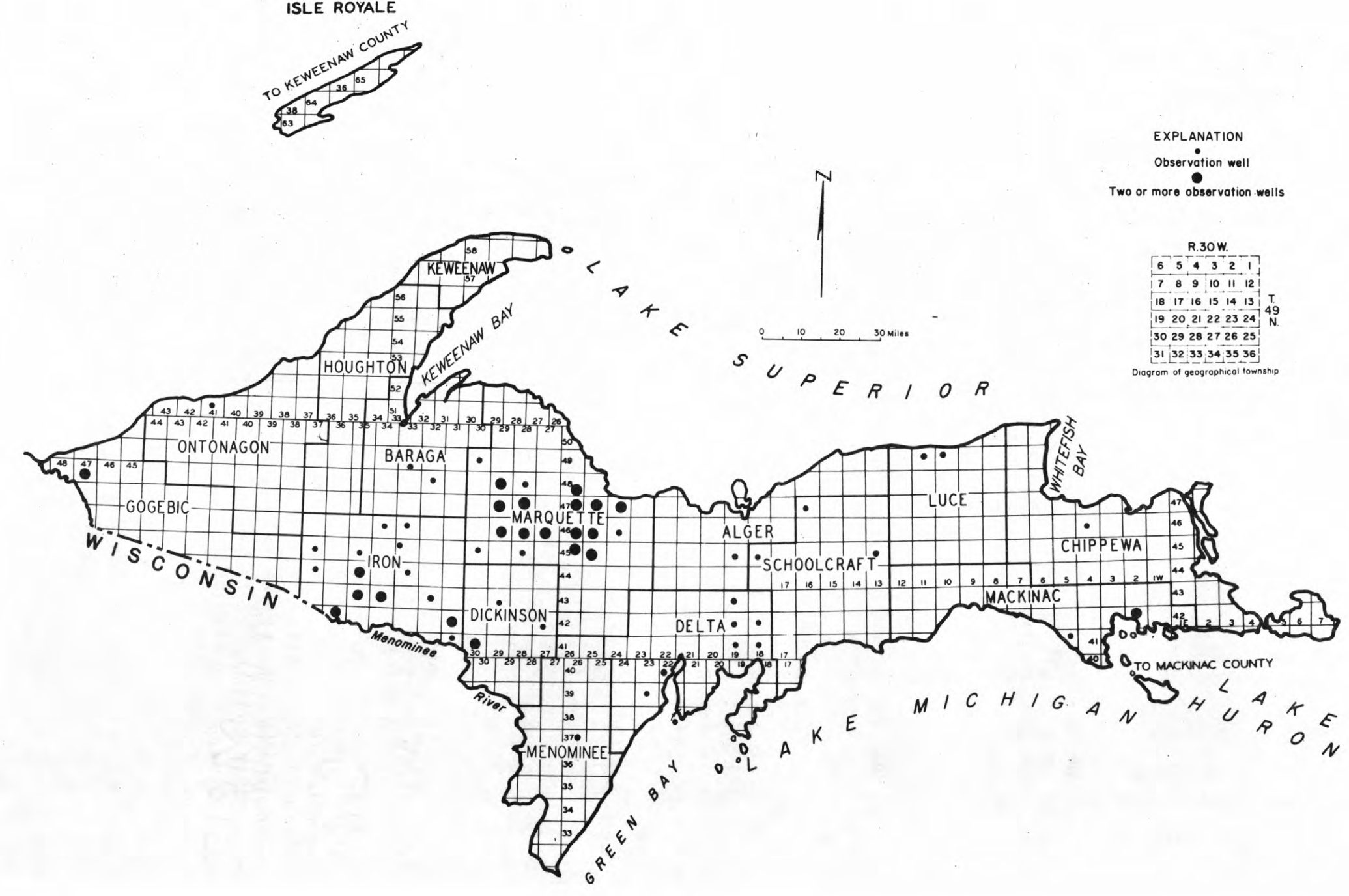




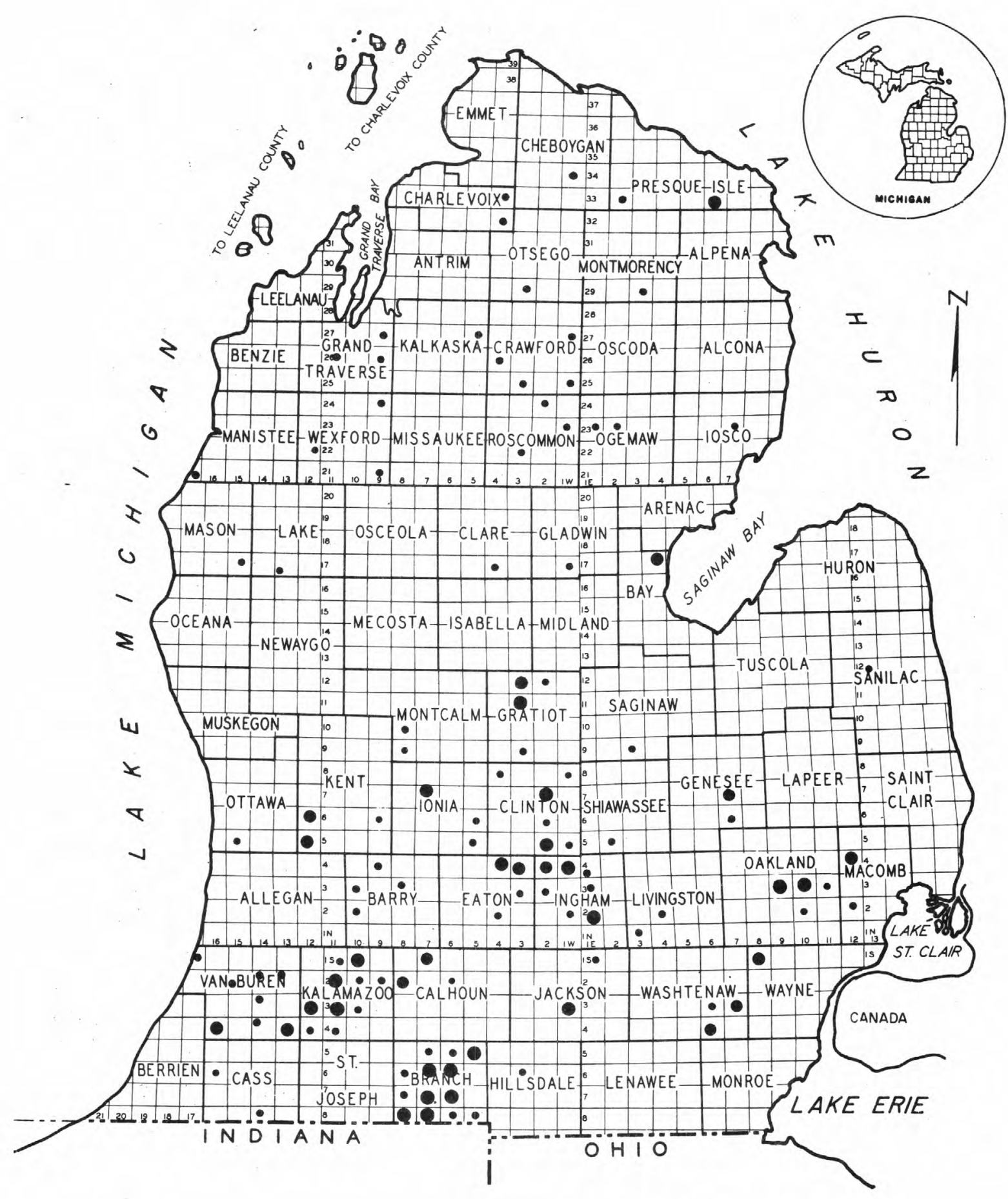

FIGURE 1.--MAP SHOWING LOCATION OF OBSERVATION WELLS IN MICHIGAN, 1964.

Records of water levels were obtained from 334 observation we1ls, 87 of which were equipped with continuous recording gages. (see Table 2) 


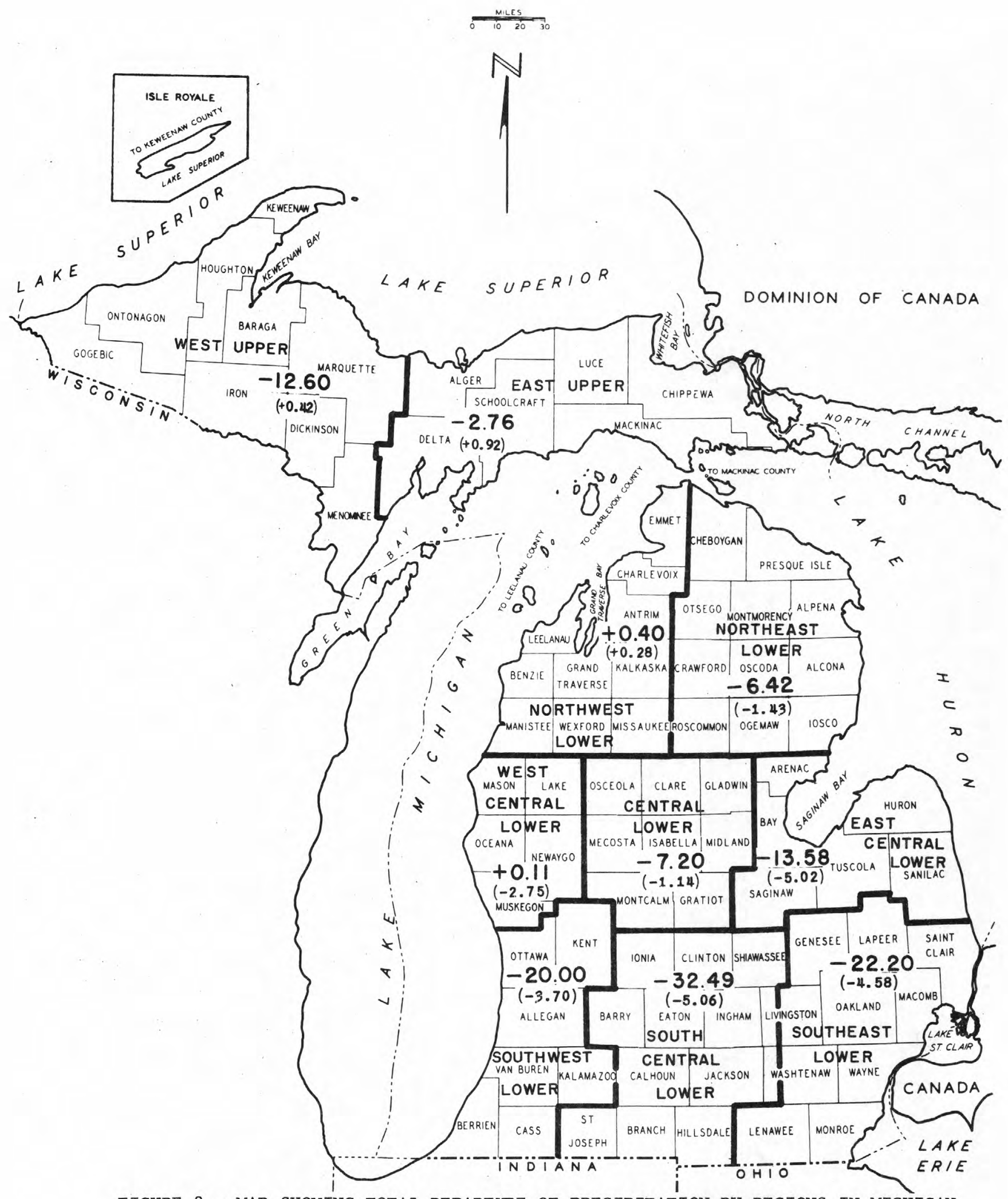

FIGURE 2.--MAP SHOWING TOTAL DEPARTURE OF PRECIPITATION BY REGIONS IN MICHIGAN, 1960-64.

Large deficiencies of precipitation occurred during this five-year period. The figures in parenthesis represent departure for the year 1964. 
According to the U. S. Weather Bureau, precipitation in 1964 was below average in 7 of the 10 climatological divisions of the State. Departures ranged from 0.92 inches above in the eastern half of the upper peninsula to 5.06 inches below normal in the south-central part of the lower peninsula (fig. 2). The overall precipitation deficiencies of the past five years (fig. 2) have resulted in record- or near-record low ground-water levels, especially in the "southcentral lower" area where precipitation has been very deficient. Many of the illustrations in this report include graphs showing the local cumulative departures of annual precipitation from the long-term mean. These graphs were constructed by using the "zero" or "average" line to denote the average precipitation for the period of record preceding the period of the graph. Starting at this line the excess or deficiency of precipitation for each month or year is added algebraically. Thus, for each time unit, a line sloping downward indicates belowaverage precipitation, and a line sloping upward indicates above-average precipitation. In cumulative graphs such as these, the slope of the line is the important part -- that is, even where the graph is far below the zero line, if the slope is upward, that part of the period is one of above-average precipitation. The end point thus gives the total rainfal1 above or below the previous average for the entire period of the graph.

\section{Changes in ground-water storage from natural influences}

Water levels in 11 key wells in Michigan continued to be low to record low in 1964 (fig. 3). Stages were especially low in the southern part of the lower peninsula. The low levels were the result of continuing deficiencies of precipitation in much of the State.

Levels in other we11s throughout the State reflecting changes in storage from natural influences were also in low to record low stages (table 2).

In Chippewa County water levels in a key well (fig. 4) rose in 1964 in response to above-average precipitation following four years of decline.

A typical spring rise and summer decline of water levels is shown by charts $A$ and $B$ in figure 5 .

In addition to changes in water levels in wells from the effects of precipitation, such phenomena as earth tide, barometric pressure variations, evapotranspiration, and earthquakes also cause changes in levels. Evapotranspiration causes sma11 daily losses in water levels in we11s, but the others ordinarily cause on ly temporary changes.

Many earthquakes occurring in various parts of the world are recorded each year in Michigan observation we11s as fluctuations in water level of short duration. At 5:36 p.m., Alaskan Standard Time (10:36 p.m. Eastern Standard Time) on Good Friday, March 27, 1964, a great earthquake crippled south-central Alaska. It released at least twice as much energy as the 1906 earthquake which wracked San Francisco, and was felt on land over an area of almost half a million square miles. Fifty of the eighty observation wells equipped with water-stage recorders in Michigan registered fluctuations resulting from the seismic wave caused by this Alaskan quake. Table 1 lists the wells and records of these fluctuations 
Water levels are in feet below land-surface
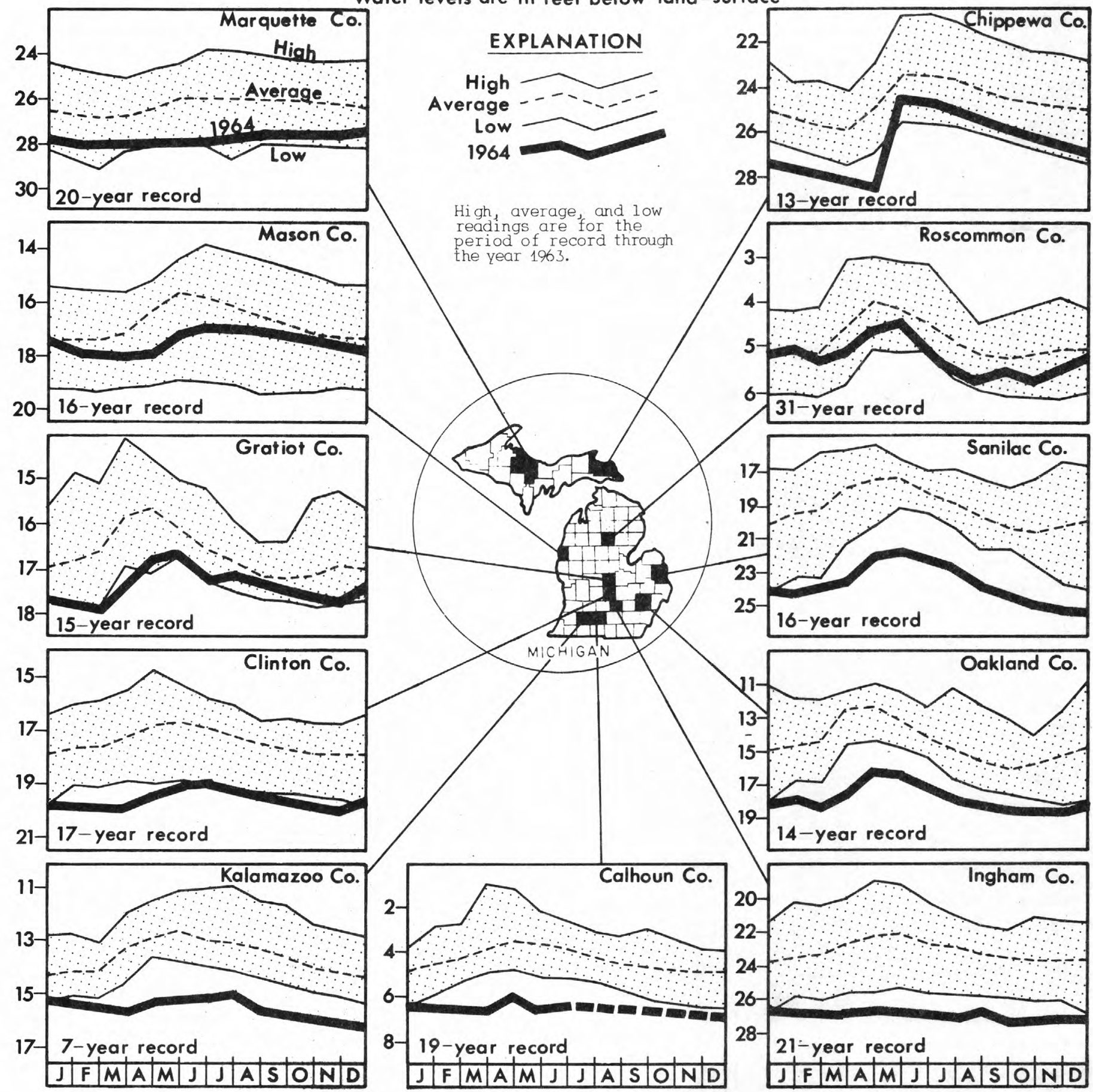

FIGURE 3 .--GRAPHS SHOWING MONTH-END LEVELS IN KEY OBSERVATION WELLS IN MICHIGAN, 1964.

Water levels were especially low in the southern half of the Lower Peninsula. 

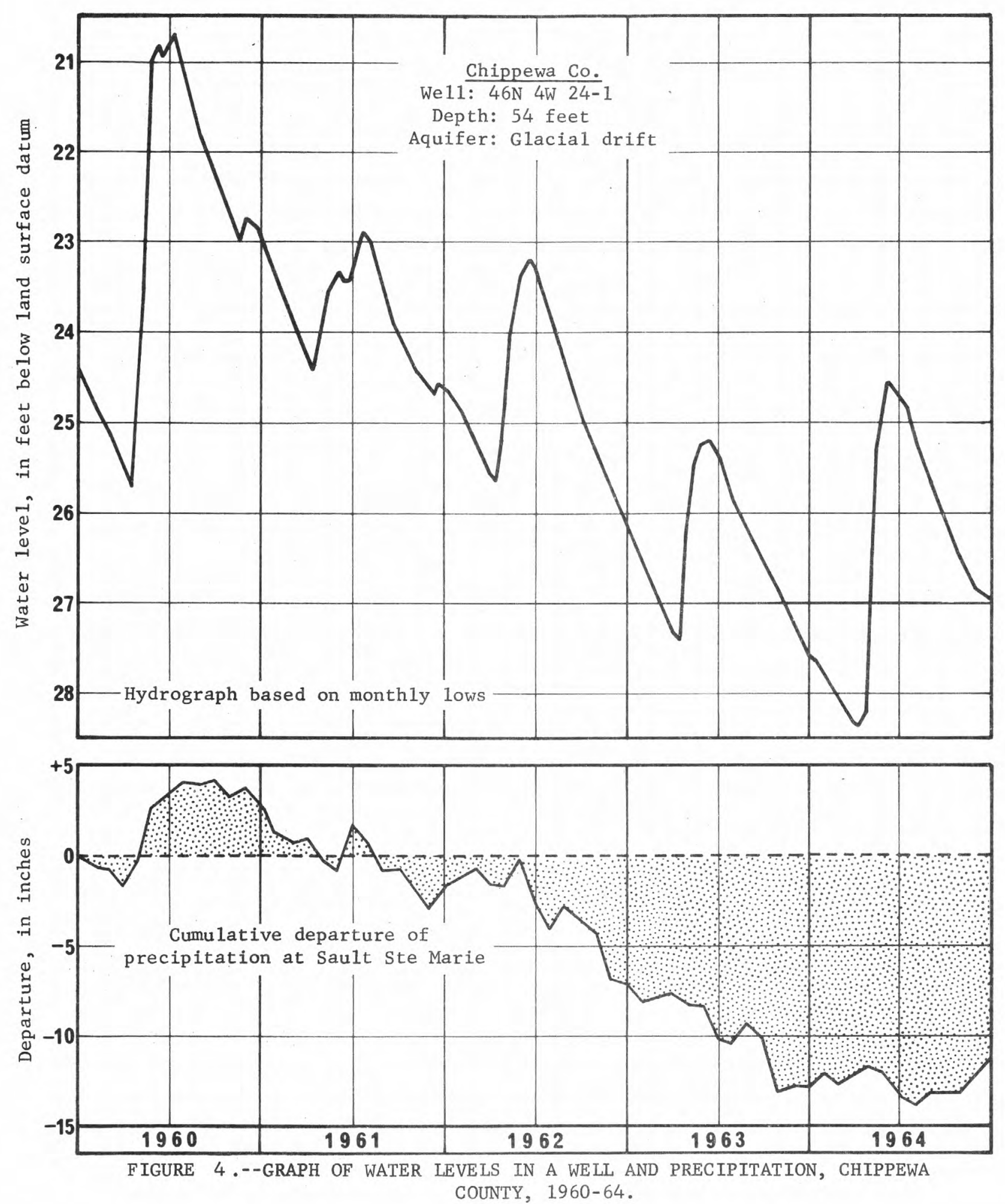

This is a striking example of the correlation between precipitation and water levels in a well. 

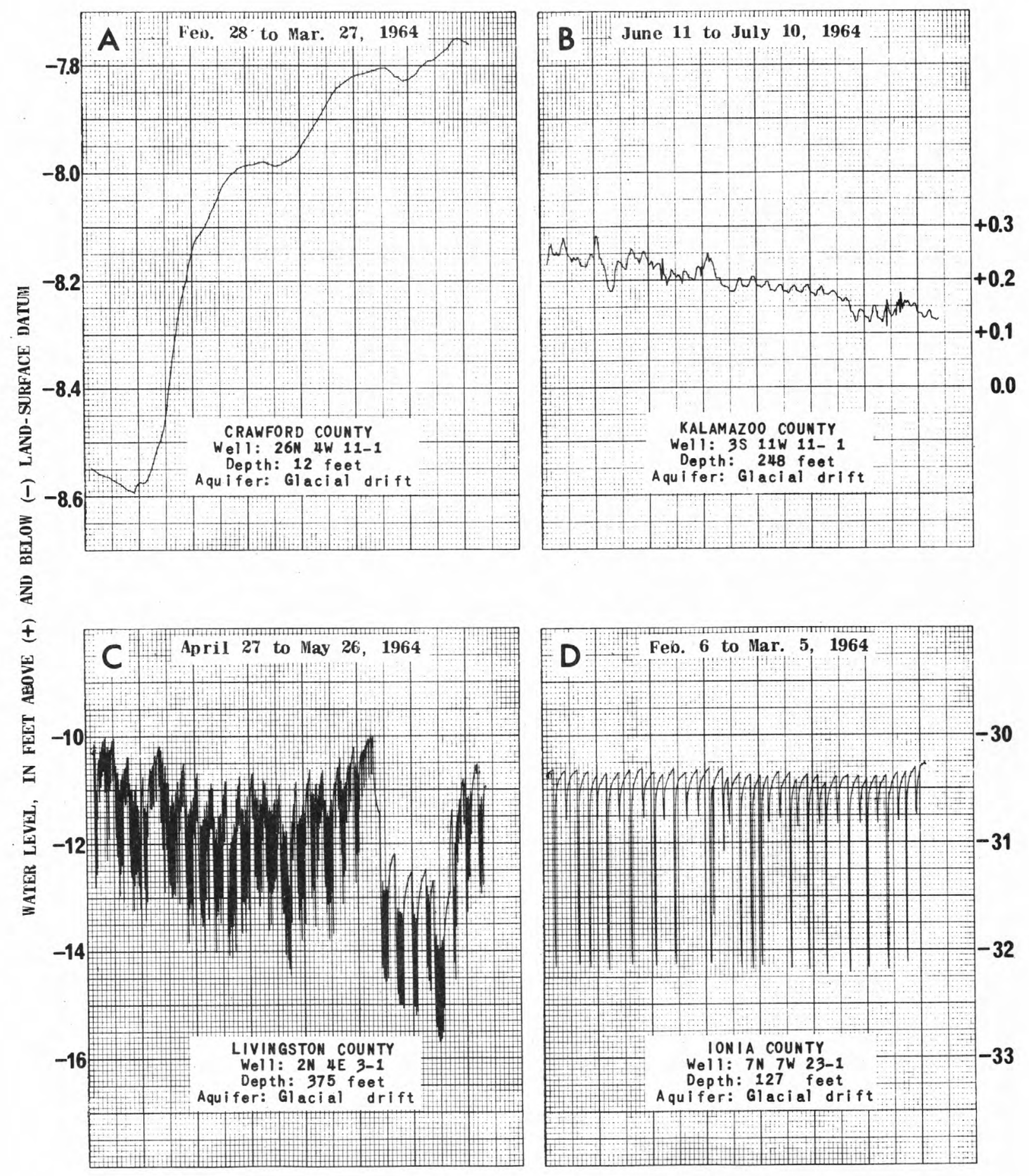

FIGURE 5.--RECORDER CHARTS SHOWING FLUCTUATIONS OF WATER LEVELS IN FOUR WELLS IN THE LOWER PENINSULA.

Chart A shows the annual spring rise of water levels; Chart B shows typical summer decline; Charts C \& D show fluctuation of water levels in response to nearby pumping. 
Table 1.--Fluctuations of water levels in some Michigan observation we11s in response to the great Alaskan earthquake.--Continued.

\section{County}

and

We11 No.

Ionia Co.

Ionia State
Hospital

Jackson Co.

3S 1W 2-1

3S $1 \mathrm{~W} 10-1$

City of Jackson

Summit Township

3s 1W 11-3

City of Jackson $\begin{array}{cc}\text { We11 } & { }^{*} \text { Chief } \\ \text { Depth } & \text { aqui- } \\ \text { (feet) } & \text { fer }\end{array}$

Depth to water below land

\begin{tabular}{l} 
surface datum, in feet \\
\hline Before After High Low
\end{tabular}

Total range

0.015

3.73

1.57

0.08

Kalamazoo Co.

2S 11W 20-11 City of Kalama-

2S $11 \mathrm{~W} \quad 20-11$

3S $12 \mathrm{~W} 11-1$

Do.

81 Qgd

17.20

17.20

17.185

17.17

17.23

0.06

81
248

Qgd

17.185

$+0.365$

${ }^{c} 17.1655^{c} 17.205$

$\mathrm{c}_{0.04}$

Qgd

$+0.365$

$+0.485+0.285$

0.20

Kent Co.

$6 \mathrm{~N} \mathrm{12W} \mathrm{27-1}$

$6 \mathrm{~N} \quad 9 \mathrm{~W} \quad 3-1$

City of Wyoming

265

City of Lowe11

Mm $\quad 52.65$

52.65

52.25

53.05

0.80

Qgd 17.55

17.55

17.53

17.57

68.21

68.21

Do.

300

$\mathrm{Mm}$
$\mathrm{Mm}$$\quad 8.63$

8.63

a 65.71

a 70.71

Qgd 11.77

11.79

8.44

8.85

11.34

12.12

0.04

a. 5.00

0.41

0.78

Livingston

Co.

2N 3 4E 3 Howe11 State Hospital

148

Ps

12.75

12.75

10.48

15.02

4.54

Mackinac Co. $42 \mathrm{~N} 2 \mathrm{~W} \mathrm{7-1}$
U. S. Forest Service

102

Sm $\quad 25.70$

25.70

23.50

28.30

4.80

Manistee Co. 21N 17W 14-1

City of Manistee

212

Qgd $\quad 33.06 \quad 33.06$

$32.93 \quad 33.235$

0.305

Marquette

$\frac{\mathrm{Co}}{47 \mathrm{~N} \mathrm{2} 8 \mathrm{~W} \mathrm{3-1}}$

E1y Township

75

Qgd

19.09

19.10

18.79

19.54

0.75

Oakland Co.

$\begin{array}{lll}3 N & 9 E & 36-1 \\ 3 N & 10 E & 13-2 \\ 3 N & 10 E & 31-1 \\ 3 N & 10 E & 32-1 \\ 3 N & 11 E & 4-1\end{array}$

Waterford Township

134

Oakland Univ.

City of Pontiac Do.

183

173

Village of

160

$\begin{array}{ll}\text { Qgd } & 96.78 \\ \text { Qgd } & 86.80 \\ \text { Qgd } & 78.85 \\ \text { Qgd } & 79.90 \\ & \\ \text { Qgd } & 28.60\end{array}$

96.78

96.75

96.81

86.80

85.75

87.85

78.85

78.50

79.30

81.00

79.90

79.10

$28.35 \quad 28.85$

28.60

28.35

73

\section{Rochester}


Table 1.--Fluctuations of water levels in some Michigan observation wells in response to the great Alaskan earthquake.

This earthquake occurred in south-central Alaska on Good Friday, March 27, 1964, at 5:36 p.m., Alaskan Standard Time (10:36 Eastern Standard Time). Major fluctuations of water levels occurred between 11:00 and 11:30 p.m., March 27, in Michigan.

\section{County \\ and}

We11 No.
Owner
We11

Depth

(feet)

$$
\begin{gathered}
\text { *Chief } \\
\text { aqui- } \\
\text { fer }
\end{gathered}
$$

Depth to water below land

$\frac{\text { surface datum, in feet }}{\text { Before After High Low }}$

Tota 1 range

Bay Co.

17N 4E 22-1 Pinconning

Township

110

Ps

$5.35 \quad 5.35$

$5.17 \quad 5.53$

0.36

Calhoun Co.

1S $7 \mathrm{~W} 32-3$

$2 \mathrm{~S} 8 \mathrm{~W} \quad 2-1$

$$
\begin{aligned}
& \text { Penfield Town- } \\
& \text { ship } \\
& \text { oliver Electric } \\
& \text { Mfg. Co. }
\end{aligned}
$$

Clinton Co. 5N 2W 31-1

Mich. Dept. of Aeronautics

De1ta Co.

39N 23W 28-3 M \& S Blake

Eaton Co.

3N 3W 2-1

$4 \mathrm{~N} \quad 4 \mathrm{~W} \quad 11-1$

$4 \mathrm{~N} \quad 4 \mathrm{~W} \quad 2-1$

$\begin{array}{lll}4 \mathrm{~N} & 3 \mathrm{~W} & 12-1\end{array}$

Genesee Co.

7N 7E 17-1

$7 \mathrm{~N} 7 \mathrm{E} \quad 17-1$

Gogebic Co. 48N 47W 34-2 48N 47W 34-3

$48 \mathrm{~N} \quad 47 \mathrm{~W} 31-1$

Ingham Co. $4 \mathrm{~N} 2 \mathrm{~W} \mathrm{24-1}$

$4 \mathrm{~N}$ 1W 27-1

$4 \mathrm{~N}$ 1W 27-1

$4 \mathrm{~N}$ 1E 21-1

$3 \mathrm{~N} 2 \mathrm{~W} 23-2$

2N $1 W$ 5-2

Do.

\section{City of Lansing \\ City of Grand Ledge Do. \\ F. A. Wheeler
Consumers Power Company 95

92

Mm

25.00

25.00

$23.73 \quad 26.01$

Mm

15.25

15.25

$14.24 \quad 15.81$

1.27
530

Ps

$61.22 \quad 61.22$

$61.06 \quad 61.41$

0.35

2.22

$\mathrm{Cm}$

2.94

2.94

1.82

4.04

$3.83 \quad 4.19$

0.36

350

376

381

$\begin{array}{lrr}\text { Qgd } & 4.04 & 4.04 \\ & & \\ \text { Ps } & 2.51 & 2.51 \\ \text { Ps } & 29.77 & 29.77 \\ \text { Ps } & 81.88 & 81.88\end{array}$

2.35

2.62

0.27

$29.765 \quad 29.78$

$81.46 \quad 82.34$

0.015

0.86

$\begin{array}{llllll}\text { Ps } & 25.68 & 25.68 & \mathrm{a}_{24.68} & \mathrm{a}_{26.68} & \mathrm{a}_{+2} .00 \\ \text { Ps } & 25.67 & 25.67 & \mathrm{~b}_{25.23} & \mathrm{~b}_{26.16} & \mathrm{~b}_{0.93}\end{array}$

City of Ironwood 35

Do.

22

115 $\begin{array}{lll}\text { Qgd } & 0.71 & 0.69 \\ \text { Qgd } & 3.04 & 3.04\end{array}$

Qgd $22.40 \quad 22.40$

Mich. State Univ. 453

Do.

278

Do.

278

Duncan Lumber Co. 265

Delhi Township 268

City of Mason

210

$\begin{array}{lcc}\text { Ps } & 65.10 & 65.10 \\ \text { Ps } & 6.85 & 6.85 \\ \text { Ps } & 6.86 & 6.86 \\ \text { Ps } & 21.525 & 21.525 \\ \text { Ps } & 7.33 & 7.33 \\ \text { Ps } & 22.50 & 22.50\end{array}$

64.18

a7.35

$\mathrm{b}_{6} .83$

21.47

a. 6.83

22.31
0.0

2.16

1.35

3.78

22.98

65.92

a 6.35

b6.88

21.58

a 7.83

22.685
1.35

1.62

1.18

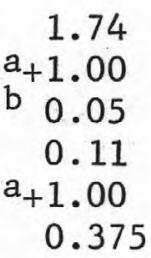


Table 1.--Fluctuations of water levels in some Michigan observation we11s in response to the great Alaskan earthquake.--Continued

\section{County}

and

We11 No.

Presque Isle

\section{Co.}

$33 \overline{\mathrm{N}} 6 \mathrm{E} \quad 15-1$

H. Ennest

31

Dt

6.90

6.90

6.45

7.35

0.90

Schoolcraft

Co.

$47 \overline{\mathrm{N}} 16 \mathrm{~W} 30-1$ Mich. Dept. of Conservation
We11 *Chief Depth to water below land

Depth aqui-

(feet)

fer

$\frac{\text { surface datum, in feet }}{\text { Before After High Low }}$

Tota 1

range

$\begin{array}{lllllll}57 & \text { Op } & 15.45 & 15.45 & 15.38 & 15.53 & 0.15\end{array}$

Van Buren

Co.

$4 \mathrm{~S} \frac{\mathrm{Co}}{16 \mathrm{~W}} 22-1 \quad$ Frigid Foods Co. $134 \quad$ Qgd $27.46 \quad 27.46 \quad 27.455 \quad 27.465 \quad 0.01$

Washtenaw Co.

3S 6E 16-3 City of Ann

3S 7 E 5-1 City of Ypsi-

lanti

Do.

3S $7 \mathrm{E} \quad 9-3$

3S $7 \mathrm{E} \quad 24-6$

Federa 1 Works Agency

$\begin{array}{rrrrrrr}55 & \text { Qgd } & e_{12} .50 & e_{12} .50 & e_{12} .15 & e_{12.85} & e_{0.70} \\ 69 & \text { Qgd } & 3.34 & 3.34 & 3.28 & 3.39 & 0.11 \\ 94 & \text { Qgd } & 66.34 & 66.34 & 66.29 & 66.41 & 0.12 \\ 75 & \text { Qgd } & 33.51 & 33.51 & 33.20 & 34.37 & 1.17\end{array}$

Wayne Co.

1S $8 \mathrm{E} \mathrm{17-1}$ City of Plymouth

114

Qgd $\quad 53.90$

53.90

53.32

54.49

1.17

Wexford Co. 21N 9W 4-1

a Ink line completely around chart on drum. Fu11 amplitude greater than shown

b Aftershock $1 / 2$ hour later

c Aftershock 13 hours later

e estimated

*Chief Aquifer: Qgd - Glacial drift deposits of Pleistocene (Quaternary) age

Ps - Saginaw Formation of Pennsylvanian age

Mm - Marsha11 Formation of Mississippian age

Dt - Traverse Group of Middle and Late Devonian age

Sm - Manistique Dolomite of Middle Silurian age

Op - Prairie du Chien Group of Early Ordovician age (previously designated as Au Train Formation)

$\mathrm{Cm} \quad$ - Munising Sandstone of Cambrian age 

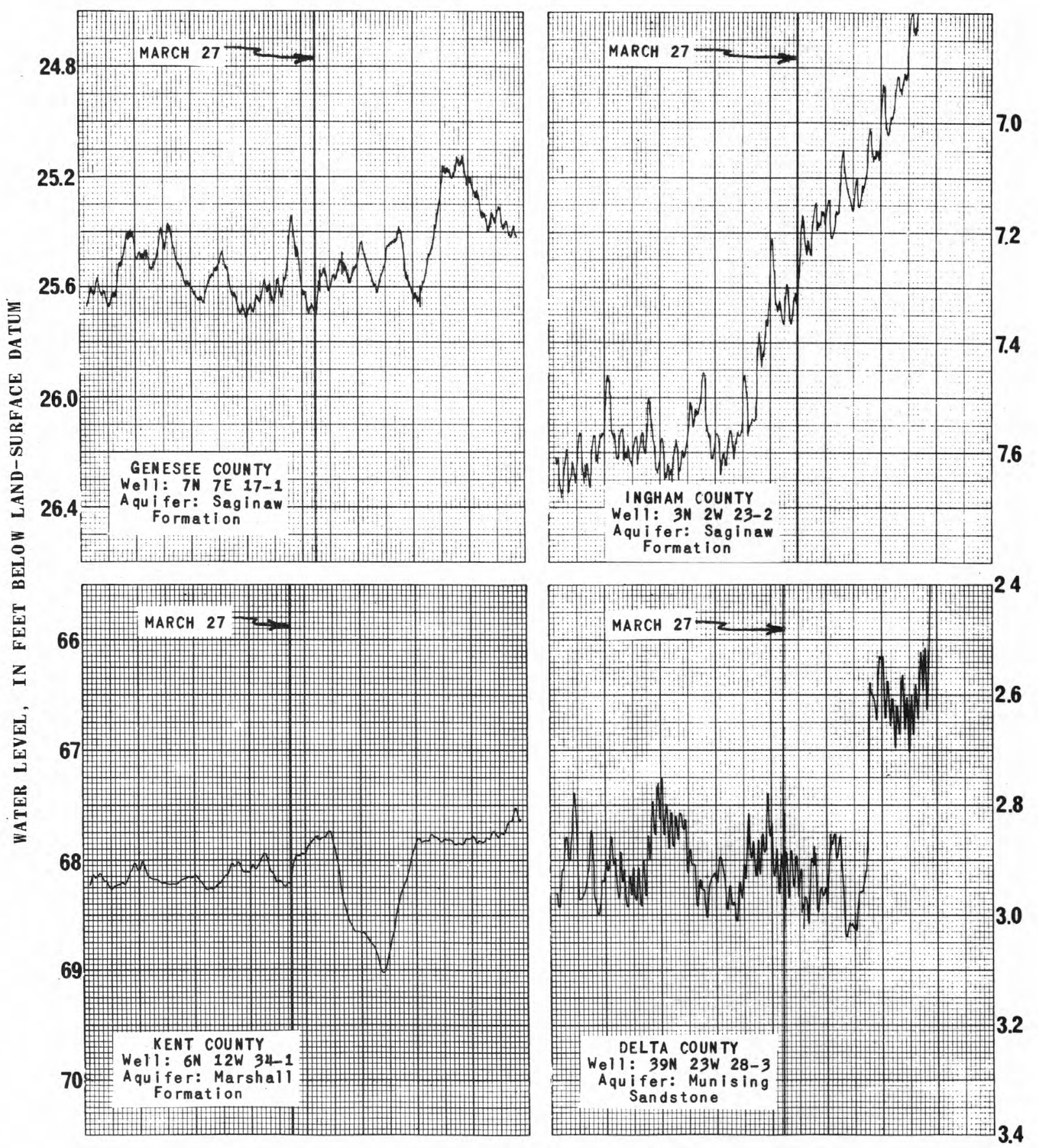

FIGURE 6.--RECORDER CHARTS SHOWING FLUCTUATION OF WATER LEVELS IN FOUR WELLS AS A RESULT OF THE MARCH 27 (GOOD FRIDAY) ALASKAN EARTHQUAKE.

In each of these wells the fluctuations exceeded the total circumference of the chart and ranged from over a foot to more than five feet. 
in Michigan. The total vertical double amplitude of fluctuations as recorded ranged from as little as 0.01 of a foot to over 5.00 feet. The apparent time of the fluctuations in Michigan wells was about an hour after the time of occurrence of the earthquake in Alaska. A few wells also recorded aftershocks from this same series of quakes.

The four charts from recording gages (fig. 6) are examples of the fluctuations that occurred as a result of the Alaskan earthquake. The fluctuations exceeded the circumference of the charts on the recording drum so that the exact amount of rise and fall is not known.

\section{Changes in storage from pumping influences}

In areas where ground water is used for municipa1 or industrial supplies, hydrographs of water levels in observation wells show the relation between discharge from wells and natural, induced, and artificial recharge to aquifers. Declines, except as caused by precipitation deficiencies, generally indicate depletion of storage in the aquifers caused by pumping. An effective method of determining the amount of water available from an aquifer is the analysis of long-term records of water levels and pumpage.

Many of the water-level records in pumped areas are obtained by means of continuous recorders. These recording stations provide for the continuous collection of basic water-level data, which serve to indicate both the day-today and also the long-term effects of pumping. This information can be used by municipalities, industries, institutions or their consultants to estimate the capacity of aquifers to meet present and future demands for water, to determine the desirable separation between we11s, and whether expansion of present groundwater supply systems is practicable.

In 1964 many record and near-record lows of water levels were recorded in the heavily-pumped areas of the State. Large deficiencies of precipitation contributed to these record lows, but some of the decline was caused by increased pumpage in the areas. Increasing population, industrial growth and modern water uses create large additional demands for water. These demands for additional water result in increased pumping and lowered water levels and often in need for expansion of water supply facilities. In one sense, water supply problems are a general symptom of a healthy growing community.

Examples of drawdown effects on water levels of nearby pumping are shown by recorder charts C and D (fig. 5). The vertical lines represent 8-hour time intervals. 

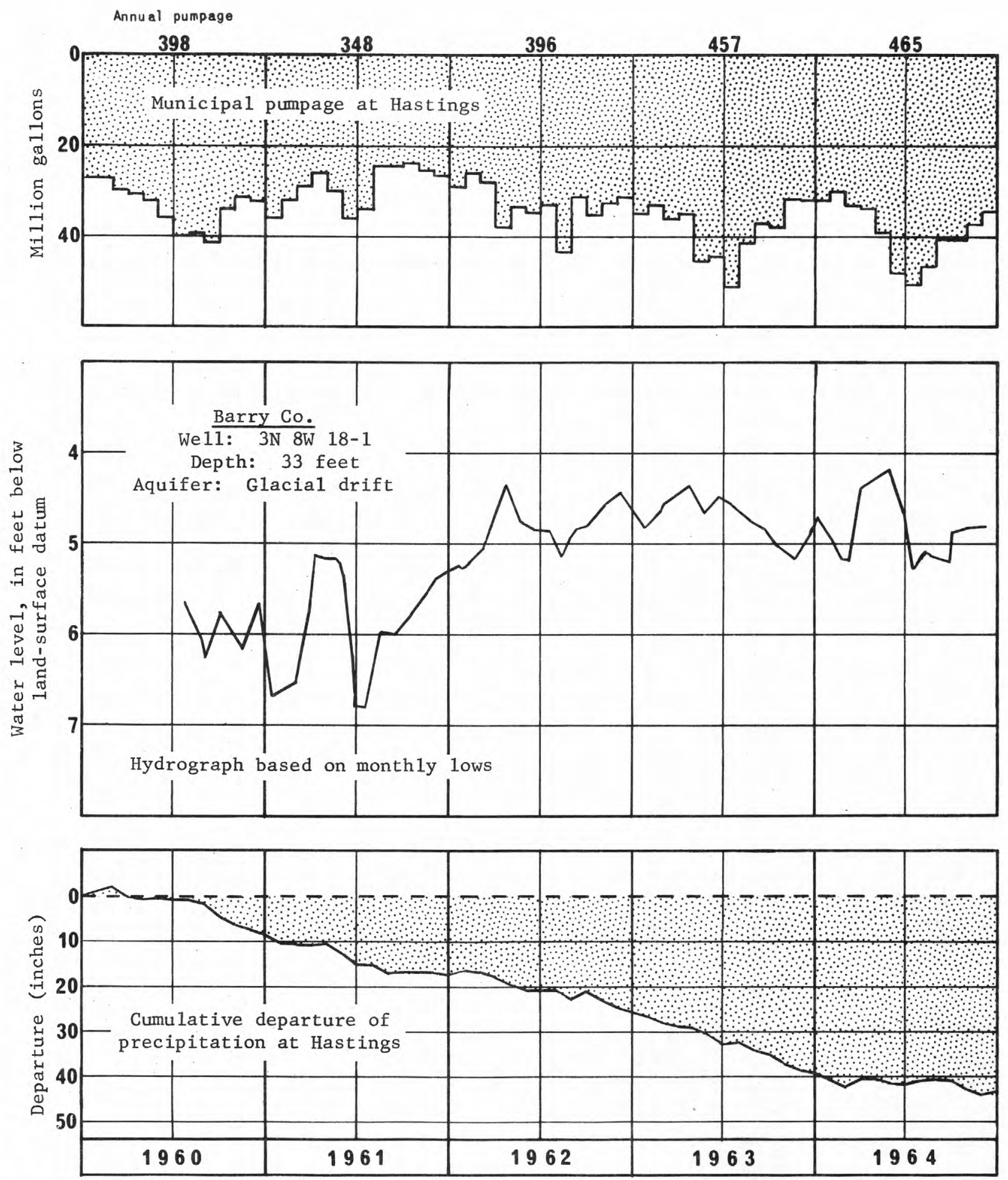

FIGURE 7.--GRAPH OF WATER LEVELS IN A WELL, PUMPAGE, AND PRECIPITATION AT HASTINGS, 1960-64.

Water levels in this well are higher since mid-1961 because of decreased pumpage from the drift aquifer and despite the deficiency of precipitation. 
Water supply -- Four wells -- nos. $2 \& 3$, about 55 feet deep, are finished in glacial drift; no. 1 is 339 feet and no. 4 is 350 feet deep and tap sandstones of the Marshall Formation.

Yield of wells in gallons per minute -- No. $1-1,525 ;$ nos. $2 \& 3-750 ;$ no. 4 1,725 .

Specific capacity of wells in gallons per minute per foot of drawdown -No. 1 - 25 ; nos. $2 \& 3-58$; no. 4 - 100 .

Pumpage in $1964--465$ million ga11ons.

Maximum day -- 2.56 million gallons.

Storage facilities -- 550,000 gallons elevated (S. Tank - 300,000; N. Tank $250,000)$.

Quality of water -- Drift we11s have hardness of 325-340 ppm and iron 0.0-0.2 ppm. Rock we11s have hardness of $280 \mathrm{ppm}$ and iron $0.4 \mathrm{ppm}$.

Treatment -- Fluoridation.

Population served -- 6,375.

Per capita use -- 199 gallons per day.

Ground-water conditions -- Water levels in the glacial drift observation we 11 remained high in 1964 despite continued deficiencies of precipitation amounting to over 43 inches for the 1960-64 period (fig. 7). The higher levels in the drift aquifer are the result of large use (90\%) of water from the Marshal1 Formation since 1961 with a corresponding decrease in use of water from the drift. Artesian pressures in the Marshal1 are above land surface at Hastings. However, no observation we11 is available at this time to gage the levels or observe the effects of withdrawals of water locally from the Marsha11. 


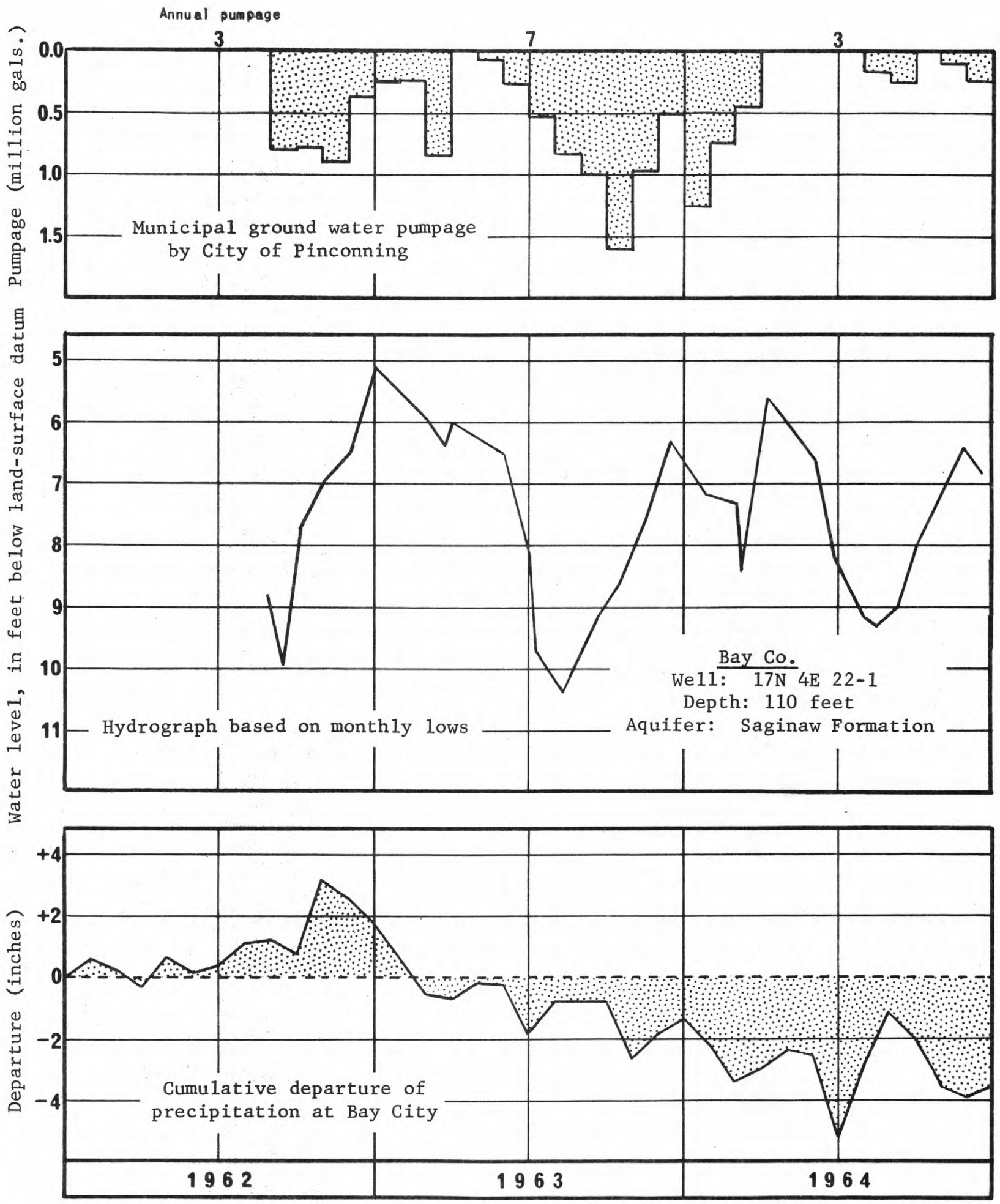

FIGURE 8 ---GRAPHS SHOWING WATER LEVELS IN A WELL IN PINCONNING TOWNSHIP, PUMPAGE AT PINCONNING, AND PRECIPITATION, 1962-64.

Precipitation variations influence the water levels more than the sma11 amount of pumpage by the City of Pinconning. 
Water supply -- The only public supply in the Township is at the City of Pinconning. Water is obtained from Saginaw Bay, supplemented by a we11, 110 feet deep, tapping sandstones of the Saginaw Formation.

Yield of we1ls in gallons per minute -- 70 .

Specific capacity of wells in gallons per minute per foot of drawdown -- 1.1.

Pumpage in 1964 -- 3.15 million gallons from a we11.* 76.52 million gallons from the Bay (*About $2 \%$ of the Bay water is used for back flushing filters.)

Storage facilities -- 75,000 gallons elevated.

Quality of water -- Saginaw Bay: Hardness 125 ppm Well water: Hardness 650 ppm Iron $0 \mathrm{ppm} \quad$ Chloride 60Chloride $25 \mathrm{ppm} \quad 106 \mathrm{ppm}$

Treatment -- Standard Filtration.

Population served -- 1,324.

Per capita use -- 162 gallons per day.

Ground-water conditions -- Records of ground-water leve1s in the area were continued in 1964 by the maintenance of a continuous recorder on a we11 in Pinconning Township. The light pumpage by the City appears to have less effect on the levels in the observation well than precipitation. Levels were highest at the end of 1962 when precipitation was above average. The subsequent overall deficiency of about 6 inches in the 1963-64 period resulted in a decline of two feet in water level at the end of 1964 as compared to the end of 1962 (fig. 8). 


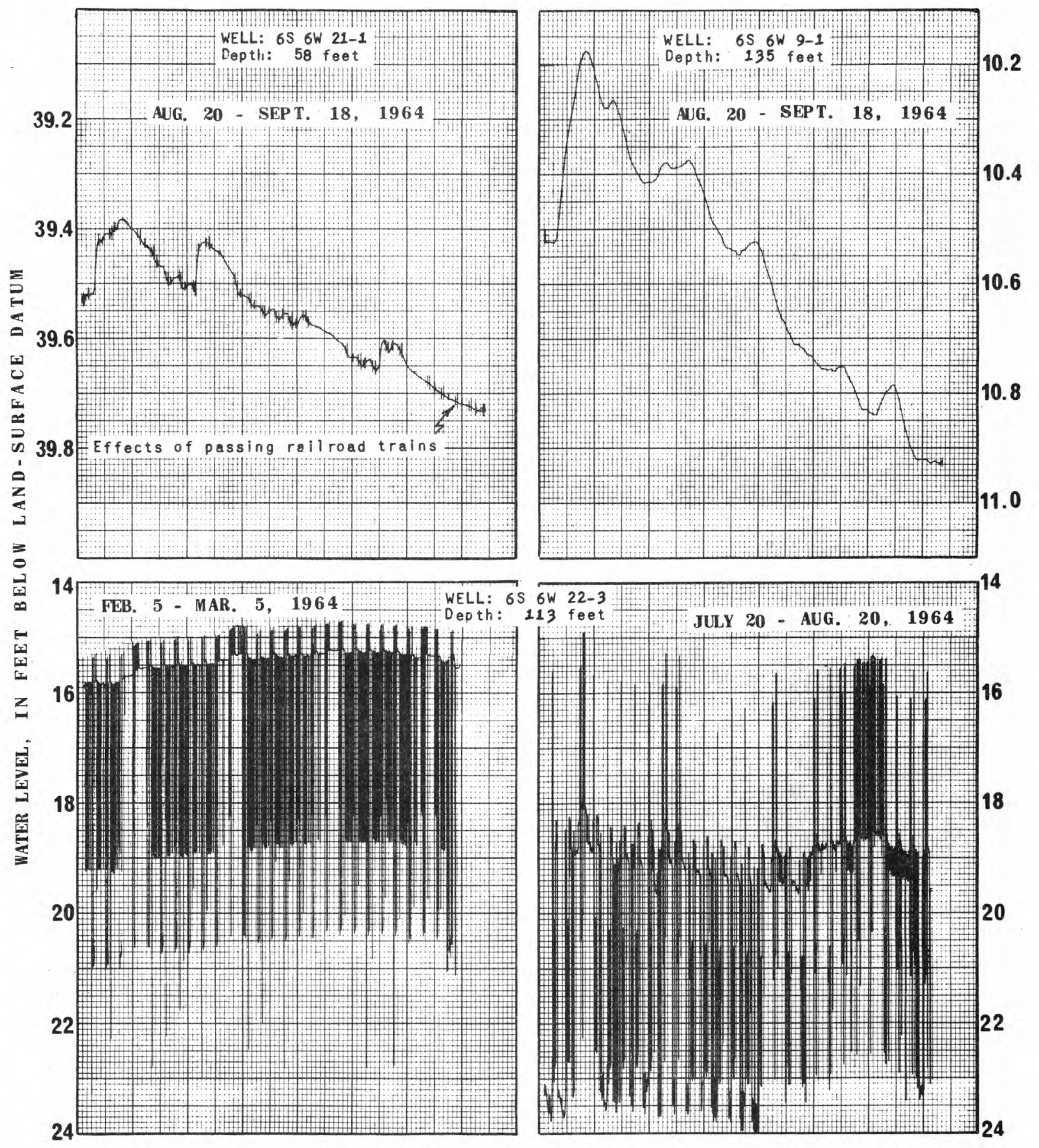

FIGURE 9.--RECORDER CHARTS SHOWING CHANGES IN WATER LEVELS IN THREE WELLS IN AND NEAR COLDWATER IN BRANCH COUNTY.

The upper two charts show the general decline of water levels during the growing season. The lower two charts show the effects of nearby pumping of municipal wells at the Coldwater we11 field. 
BRANCH COUNTY - CITY OF COLDWATER

Water supply -- Three we1ls in 1964 finished in glacial drift 121-132 feet deep.

Yield of wells in gallons per minute -- No. $3-1,200$; no. $4-1,400$; no. 5 2,250 .

Specific capacity of wells in gallons per minute per foot of drawdown -- No. 3 235 ; no. 4 - 160 ; no. 5 - 150 .

Pumpage in 1964 -- 918 million ga11ons.

Maximum day -- 5.37 million gallons.

Storage facilities -- 300,000 gallons elevated.

Qua1ity of water -- Hardness 175-295 parts per million

Iron $\quad 1.1-1.5$ parts per million

Treatment -- Chlorination, calgon and phosphate for iron treatment.

Population served -- estimated 9,000.

Per capita use -- 280 gallons per day.

Ground-water conditions -- A 2-year study of the water resources of Branch County in cooperation with the county and the Michigan Department of Conservation was begun in 1964 with completion due in June, 1966. Some 29 observation wells, 3 of which were equipped with recording gages, were measured in 1964. Four recorder charts (about $1 / 3$ actual size) from these three recording gages are shown in figure 9. The graphs show typical water-level fluctuations in these three wells. The two upper charts show the general summer decline, the effects of distant pumpage on water levels and weekly rises indicating decreased area pumpage during weekends. The small vertical fluctuations in chart of we11 21-1 are the results of compressional loading on the aquifer by passing railroad trains. The two lower charts are from the observation we 11 located at the City of Coldwater's well field. Here, the water levels fluctuate sharply from the effects of heavy pumping by three wells varying from about 10 feet to about 500 feet from the observation we11. It is interesting to note the effects of pumping of one or combinations of the three pumping wells and also the difference in average pumping level in the summer and winter seasons. The municipal we11s are among the highest producers in the State. 

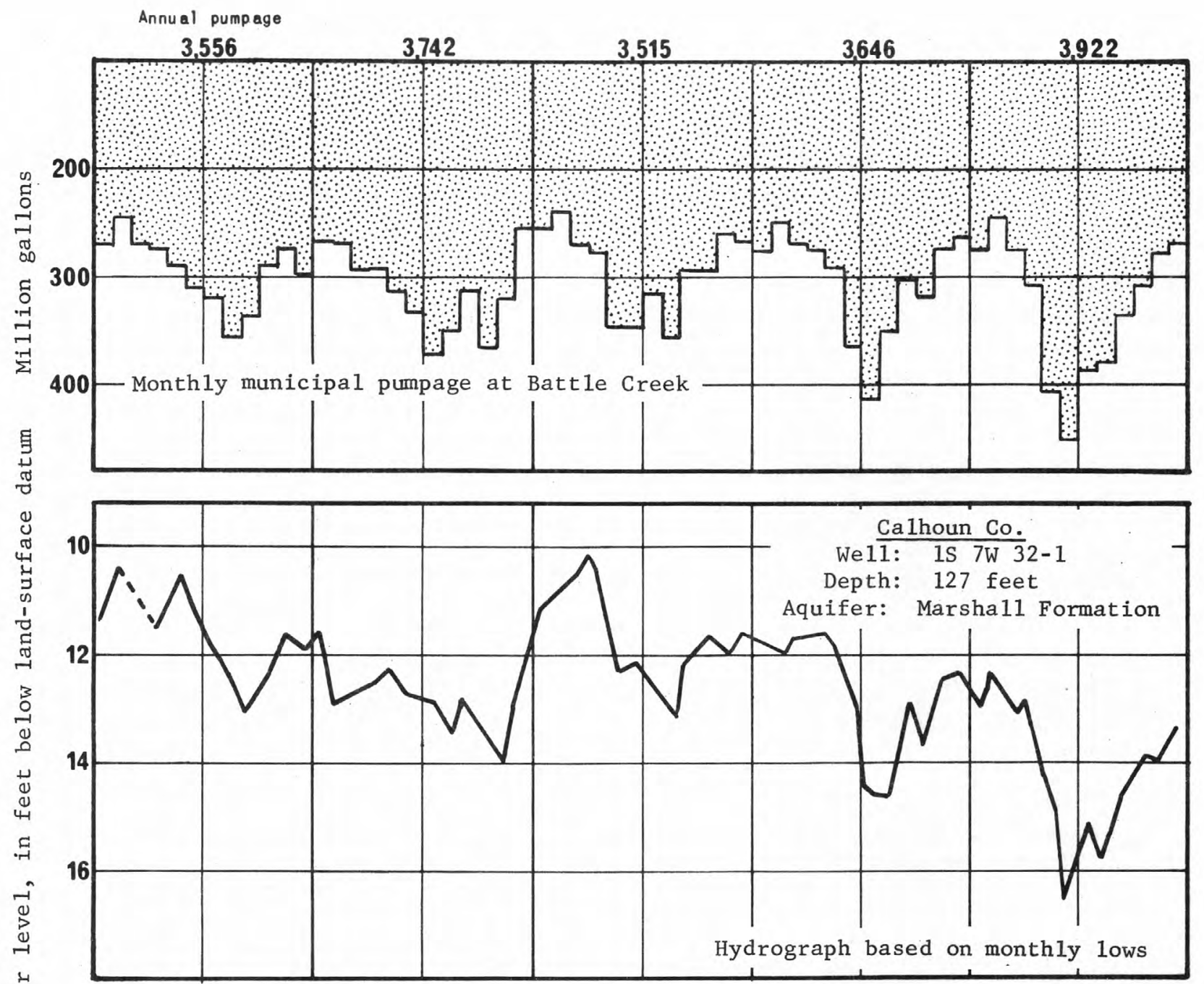

盛

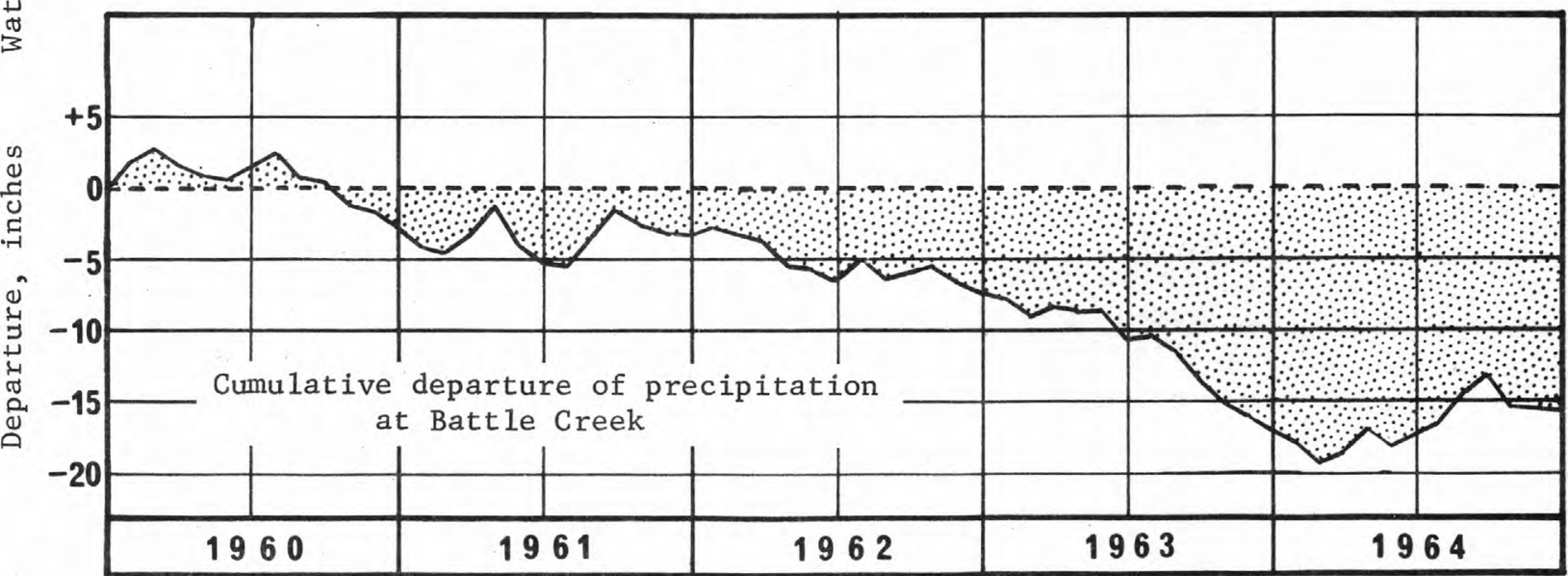

FIGURE 10.--GRAPHS SHOWING WATER LEVELS IN A WELL AT VERONA STATION, PUMPAGE AND PRECIPITATION, AT BATTLE CREEK, 1960-64。

Despite above-average precipitation in 1964 water levels fel1 as pumpage was increased. 


\section{CALHOUN COUNTY - CITY OF BATTLE CREEK}

Water supply -- About 29 wells, 120-160 feet deep, are located at the Verona field and tap sandstones of the Marshall Formation. A few standby wells finished in glacial drift at depths of about 82-163 feet are located at the Goguac well field. These wells are seldom used.

Yield of we11s in gallons per minute -- 300-1,000.

Specific capacity of we11s in gallons per minute per foot of drawdown -- 50-650.

Pumpage in $1964--3,922$ mi11ion ga11ons.

Maximum day -- 21.10 million gallons.

Storage facilities -- 200,000 gallons at Plant; 4,100,000 gallons elevated.

Quality of water -- Composites of Verona wells - Hardness 240-285 ppm Iron $\quad 0.05-5.0 \mathrm{ppm}$

Treatment -- Chlorination, fluoridation.

Population served -- 44, 169.

Per capita use -- 243 gallons per day.

Ground-water conditions -- Despite above-normal precipitation in 1964 water levels in the observation well fell to near-record low at mid-year as the result of increased municipal pumpage (fig. 10). The lowest water levels were previously recorded in 1959 when a record 4.37 billion gallons of water were pumped from the Verona field.

Considering the amount of water being pumped, water levels are still high, and no serious dewatering has occurred at this field. The Verona field wells are collectively the most prolific in the State. 

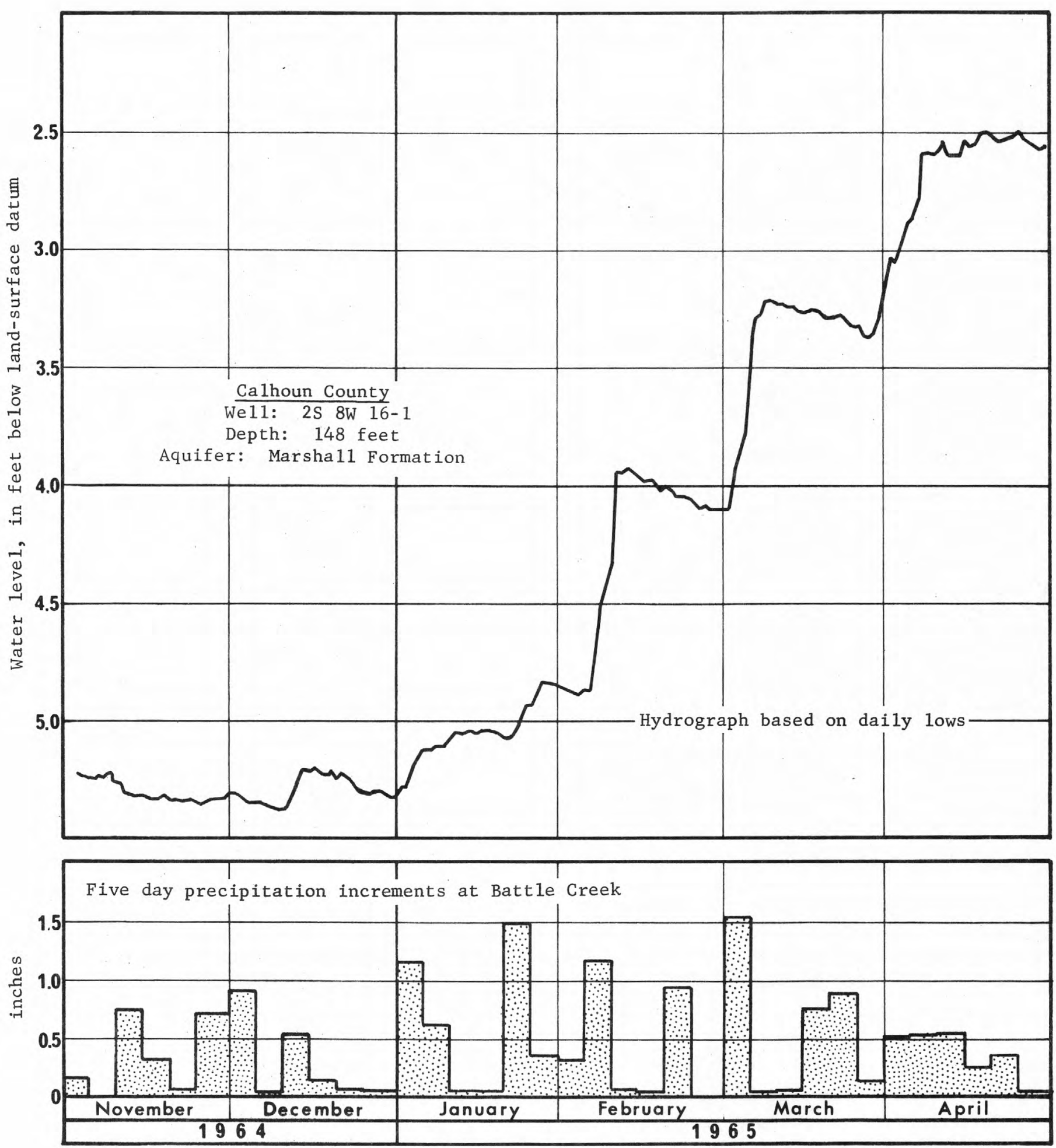

FIGURE 11.--GRAPH SHOWING WATER LEVELS IN A WELL IN BATTLE CREEK TOWNSHIP, AND PRECIPITATION, NOVEMBER 1964 THROUGH APRIL 1965.

The water levels in this observation we11 show the natural climatic effects prior to the start of pumping in this new Township well field. 
Water supply -- Four we11s, 143-165 feet deep, tap sandstones of the Marsha11 Formation.

Yield of wells in gallons per minute -- 950 .

Specific capacity of wells in gallons per minute per foot of drawdown -- 10-20.

Pumpage in 1964 -- 375 million ga11ons.

Maximum day -- 3.06 million gallons.

Storage facilities -- 400,000 gallons elevated storage.

Quality of water -- Hardness 280-350 ppm Iron $\quad 0.5-1.2 \mathrm{ppm}$

Treatment -- Chlorination.

Population served -- estimated 13,500.

Per capita use -- 76 gallons per day.

Ground-water conditions -- A water-leve1 recording station was established on a well at a new well field for Battle Creek Township in November of 1964. The hydrograph (fig. 11) shows the effects of natural climatic conditions on the water levels. Although two municipal production wells have been installed they are not yet (1964) in operation. Levels are high and the effects of recharge from precipitation and snowmelt in late March and early April are reflected in rises of water levels in the observation we11. Pumpage at this field is to begin in early 1965 from two new wells reportedly yielding about $1,000 \mathrm{gpm}$ each. 

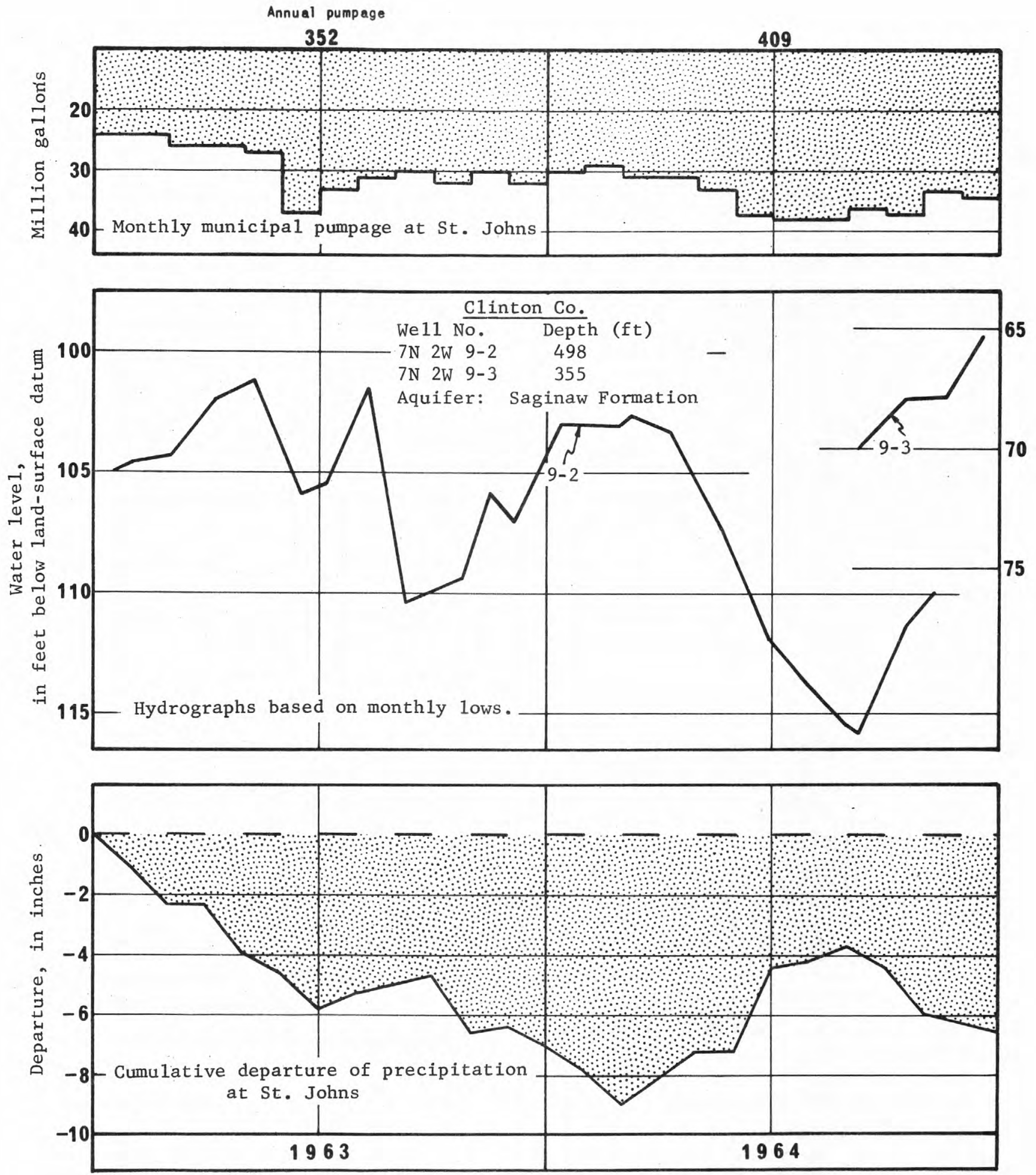

FIGURE 12.--GRAPHS SHOWING WATER LEVELS IN TWO WELLS, PUMPAGE AND PRECIPITATION, ST. JOHNS, 1963-64.

We11 9-3 replaced 9-2 in 1964 because the latter well was too close to pumping we11s. 


\section{CLINTON COUNTY - CITY OF ST. JOHNS}

Water supply -- Four we11s, about 500 feet deep, tapping sandstones of the Saginaw Formation.

Yield of wells in gallons per minute -- reportedly average 900.

Specific capacity of wells in gallons per minute per foot of drawdown -- 3-5.

Pumpage in 1964 -- 409 million gallons.

Maximum day -- 1.57 million gallons.

Storage facilities -- 100,000 gallons elevated storage (not used in 1964).

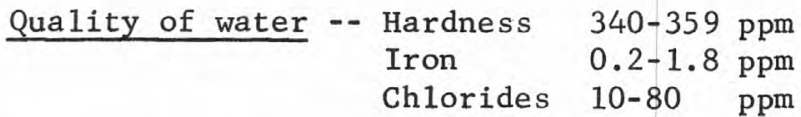

Treatment -- None in 1964.

Population served -- 6,000.

Per capita use -- 187 gallons per day.

Ground-water conditions -- Levels in observation wel1 9-2, located at the City well field, fell in 1964 as the result of a $14 \%$ increase in pumpage and despite above-normal precipitation (fig. 12). Because of the large fluctuation range of from about 67 to 115 feet at this site (table 2, Clinton County), the recorder was moved to another well site about onehalf mile to the north in late 1964. Here the range of fluctuation was only about 15 feet in late 1964 (table 2).

As the result of a study by a private consultant, 2 test we 11 s were drilled in 1964 and 2 production we11s were installed about $1 / 3 \mathrm{mile}$ from the present we11 field to take advantage of higher water levels, and less pumping lift, than at the present well field. 


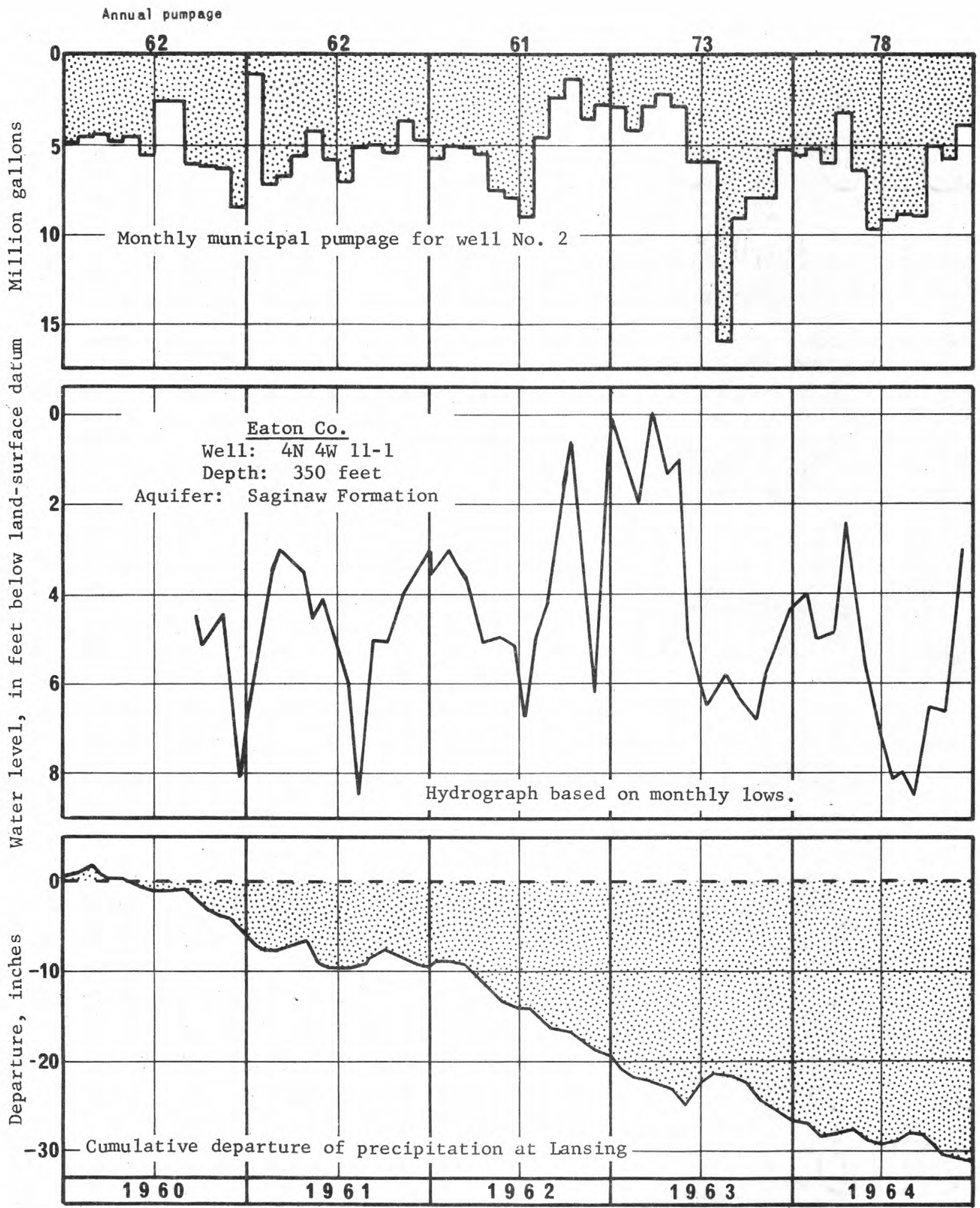

FIGURE 13.--GRAPHS OF WATER LEVELS, PUMPAGE, AND PRECIPITATION, GRAND LEDGE, 1960-64.

No significant decline has occurred despite deficient precipitation. 
Water supply -- Three we11s, nos. 2, 3, and 4, 241-400 feet deep, in sandstones of the Saginaw Formation.

Yield of wells in gallons per minute -- 300-525.

Specific capacity of wells in gallons per minute per foot of drawdown -- 3.5-10.

Pumpage in 1964 -- 161 million gallons.

Maximum day -- 0.94 million gallons.

Storage facilities -- 100,000 gallons elevated.

Quality of water -- Hardness 364-405 ppm

Iron $0.5-2.0 \mathrm{ppm}$

Fluoride $0.2-0.3 \mathrm{ppm}$

Treatment -- Chlorination, phosphate.

Population served -- 5,165.

Per capita use -- 85 gallons per day.

Ground-water conditions -- The observation we11, 11-1, most1y reflects pumpage withdrawals by municipal wel1 no. 2 (fig. 13) about $1 / 3$ mile away. The precipitation deficiency shown in the illustration does not seem to affect the levels in this we11 although a departure of about 31 inches occurred in the 1960-64 period.

The water leve1 in observation we $114 \mathrm{~N} 4 \mathrm{~W} 2-1$ (Eaton County Table 2, Chair Factory Site) about a mile from municipal pumping we11s continued to decline in 1964 and fell to a new record low mostly as a result of deficient precipitation. 


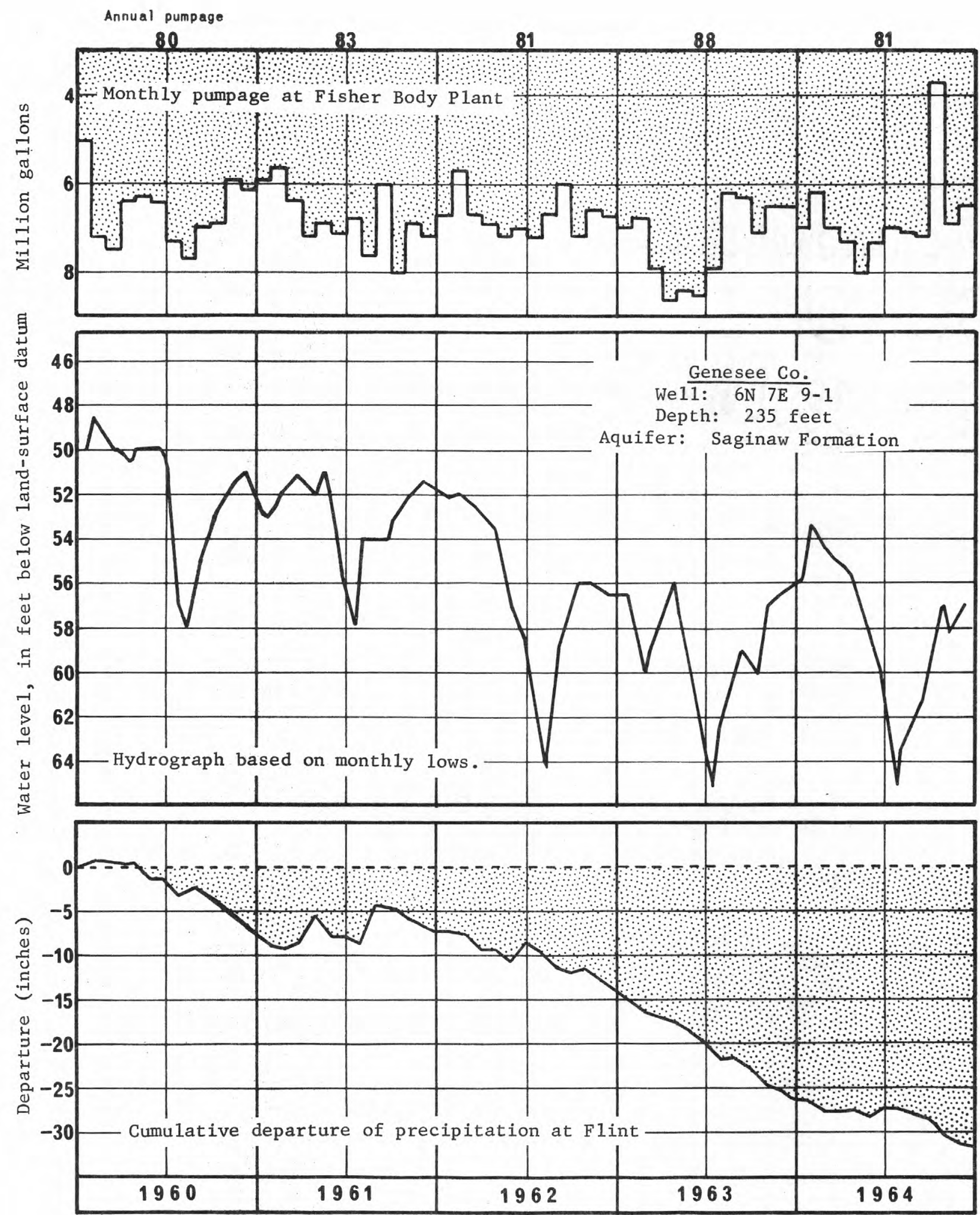

FIGURE 14.--GRAPHS SHOWING WATER LEVELS, PUMPAGE, AND PRECIPITATION AT THE FISHER BODY PLANT NEAR GRAND BLANC, 1960-64.

This area has lost nearly a year's rainfall in this five-year period. 
GENESEE COUNTY - FISHER BODY, GMC, AT GRAND BLANC

Water supply -- Three wells, 200 to 275 feet deep, tap sandstones of the Saginaw Formation.

Yield of we11s in gallons per minute -- 250-300.

Specific capacity of wells in gallons per minute per foot of drawdown -$3-1 / 2$ to $6-2 / 3$.

Pumpage in 1964 -- 81.3 million gallons.

Storage facilities -- Ground and elevated: 100,000 plant 650,000 fire protection

Quality of water -- Hardness 255-344 ppm Chloride 72-120 ppm

Treatment -- Phosphate and chlorination.

Ground-water conditions -- Despite continued deficiencies of precipitation no significant decline has occurred since mid-1962 and levels have remained relatively steady (fig. 14). Average low levels, however, are more than 20 feet below those recorded at the start of the record in the 1952-53 period. 

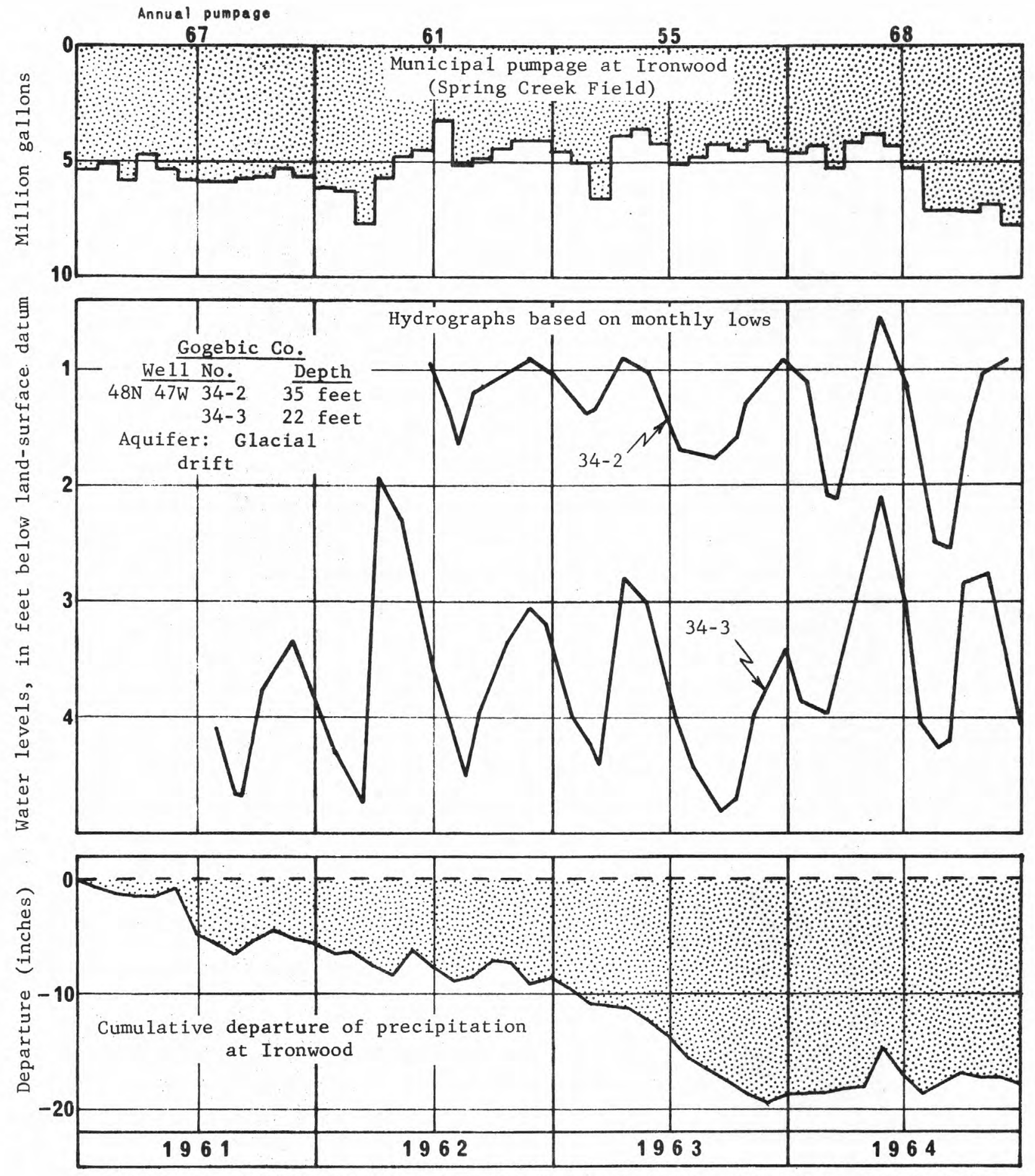

FIGURE 15.--GRAPHS SHOWING WATER LEVELS IN TWO WELLS, PUMPAGE AT SPRING CREEK FIELD, AND PRECIPITATION, IRONWOOD, 1961-64.

Despite deficient precipitation during the 4-year period water levels showed little change. 
Water supply -- Five we11s, 41 to 118 feet deep, finished in glacial drift at Spring Creek and Big Springs fields near Ironwood. No. 1 - 41 feet deep; Nos. 2 and 3 - 118 feet deep; No: 4 - 69 feet deep; and No. 5 47 feet deep. Nos. 1, 3 and 4 are 26-inch diameter and nos. 2 and 5 are 12 -inch.

Yield of wells in gallons per minute -- No. 1 - 380; no. 2 - 135; no. 3 - 360; no. 4 - 200; no. $5-240$.

Specific capacity of we11s in gallons per minute per foot of drawdown -No. 1 - 47; no. 2 - ?; no. 3-21; no. 4-6; no. 5 - 27 .

Pumpage in 1964 -- 316 million gallons. Maximum day -- 1.13 million ga11ons.

Storage facilities -- 1,000,000 gallons ground leve1 on system, and 2,500,000 gallons elevated storage.

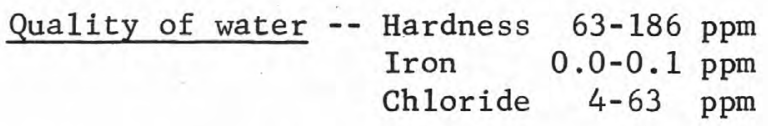

Treatment -- Chlorination.

Population served -- estimated 11,500 .

Per capita use -- 75 gallons per day.

Ground-water conditions -- Levels fell in well 34-2 in response to pumping (fig. 15) by new production well No. 5. An uptrend in levels occurred in we11 34-3 as a result of less pumpage by production we 11 No. 4 . Water-table elevations at this field are high and about the level of Spring Creek. Despite deficient precipitation during the 4-year period no significant change in water levels has occurred.

At the Big Spring Field levels were higher at the end of 1964 than at the end of the previous year principally as a result of about $13 \%$ less pumpage (fig. 16) and the first above-average year of precipitation in 1961-64 period.

Location of well fields, production wells and observation wells is shown in figure 16. 


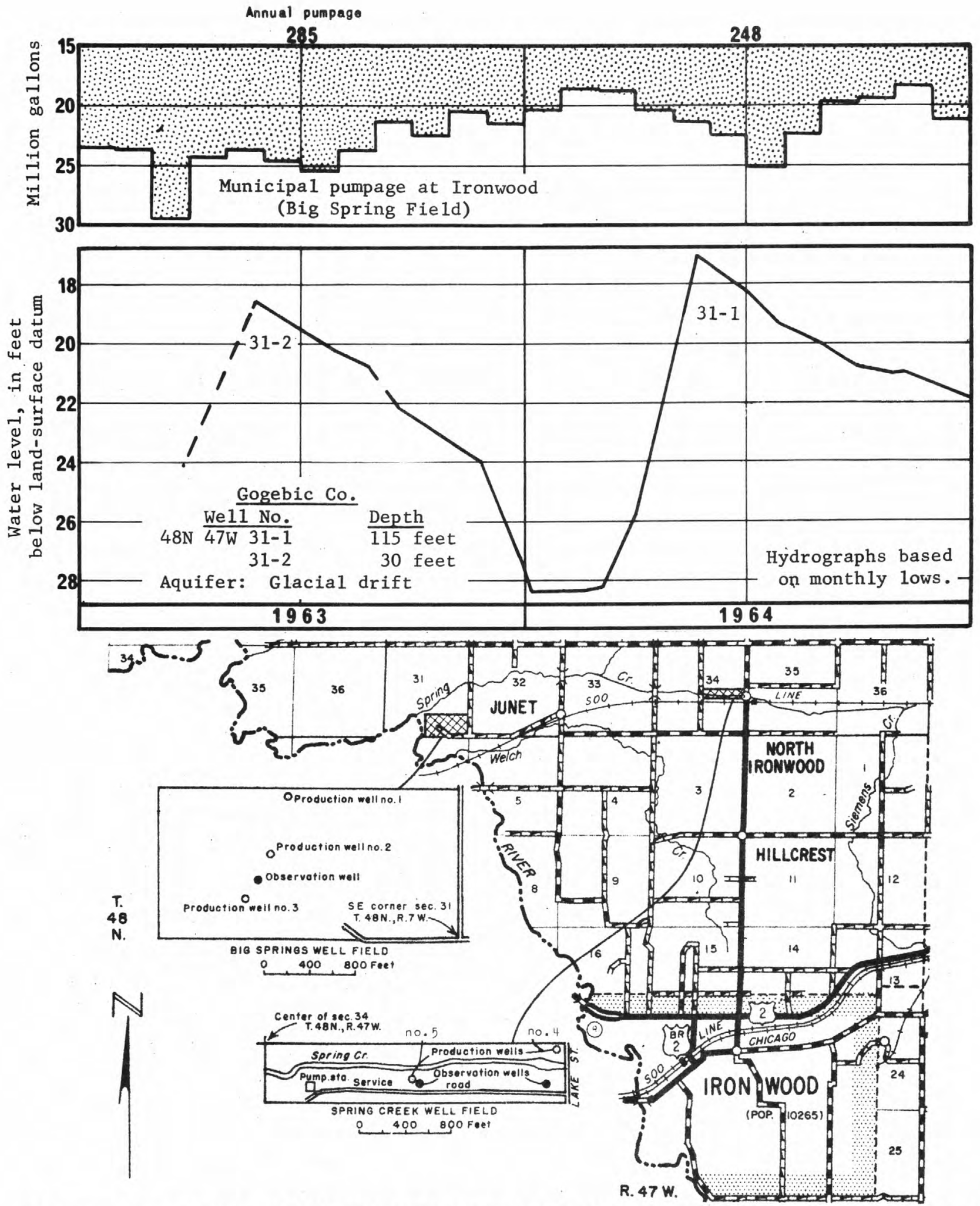

Figure 17 ---GRAPHS SHOWING WATER LEVELS IN TWO WELLS, AND PUMPAGE, IRONWOOD, 1963-64; AND MAP SHOWING LOCATION OF OBSERVATION WELLS AND WELL FIELD.

Water levels in the shallow and deep well are the same. 


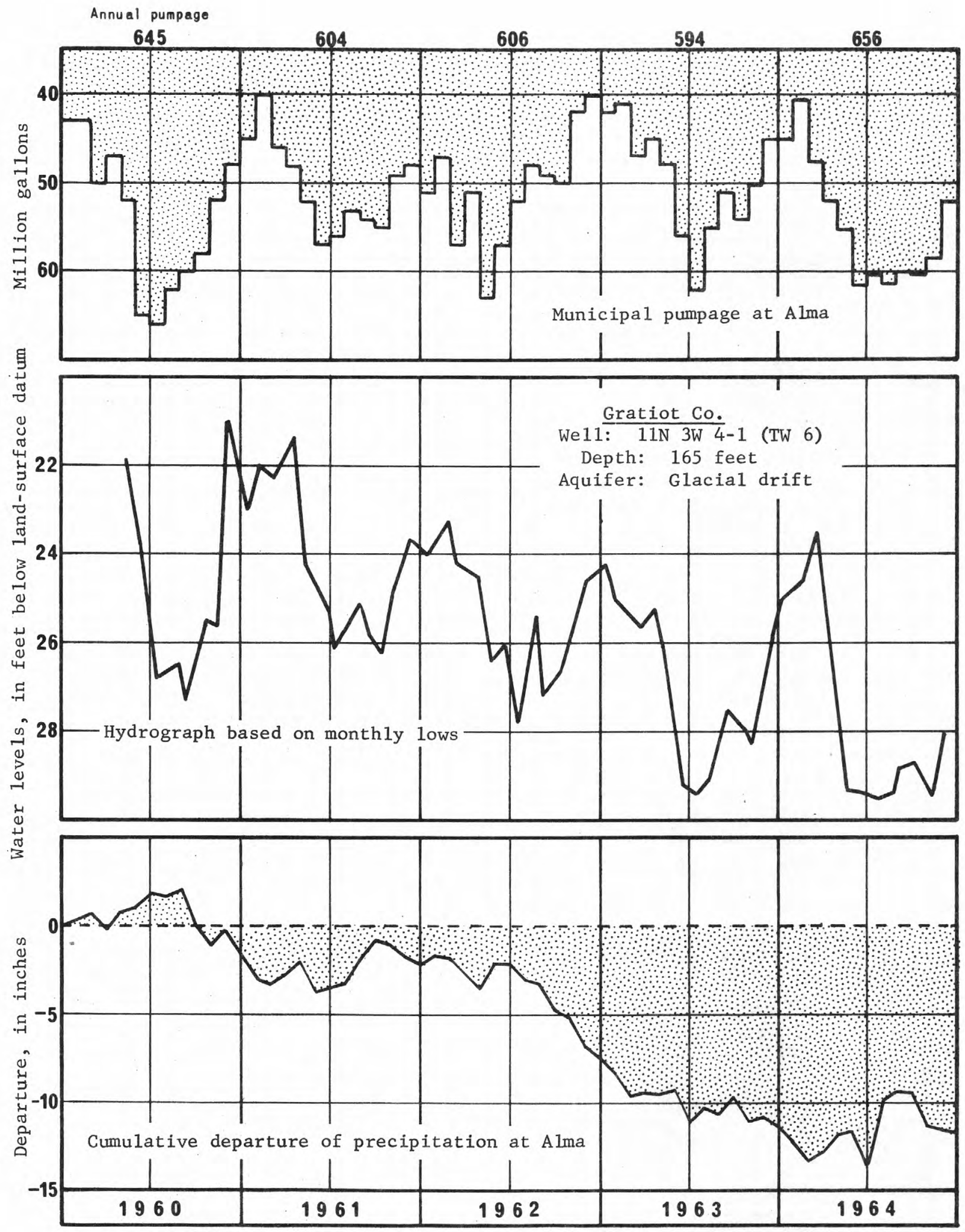

FIGURE 17.--GRAPHS SHOWING WATER LEVELS, PUMPAGE, AND PRECIPITATION, ALMA, 1960-64.

Although pumpage increased in 1964, no further decline occurred as precipitation was not deficient. 
Water supp1y -- Five we11s, 82-155 feet deep, tapping buried outwash deposits of the glacial drift. Standby we11, 550 feet deep, tapping sandstone of the Saginaw Formation.

Yield of wells in gallons per minute -- 175-875.

Specific capacity of we11s in ga11ons per minute per foot of drawdown --

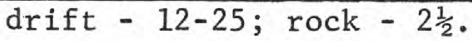

Pumpage in 1964 -- 656 million gallons. Maximum day -- 2.74 million gallons.

Storage facilities -- 1,000,000 gallons elevated.

Quality of water -- Drift: Hardness 350-451 ppm

Iron $\quad 1.4-1.7 \mathrm{ppm}$

Rock we11: Hardness $250 \mathrm{ppm}$

Fluoride $0.1-0.2 \mathrm{ppm}$

Iron $\quad 1.1 \mathrm{ppm}$ Fluoride $0.1 \mathrm{ppm}$

Treatment -- None.

Population served -- 8,978.

Per capita use -- 200 gallons per day.

Ground-water conditions -- Despite above-normal precipitation levels were genera11y lower in 1964 as pumpage increased $10 \%$ over 1963 (fig. 17). The city (1964) is building a treatment plant to allow use of water from the Pine River. However, wells will supplement the river supply -cooling the warm river water in the summer and warming it in the winter. This plant is due to start operation in 1965. Some of the wells will supply raw water directly to local industries. 


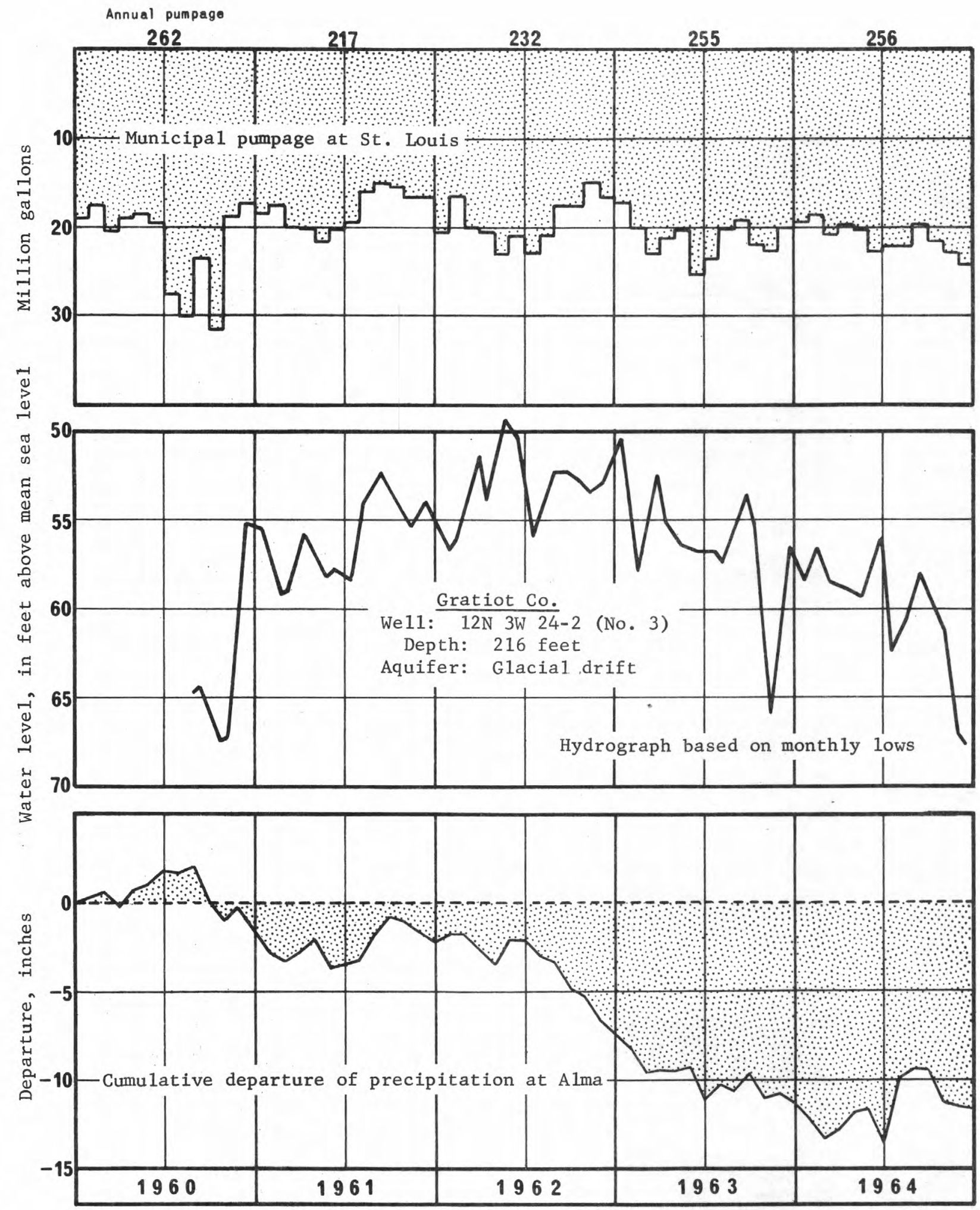

FIGURE 18.--GRAPHS SHOWING WATER LEVELS, PUMPAGE, AND PRECIPITATION, ST. LOUIS, 1960-64.

Deficient precipitation and increased pumpage since 1961 has resulted in a declining trend of water levels. 
Water supply -- Five we11s, 136-223 feet deep, tapping buried outwash deposits of the glacial drift.

Yield of wells in gallons per minute -- 340-540 -- No. 1 - 480; no. 2 - 550; no. $4-400 ;$ no. $5-360$; no. $6-350$.

Specific capacity of wells in gallons per minute per foot of drawdown -- No. 1 11 ; no. 2 - 15; no. 4 - 10; no. 5 - 13; no. $6-8$.

Pumpage in 1964 -- 256 million gallons. Maximum day -- 1.21 million gallons.

Storage facilities -- Hydropneumatic storage of 9,800 gallons; 500,000 ga11ons elevated.

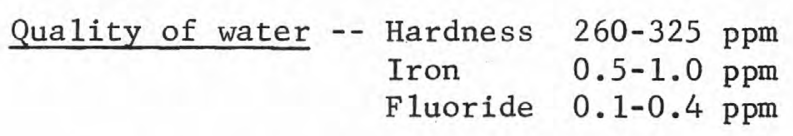

Treatment -- None.

Population served -- 4,000.

Per capita use -- 175 gallons per day.

Ground-water conditions -- Levels in the observation well continued to decline in 1964 despite slightly above-average precipitation in that year (fig. 18). Heavier than average pumpage occurred late in 1964 and levels fe11 to nearly as low as the previous low that occurred in 1960. In addition to the municipal pumpage, ground water is also withdrawn for industrial use by two wells at the Michigan Chemical Company. 

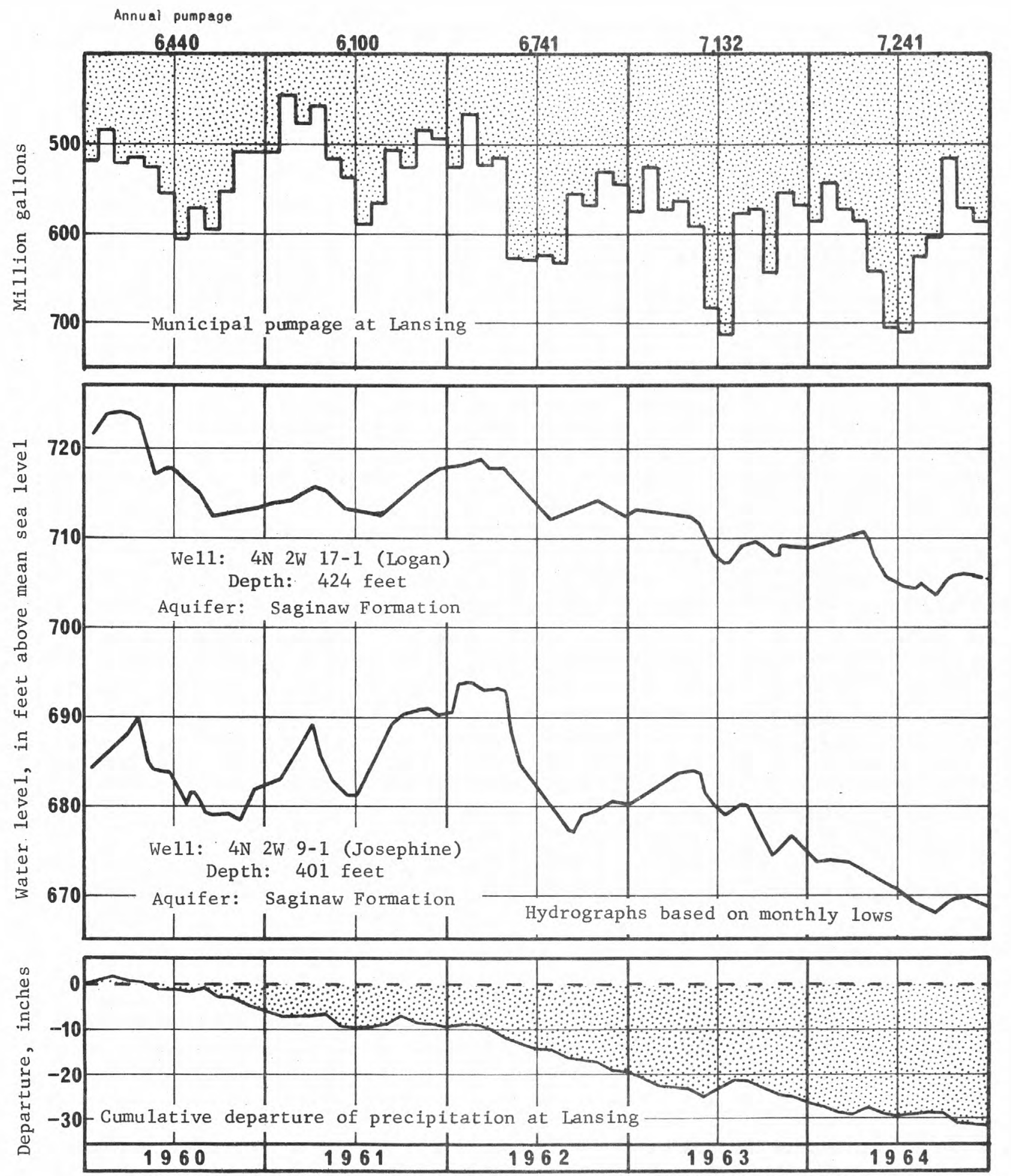

FIGURE 19.--GRAPHS SHOWING WATER LEVELS IN TWO WELLS, PUMPAGE AND PRECIPITATION, IANSING, 1960-64.

The declining trend continued and water levels fell to record lows in 1964. 
Water supp1y -- 115 we11s, 400-425 feet deep, tapping sandstones of the Saginaw Formation. 2 we11s, 50-60 feet deep, in glacial drift are seldom used.

Yield of we1ls in gallons per minute -- 100-700.

Specific capacity of wells in gallons per minute per foot of drawdown -3-10 reported for rock wells.

Pumpage in $1964--7,247$ million gallons. Maximum day -- 40.99 million gallons.

Storage facilities -- Ground storage of $17,000,000$ gallons.

Quality of water -- Treated: Hardness $85 \mathrm{ppm}$ Raw: Hardness 200-600 ppm

Iron $\quad 0.03-4.0 \mathrm{ppm}$

Treatment -- Fluoridation, chlorination, lime softening and iron removal.

Population served -- 107,807 (1960 census).

Per capita use -- 184 gallons per day.

Ground-water conditions -- Water leve1s in observation we $11 \mathrm{~s}$ in the Lansing area continued to decline (figs. $19 \& 20$ ) as the result of continuing deficiencies of precipitation and increasing withdrawals of ground water from the Saginaw Formation. Stages in most of the wells were at or near their lows of record (table 2). While pumpage is contributing to the lowering of water levels, of great concern is the 32 inches of accumulated deficiency of precipitation in the 1960-64 period. This amounts to a years' rainfall lost in the past five years.

A new well field southwest of the City is being developed and will withdraw water from the glacial drift at a proposed rate of about $5 \mathrm{mgd}$. This field should relieve some of the pumping pressure on the Saginaw Formation. An observation we11 (TW 63A) located in the we 11 field shows natural conditions and also effects of some of the test pumping on water levels at the new field (fig. 20).

In 1965 a 4-year study of the water resources of the Tri-County area was begun by the U. S. Geological Survey in cooperation with the Tri-County Planning Commission and the Michigan Department of Conservation. The map (fig. 21) shows location of observation we 11s in this area. 


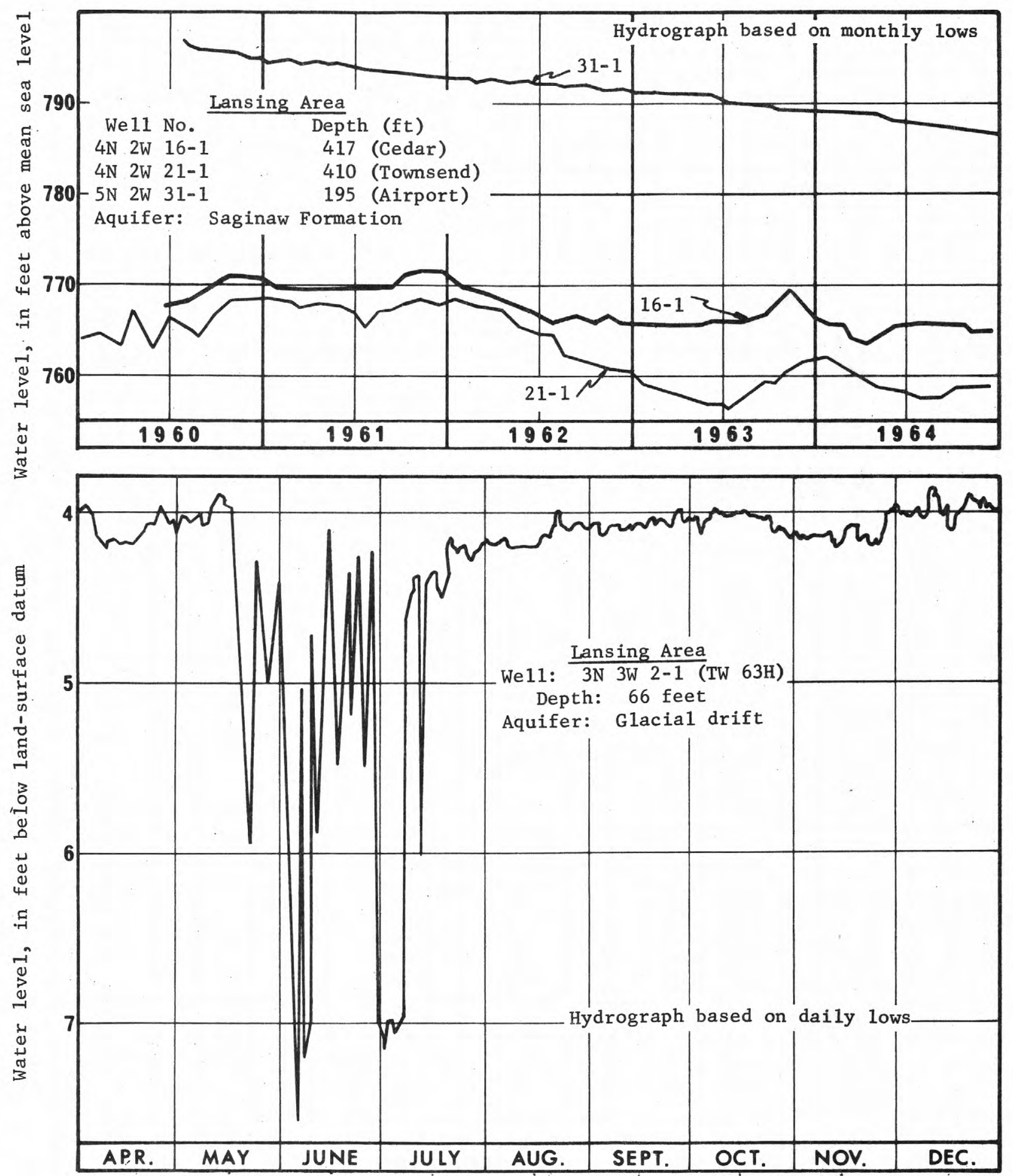

FIGURE 20.--GRAPHS SHOWING WATER LEVELS IN THREE WELLS IN THE LANSING AREA, 1960-64, AND ONE WELL APRIL-DECEMBER, 1964.

The construction of new high-production wells in the glacial drift in the southwest part of the area should alleviate the decline of water levels in the Saginaw Formation. 


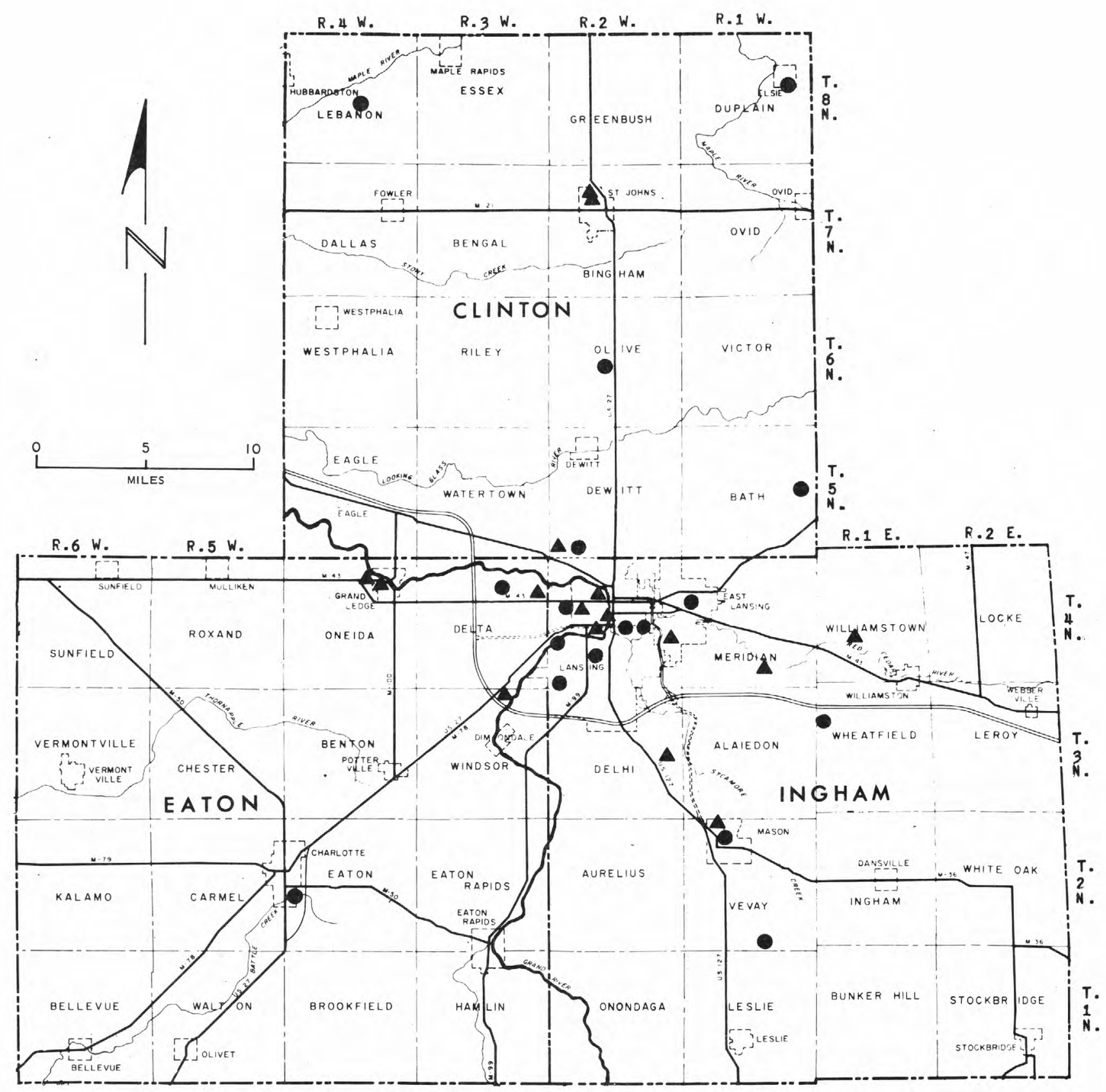

Sites where ground-water level data are obtained

EXPLANATION $\Delta$ Continuous recording gage
- Periodic measurement

FIGURE 21.--LOCATION MAP OF OBSERVATION WELLS IN THE TRI-COUNTY AREA SURROUNDING LANSING.

This area draws water mainly from sandstones of the Saginaw Formation. 
Water supply -- Seven wel1s, 385-400 feet deep, tapping sandstones of the Saginaw Formation.

Yield of we11s in gallons per minute -- 275-900.

Specific capacity of we11s in gallons per minute per foot of drawdown -- 3-11.

Pumpage in 1964 -- 781 million gallons. Maximum day -- 3.96 million gallons.

Storage facilities -- 525,000 gallons elevated.

Quality of water -- Hardness 325-565 ppm Iron $\quad 0.8-7.0 \mathrm{ppm}$ Chloride $\quad 3-34$ ppm

Treatment -- Chlorination, softening and iron removal, Fluoride, Phosphate.

Population served -- 22,871.

Per capita use -- 77.5 gallons per day. 
Water supp1y -- Five we11s, 399-417 feet deep, tapping sandstones of the Saginaw Formation.

Yield of wells in gallons per minute -- 260-500.

Specific capacity of wells in gallons per minute per foot of drawdown -- 2.6-8.

Pumpage in 1964 -- 527 million ga11ons.

Storage facilities -- 200,000 gallons elevated.

Quality of water -- Hardness 290-350 ppm

Iron $\quad 0.4-1.0 \mathrm{ppm}$

Fluoride $0.4 \quad \mathrm{ppm}$

Treatment -- None.

Population served -- 6,100.

*Per capita use -- 236 gallons per day.

* Genera1 Motors Forge and Jet Plant use about 40 million gallons monthly. 
Water supp1y -- Water District No. 1 supplied by water purchased from East Lansing. Water Districts Nos. 2-4 supplied by six we11s, 311-422 feet deep, tapping sandstones of the Saginaw Formation. Lakeview Heights District 非 - Nos. 1 and 2 wells - 311 feet deep, 10-inch diameter; Forest Hills District No. 3 - No. 1 wel1 - 352 feet by 12-inch, No. 2 422 feet by 8-inch; Hillbrooke District No. 4 - No. 1 wel1 - 390 feet by 12 -inch, No. 2 - 390 feet by 8 -inch.

Yield of wells in gallons per minute -- Lakeview Heights - 300; Forest Hills 120 ; Hillbrooke No. 1 - 300, No. 2 - 200.

Specific capacity of wells in gallons per minute per foot of drawdown -- reported $11-30$.

Pumpage in 1964 -- 41.5 million gallons.

Storage facilities -- Elevated storage 30,000 and 50,000 gallons.

Treatment -- None.

Population served -- estimated 2,500.

Per capita use -- 45 gallons per day. 
Water supp1y -- Eight we11s, 300-450 feet deep, tapping sandstones of the Saginaw Formation.

Average yield of we11s in gallons per minute -- 490 .

Average specific capacity of wells in gallons per minute per foot of drawdown -about 5 .

Pumpage in 1964 -- 1,255 million gallons.

Maximum day -- 4.89 million gallons.

Storage facilities -- 1,500,000 gallons below-ground storage.

Quality of water -- Composite -- Hardness 360 ppm

Iron $0.8 \mathrm{ppm}$

Fluoride $0.5 \mathrm{ppm}$

Treatment -- Chlorination, caustic soda to reduce $\mathrm{CO}_{2}$, fluoride, polyphosphate.

Population served -- 30,000.

Per capita use -- 115 gallons per day. 

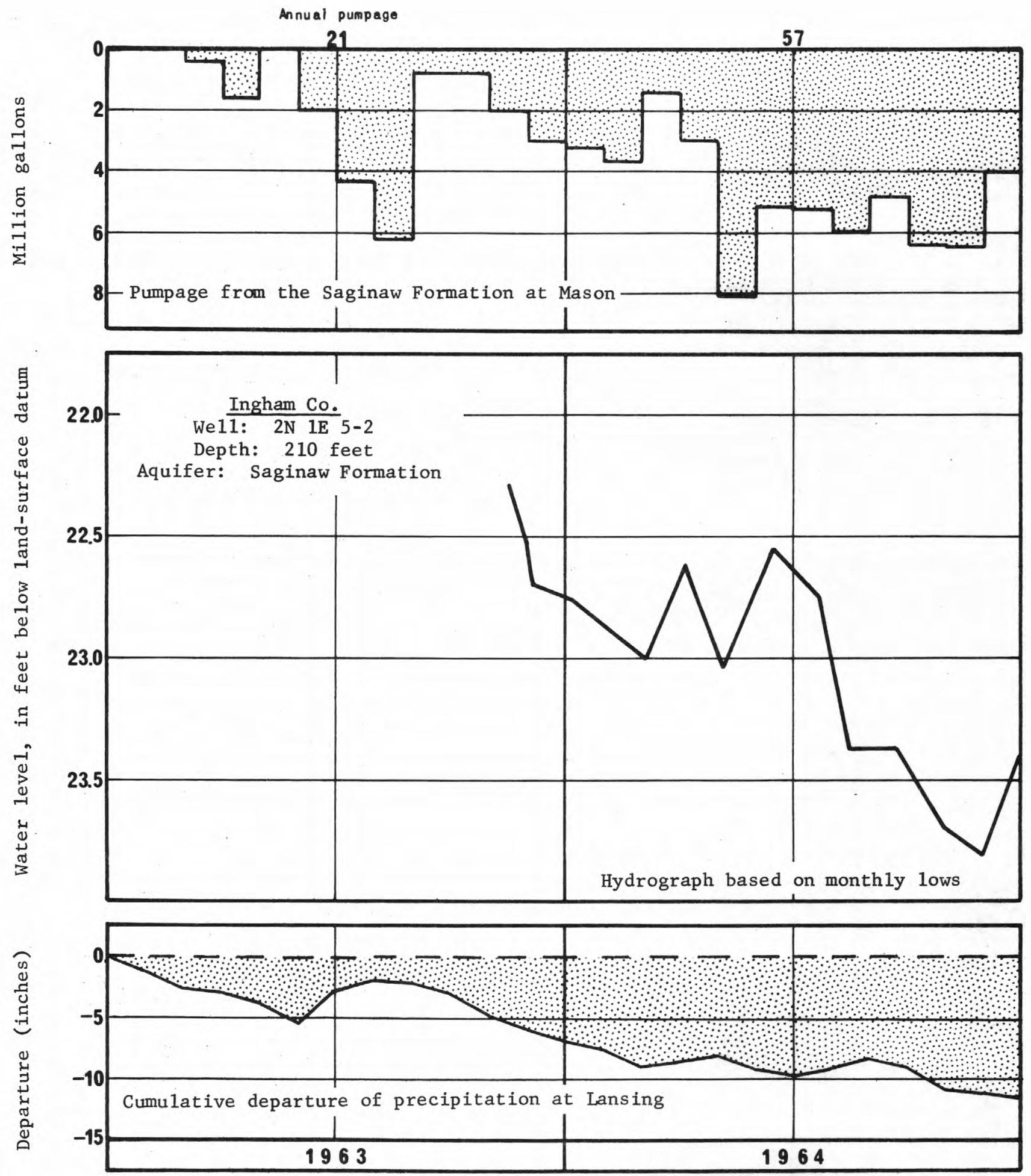

FIGURE 22 .--GRAPHS SHOWING WATER LEVELS, PUMPAGE, AND PRECIPITATION, MASON, 1963-64.

Increased municipal pumpage from the Saginaw Formation and deficient precipitation has resulted in a small decline of water levels. 
Water supply -- Two wells about 50 feet deep finished in glacial drift and one we11, 223 feet deep, tapping sandstones of the Saginaw Formation.

Yield of we11s in gallons per minute -- 300-550.

Specific capacity of wells in gallons per minute per foot of drawdown -非 3 yields 30 from glacial drift.

Pumpage in 1964 -- 169 million gallons.

Storage facilities -- 250,000 elevated and 100,000 standpipe.

Quality of water -- Hardness 310-400 ppm

Iron $0.3 \quad \mathrm{ppm}$

Fluoride 0-0.2 ppm

Chloride 8-44 ppm

Treatment -- None.

Population served -- 4,522.

Per capita use -- 102 gallons per day.

Ground-water conditions -- In 1964 municipal pumpage from the Saginaw Formation more than doubled and as a result of the increased pumpage and continued deficiencies of precipitation, the water levels in the observation we 11 continued to decline slightly (fig. 22). Water levels in wel1 5-1, also finished in the Saginaw Formation (Ingham County, Table 2), fell to record lows of the 17 -year period of observation in 1964. . No observation wells in the glacial drift are currently being measured. Two-thirds of the municipal water pumped is from we 11 s finished in glacia1 drift. 

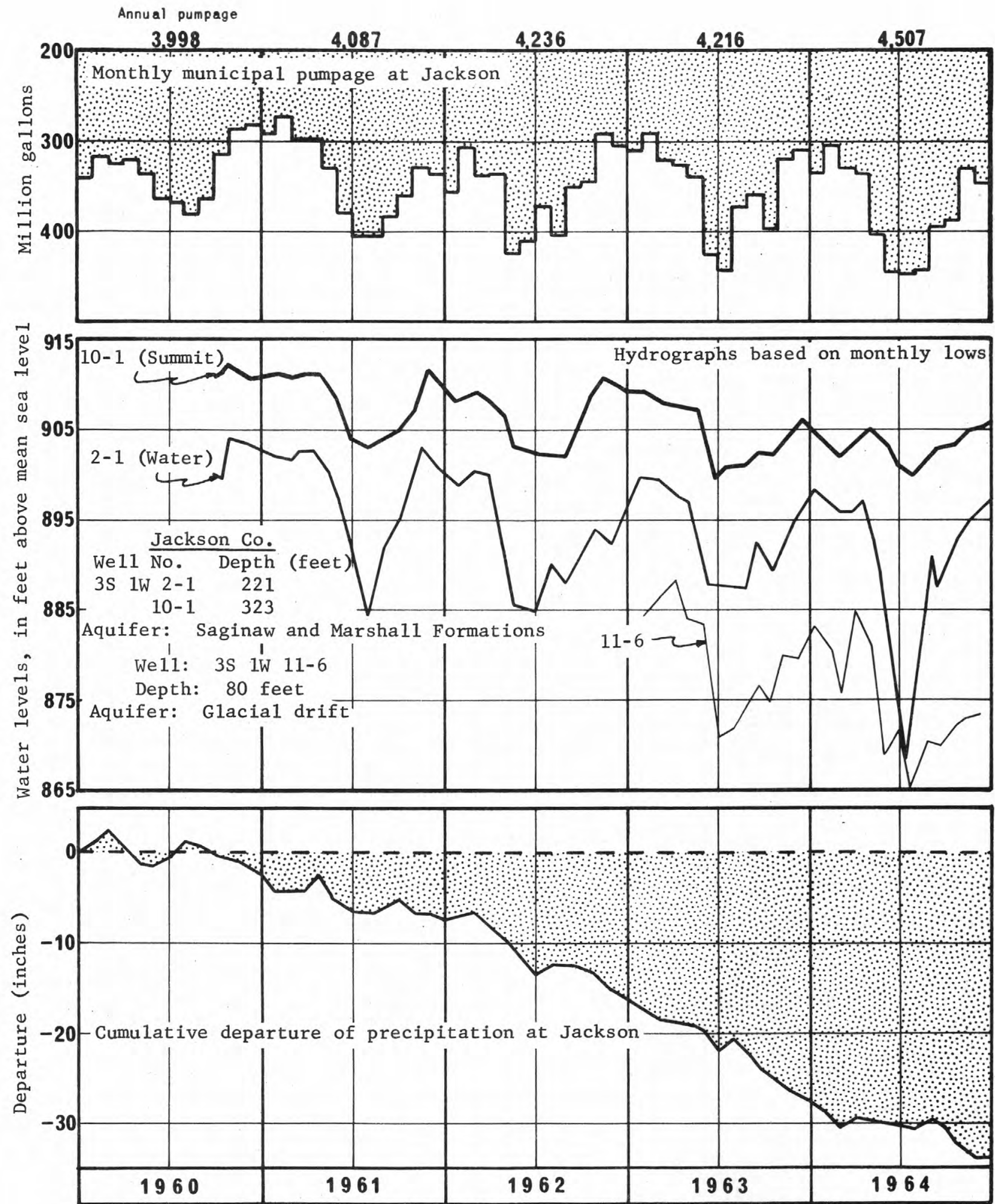

FIGURE 23.--GRAPHS SHOWING WATER LEVELS IN THREE WELLS, PUMPAGE AND PRECIPITATION, JACKSON, 1960-64.

The graph of we11 11-6 finished in the glacial drift indicates hydraulic connection with the water levels in the bedrock we11s. 
Water supply -- 11 wells, 380-400 feet deep, tapping sandstones of the Saginaw, Parma and Marsha11 Formations.

Yield of we11s in gallons per minute -- No. $12-2,000$.

Specific capacity of wells in gallons per minute per foot of drawdown -Reported average 100; specifical1y 非12 we11 - 56.

Pumpage in 1964 -- 4,507 million gallons. Maximum day -- 21.76 million gallons.

Storage facilities -- 3,000,000 ga1lons elevated.

$\begin{array}{cc}\text { Quality of water -- Hardness } & 300-360 \mathrm{ppm} \\ \text { Iron } & 0.3-1.0 \mathrm{ppm}\end{array}$

Chloride 13-88 ppm

Treatment -- Chlorination and fluoridation.

Population served -- 52,220.

Per capita use -- 236 gallons per day.

Ground-water conditions -- Water levels in observation we11s fel1 to record and near-record lows in 1964 as pumpage increased and precipitation deficiencies continued (figs, 23 and 24).

Interconnection between levels in the rock and glacial drift aquifers is evident from the graph of well 11-6 (fig. 23) and the graph of wells in figure 24. In the spring levels in the shallow drift wells benefit from high stages in the Grand River. As pumpage increases and levels in the rock are lowered a hydraulic gradient is created and water from the drift feeds into the rock aquifer through a leaky aquiclude. Leakage from River to adjacent glacial drift aquifer apparently decreases greatly during periods of low streamflow. Wel1 11-6, finished to the top of the rock in glacial drift (fig. $23)$, is located at the Belden Road well field where pumpage from the rock is heaviest. As a result water levels in the rock at this field would be lower than at the Summit and Water Street we11s which are several miles away from the center of pumping influence (see map, fig. 24). The water levels in this drift we1l are lower than the leve1s at the Summit and Water Street we11s, but above the water levels in the Belden field rock we1ls (see observation we11 11-2, Jackson County, table 2). 



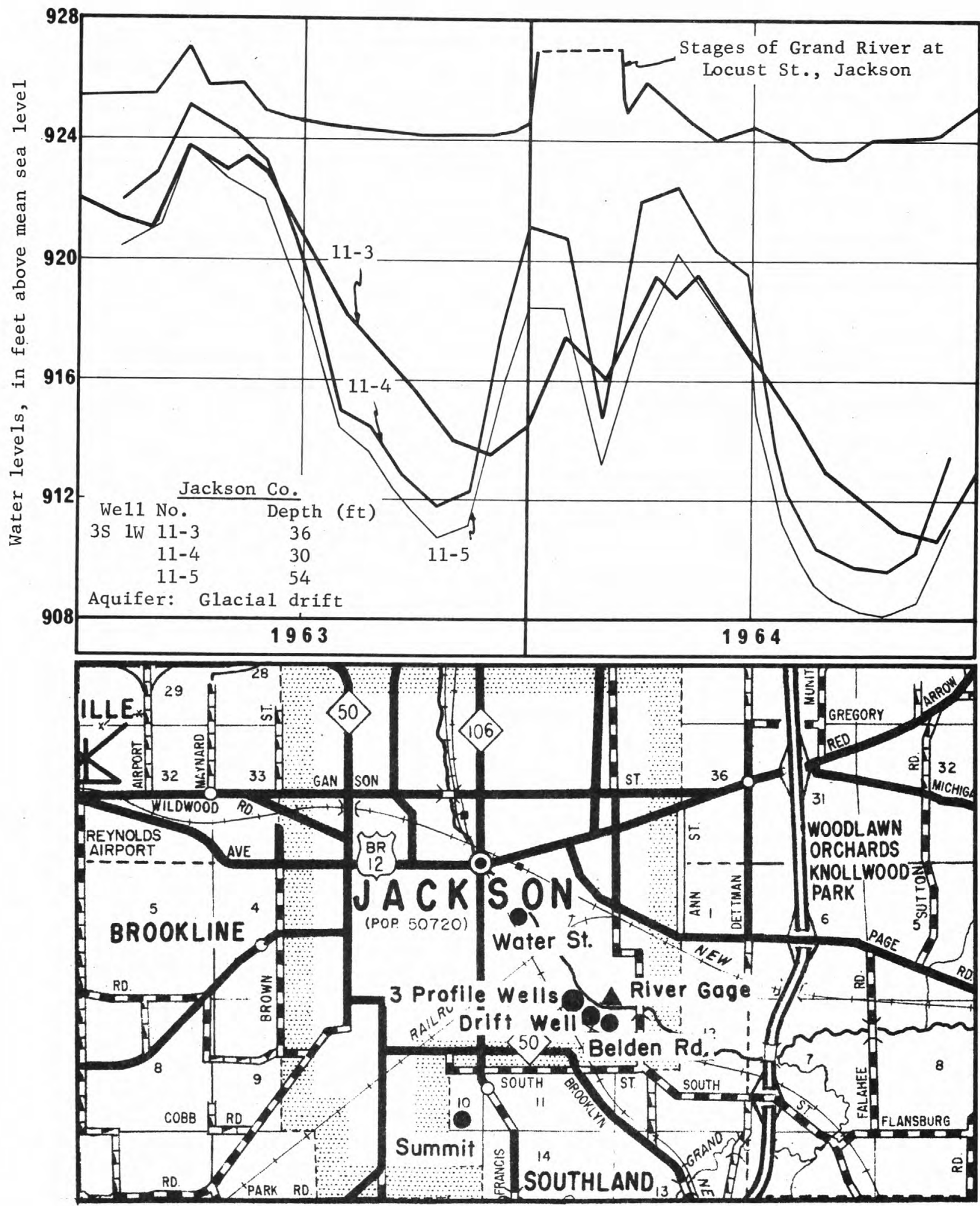

FIGURE 24.--GRAPHS SHOWING WATER LEVELS IN THREE WELLS, AND STAGES OF THE GRAND RIVER, 1963-64, AND LOCATION MAP OF OBSERVATION WELLS, JACKSON.

There seems to be closer correlation of water levels in the drift and water levels in the bedrock than with the Grand River stages. 


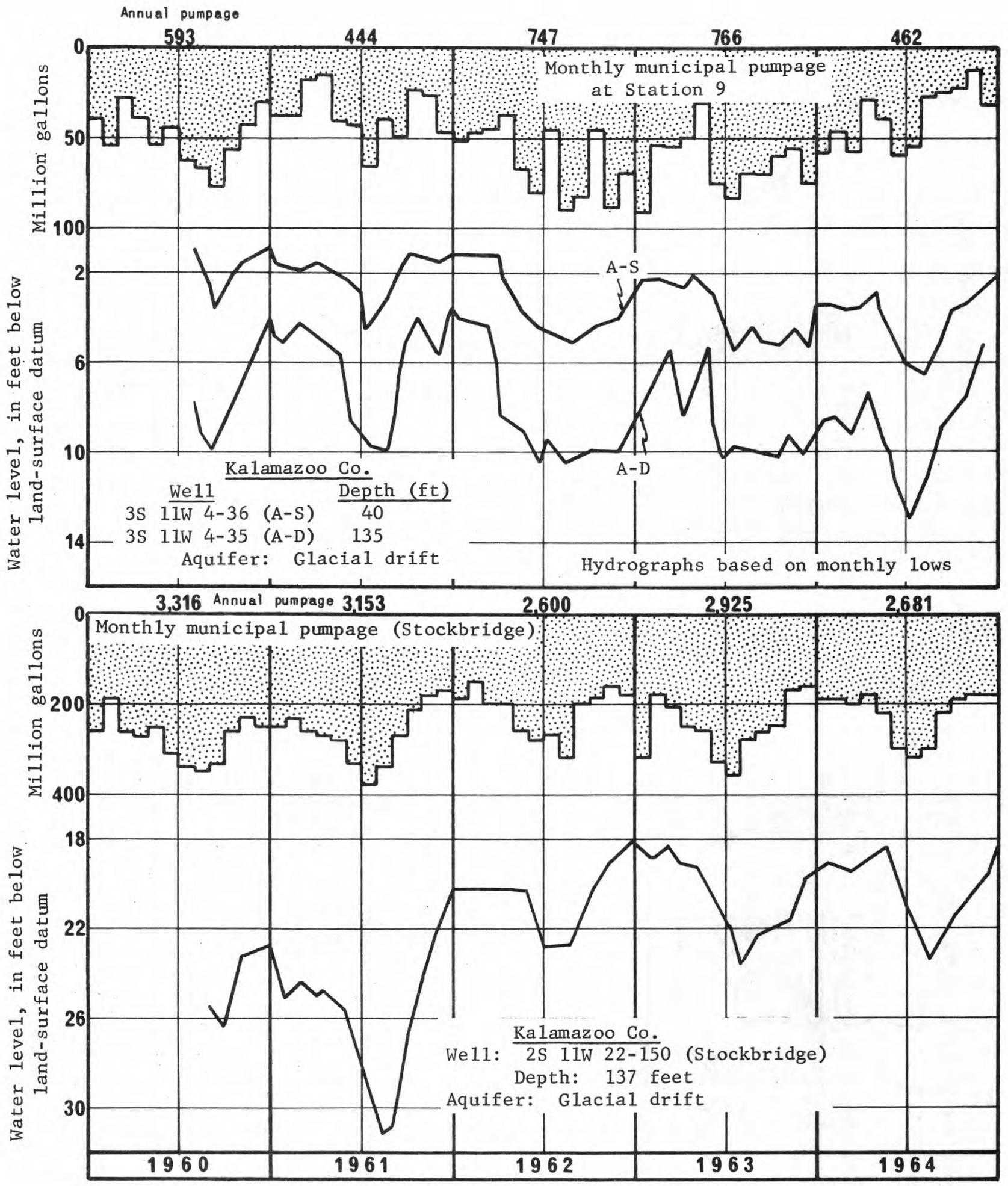

FIGURE 25 ---GRAPHS OF WATER LEVELS, PUMPAGE, AND PRECIPITATION, KALAMAZOO, 1960-64.

Large amounts of water are pumped in the Kalamazoo area with no significant declines in water levels. 
Water supply -- About 79 we11s, 130-254 feet deep, finished in glacial drift.

Yield of wells in gallons per minute -- 200-750.

Specific capacity of wells in gallons per minute per foot of drawdown -- 7-100.

Pumpage in 1964 -- 5,375 million gallons.

Maximum day -- 29.64 million gallons.

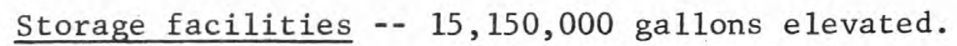

Quality of water -- Hardness 312-350 ppm

Chloride 2-18 ppm

Iron $\quad 0.25-0.75 \mathrm{ppm}$

Treatment -- Chlorination, fluoridation.

Population served -- 100,000 .

Per capita use -- 148 gallons per day.

Ground-water conditions -- The effectiveness of the recharge pond at Station 9 is shown by the graphs of observation wells A-S and A-D (fig. 25). Production wells pump water from the lower aquifer and the water levels in the upper water-table aquifer shows the good interconnection in the similarity of the graphs.

The Stockbridge observation well (fig. 25) reflects withdrawa1s of ground water from the Central pumping area of Kalamazoo. Decreased pumpage has resulted in stable levels the past three years.

Levels in the Kendal1 observation well seem to follow precipitation departures rather than pumpage and the graph resembles that of the Atwater we11 (fig. 26) whose levels are not affected by pumpage. The area is we11 represented by observation we11 coverage (fig. 27). Four new municipal production we 11 s were put into operation in 1964, one at Kendall field and three at Station 22.

A 3-year study of the water resources of Kalamazoo County is currently being conducted by the U. S. Geological Survey with completion date in December, 1967. 

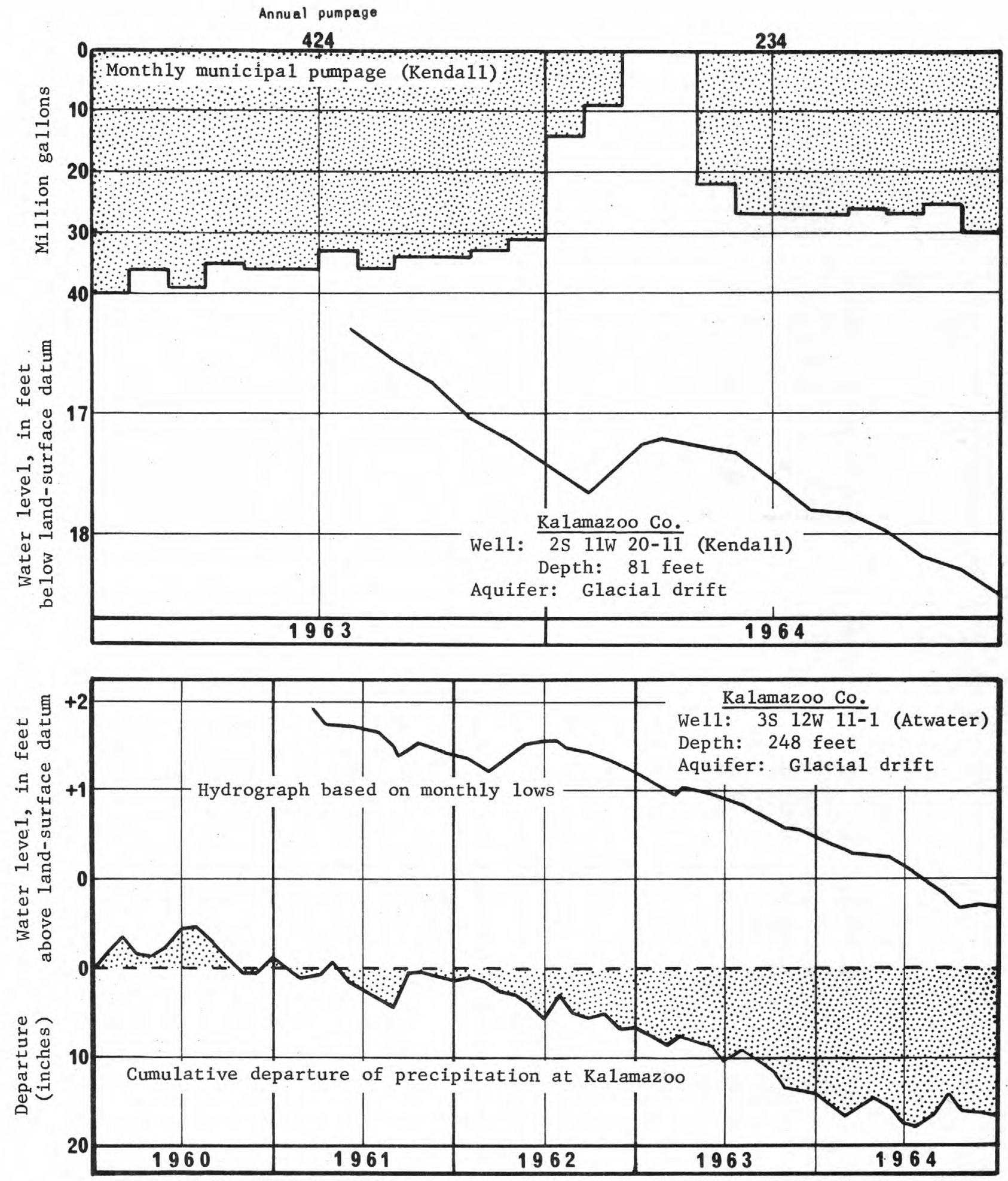

FIGURE 26.--GRAPHS OF WATER LEVELS IN TWO WELLS, PUMPAGE AND PRECIPITATION, KALAMAZOO, 1960-64.

The Atwater we11 is not near pumping wells and shows mostly the effects of climate. 
i. 11 W.

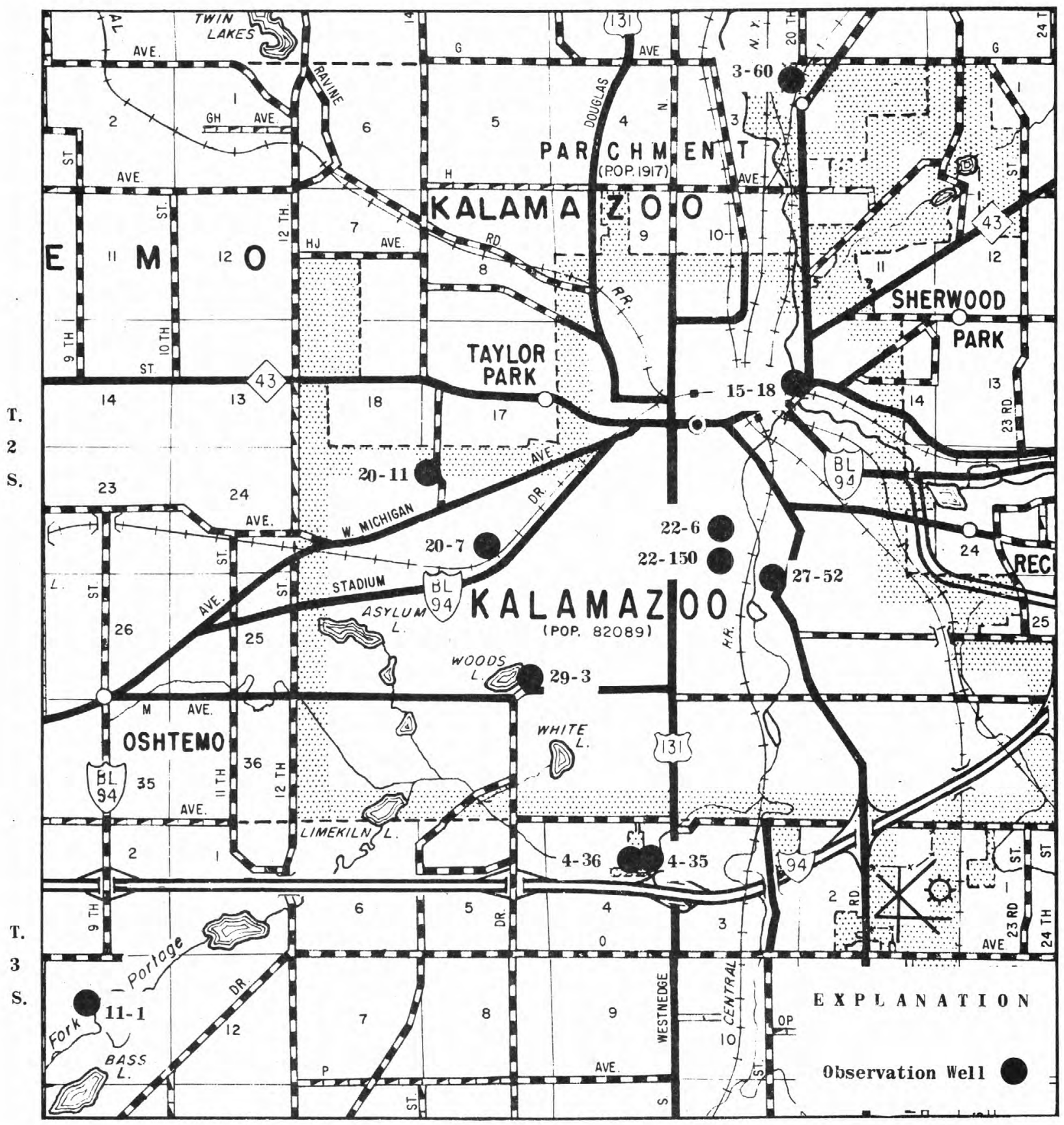

FIGURE 27.--MAP OF KALAMAZOO AREA SHOWING LOCATION OF OBSERVATION WELLS.

11 observation wells are located in the area, of which 5 are equipped with continuous recording gages. 

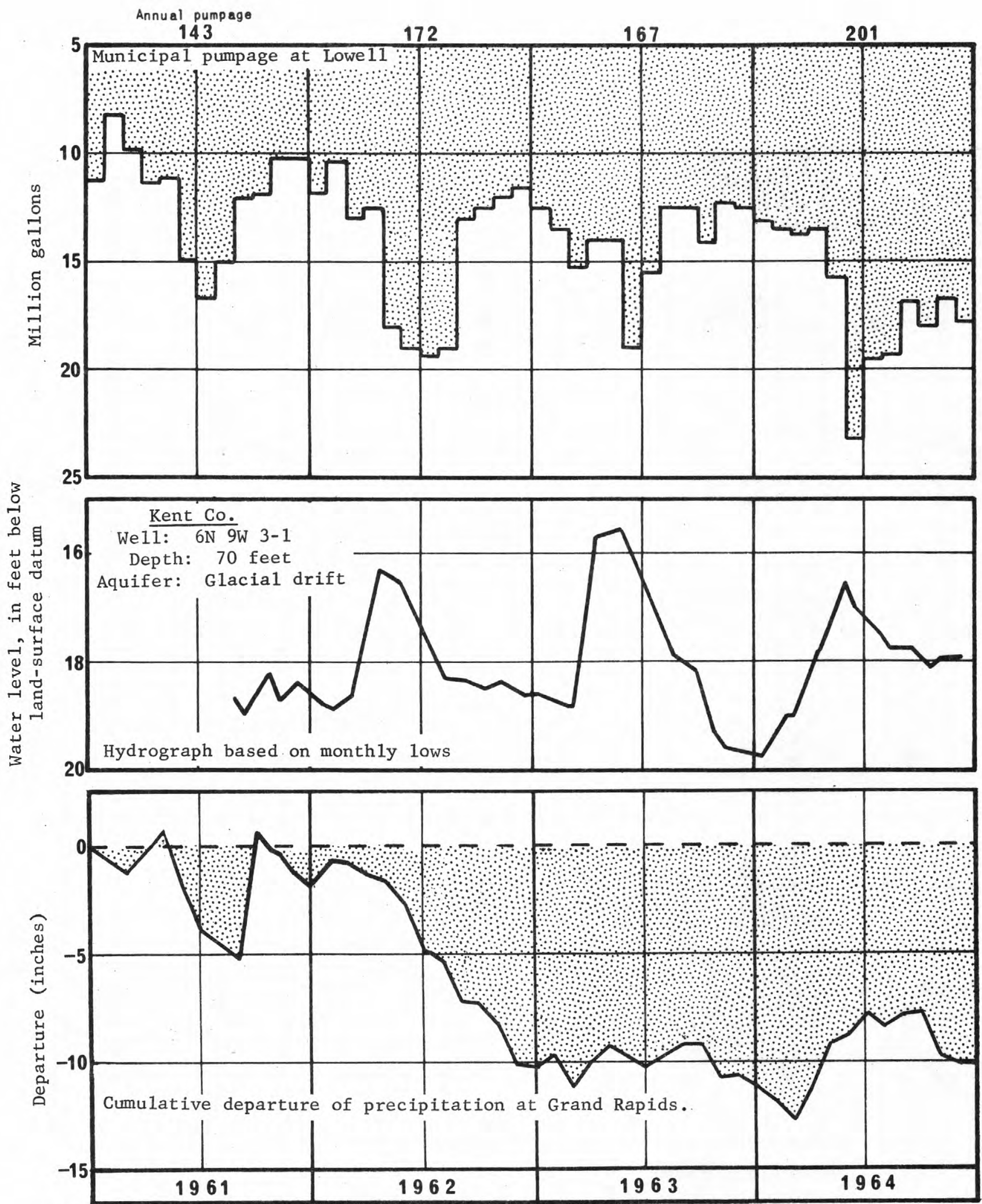

FIGURE 28.--GRAPHS SHOWING WATER LEVELS, PUMPAGE, AND PRECIPITATION, LOWELL, 1961-64.

No decline of water levels is occurring despite overall deficiency of precipitation and increasing pumpage. 
Water supply -- In 1964 two wells, 47 and 71 feet deep, finished in glacial drift and one we11, 107 feet deep, tapping Ionia sandstones of Pennsylvania age.

Yield of wells in gallons per minute -- 350 (Rock); 120-800 (Drift).

Specific capacity of wells in gallons per minute per foot of drawdown -4.5 and 80 (Drift) and 13.2 (Rock).

Pumpage in 1964 -- 201 million gallons.

Storage facilities -- 500,000 gallons elevated.

Quality of water -- Hardness 210-352 ppm Iron $\quad 0.3-0.4 \mathrm{ppm}$

Treatment -- Chlorination and fluoridation.

Population served -- 2,545.

Per capita use -- 215 gallons per day.

Ground-water conditions -- The observation well (fig. 28) is finished in glacial drift and water levels reflect withdrawals from the drift aquifer. Although there was an overall increase of pumpage, precipitation was above normal in 1964 and water levels rose about 2 feet in the observation we 11 above the low at the beginning of the year. The 1964 pumpage was about $41 \%$ more than was pumped in 1961 . 

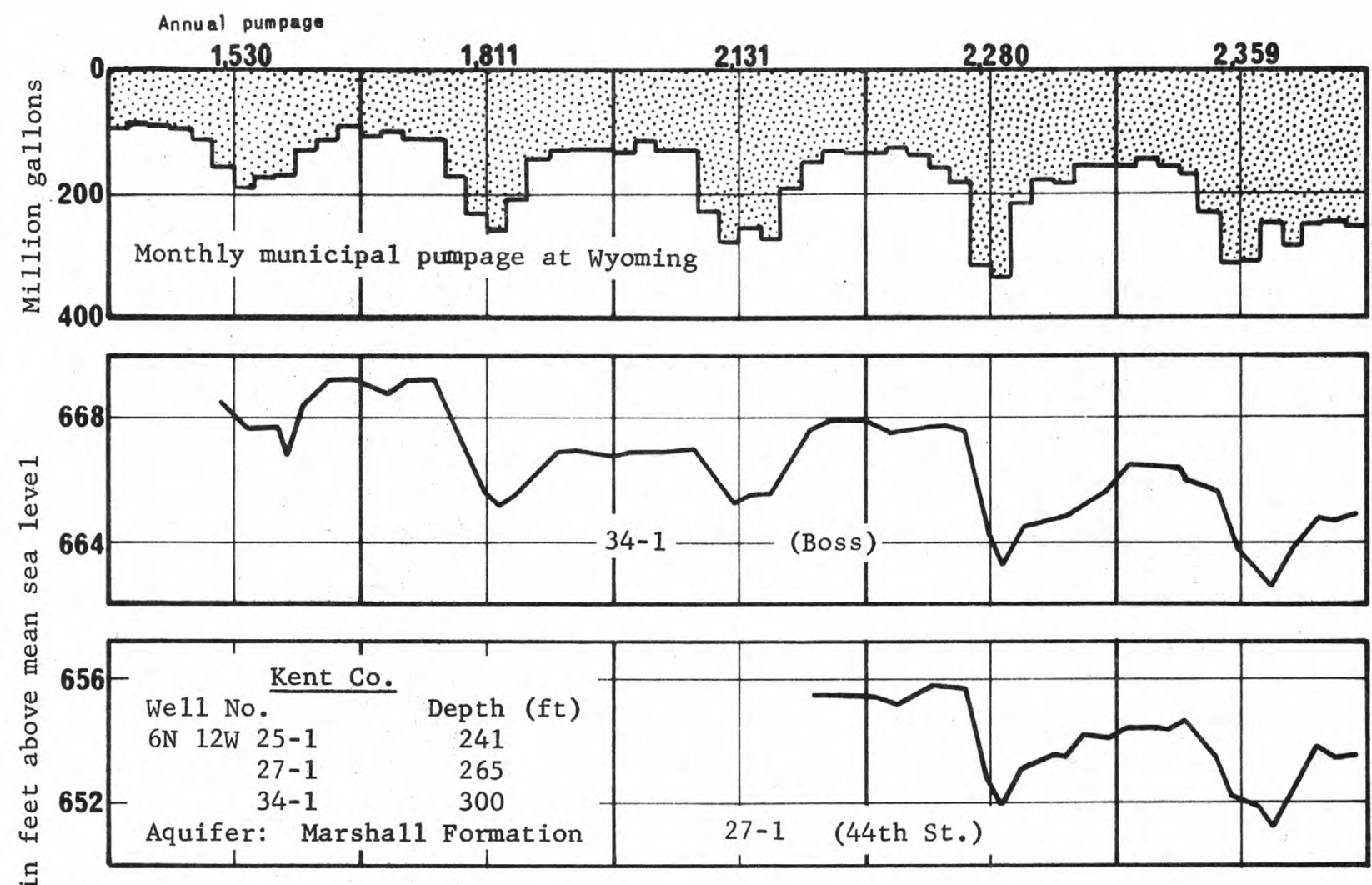

.
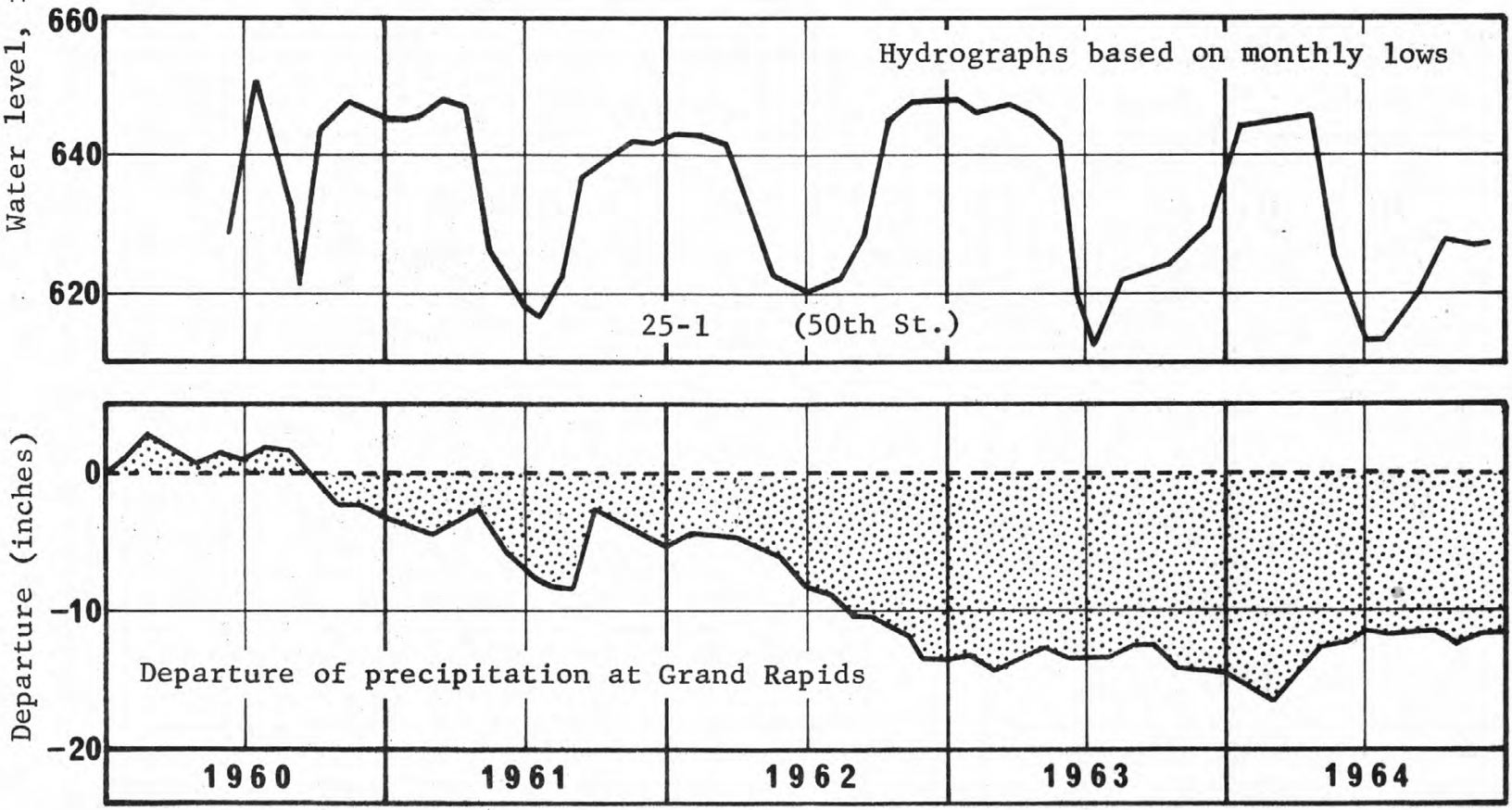

FIGURE 29 .--GRAPHS SHOWING WATER LEVELS IN THREE WELLS, PUMPAGE, AND PRECIPITATION, WYOMING, 1960-64.

Despite a large increase in pumpage and deficient precipitation only a slight declining trend has occurred. 
Water supply -- About 20 we11s, 50-298 feet deep, located in seven we11 fields, are finished in glacial drift or in sandstones of the Marshall

Formation.

Yield of we11s in gallons per minute -- 250-1, 100 .

Specific capacity of welis in gallons per minute per foot of drawdown -- 8-10 in sandstone; 14-140 in drift we11s.

Pumpage in $1964-2,357$ million gallons. Maximum day -- 16.44 million gallons.

Storage facilities -- 5,000,000 gallons ground storage and 300,000 ga11ons elevated storage.

Quality of water -- Hardness 285-361 ppm Chlorides 12-610 ppm Iron $\quad 0-3.5 \mathrm{ppm}$

Treatment -- Chlorination, fluoridation and calgon.

Population served -- about 35,000.

Per capita use -- 184 gallons per day.

Ground-water conditions -- The declining trend in water levels continued although precipitation was above average in 1964 (figs. 29 and 30). Of the six observation wells five fell to new lows of record (table 2, Kent County).

Observation we11s 4-3, 4-7 and 11-3 are 2-3 miles from pumping we11 fields (see map, fig. 31). The similarity of the hydrographs shows the good hydraulic connection between the glacial drift and the rock aquifer (fig. 30). 

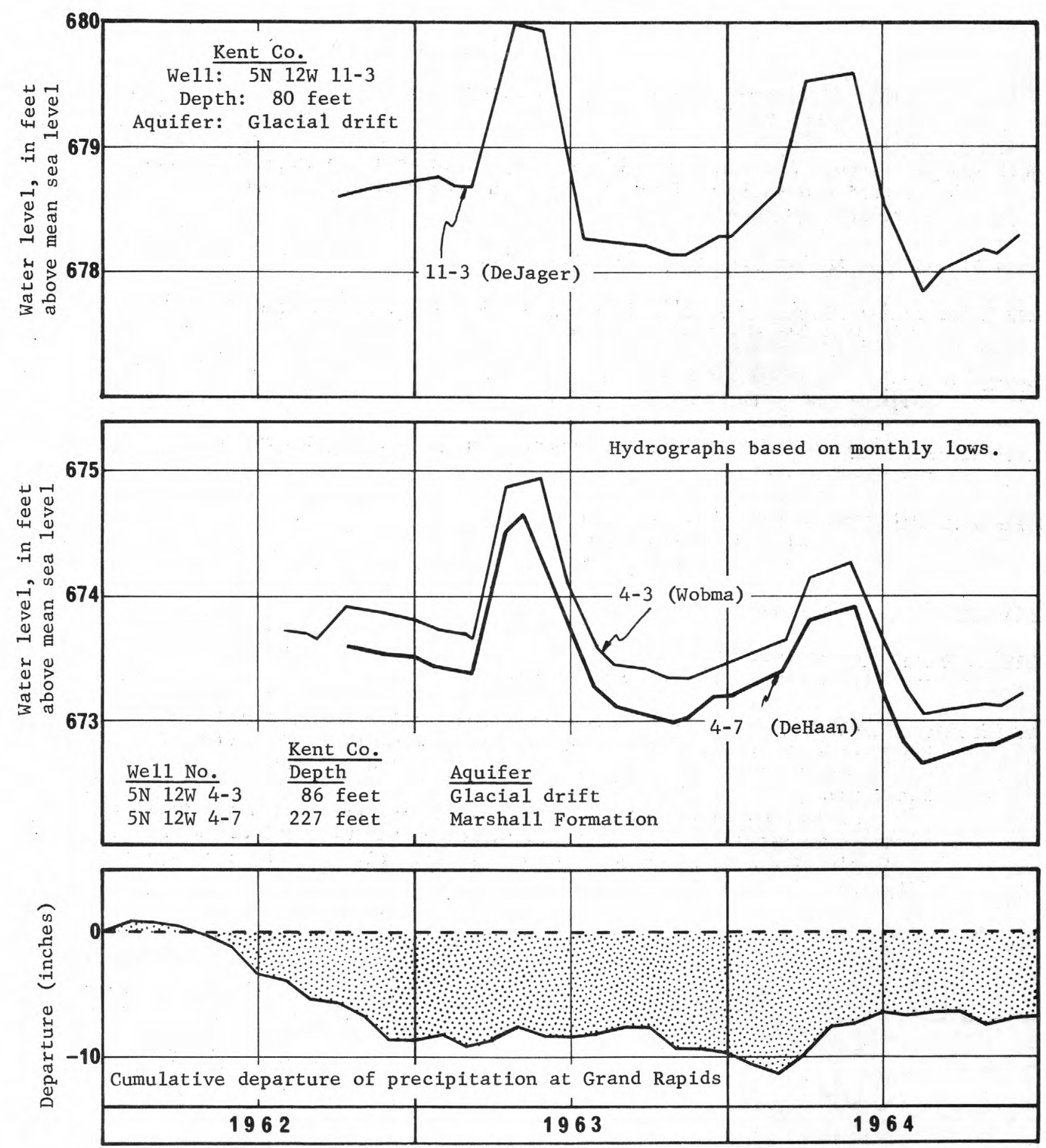

FIGURE 30.--GRAPHS SHOWING WATER LEVELS IN THREE WELLS, AND PRECIPITATION, WYOMING, 1962-64.

The water level in these wells shows good hydraulic connection between the glacial drift and Marshall Formation. 


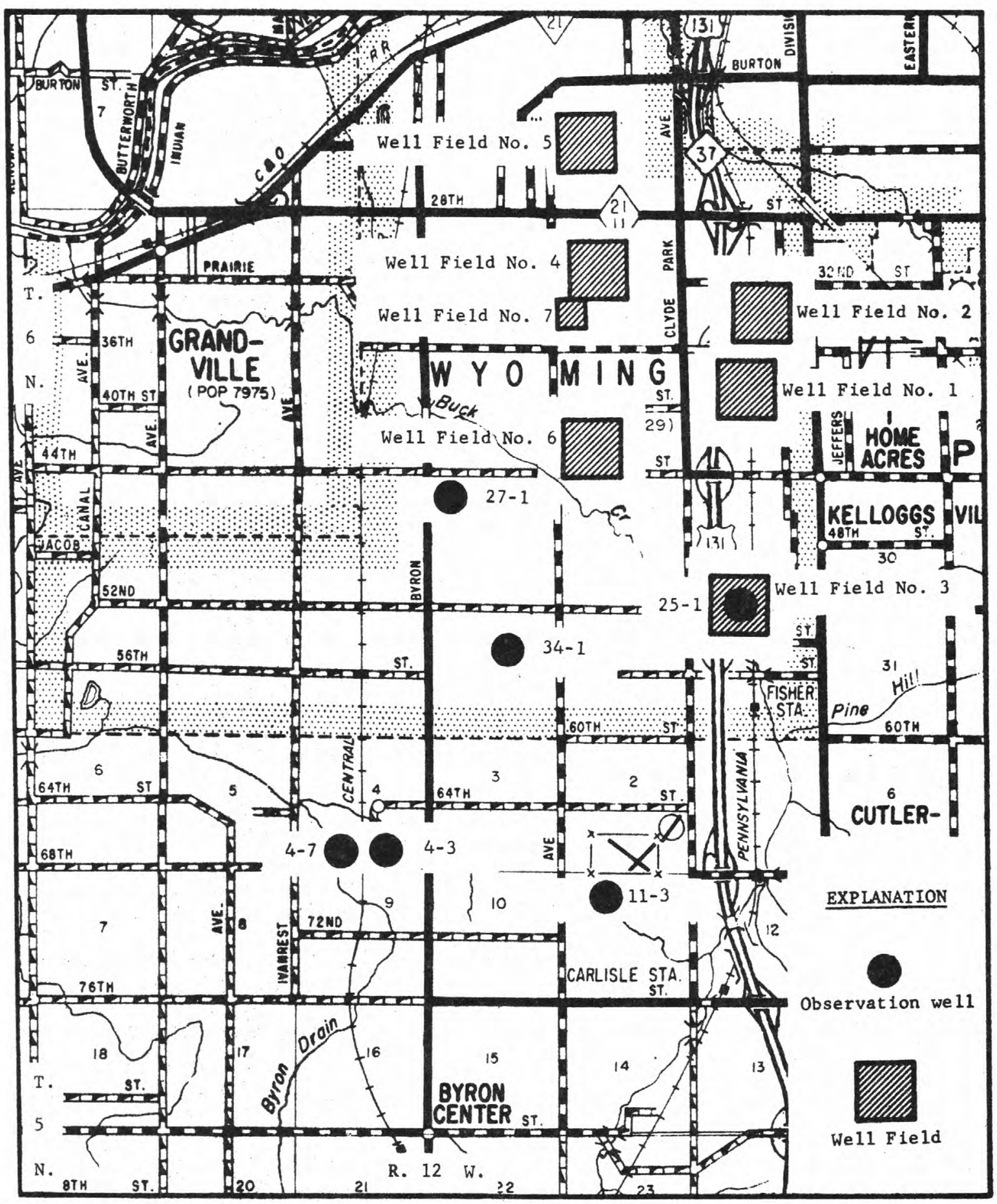

FIGURE 31,--LOCATION MAP OF WELLS AT WYOMING. 


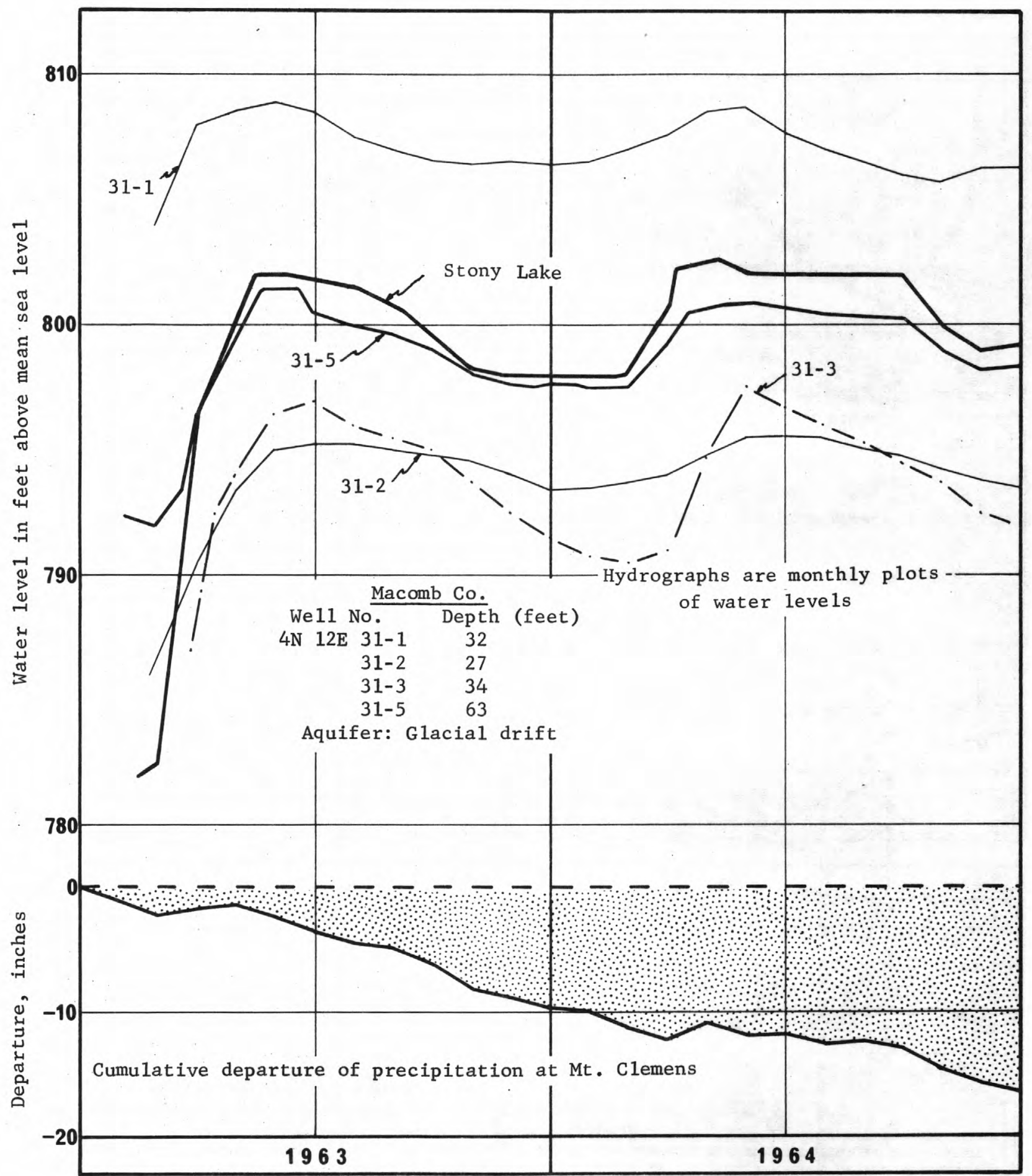

FIGURE 32 ---GRAPHS SHOWING WATER LEVELS IN FOUR WELLS AND STONY LAKE, NEAR ROCHESTER, 1963-64.

The lake level is higher than the level in three of the observation wells resulting in some loss to the ground-water table. 


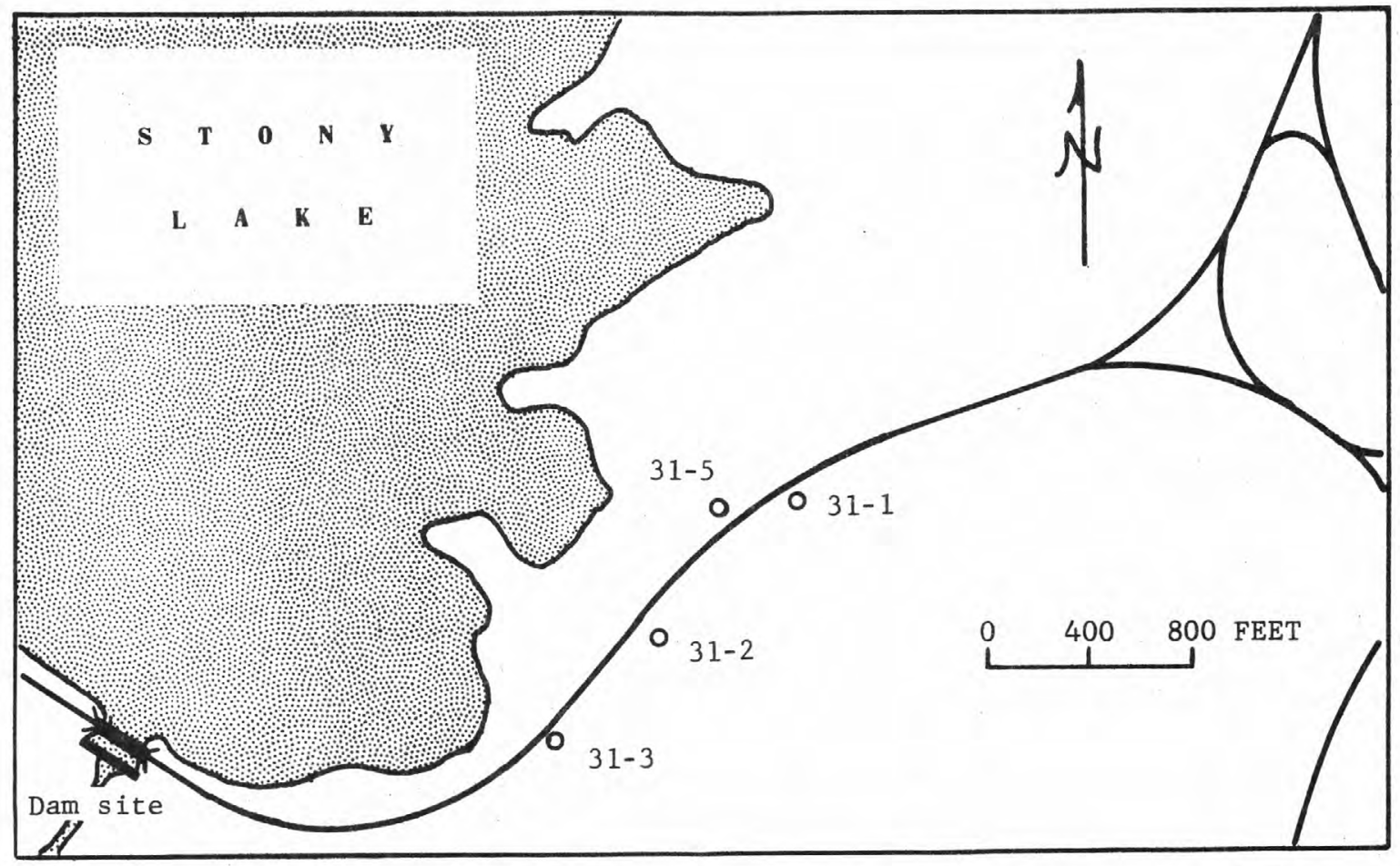

FIGURE 33.--LOCATION OF OBSERVATION WELLS AT STONY CREEK PARK, NEAR ROCHESTER.

MACOMB COUNTY -- Observation we1ls are maintained at Stony Lake Park, of the Huron-Clinton Metropolitan Authority, to observe the effects of the damming of a creek to create a lake for recreationa 1 purposes. The level of the lake (fig. 32) is higher than the surrounding groundwater elevations except for we11 31-1 which is deeper and further from the dam site. Some loss of surface water to the water table thus occurs. However, it is possible that ground-water levels are at present low from the accumulated deficiencies of precipitation and that in normal years those ground-water levels may then be higher than the lake and thus reverse the present trend. The location of the wells in relation to the lake are shown above (fig. 33). 


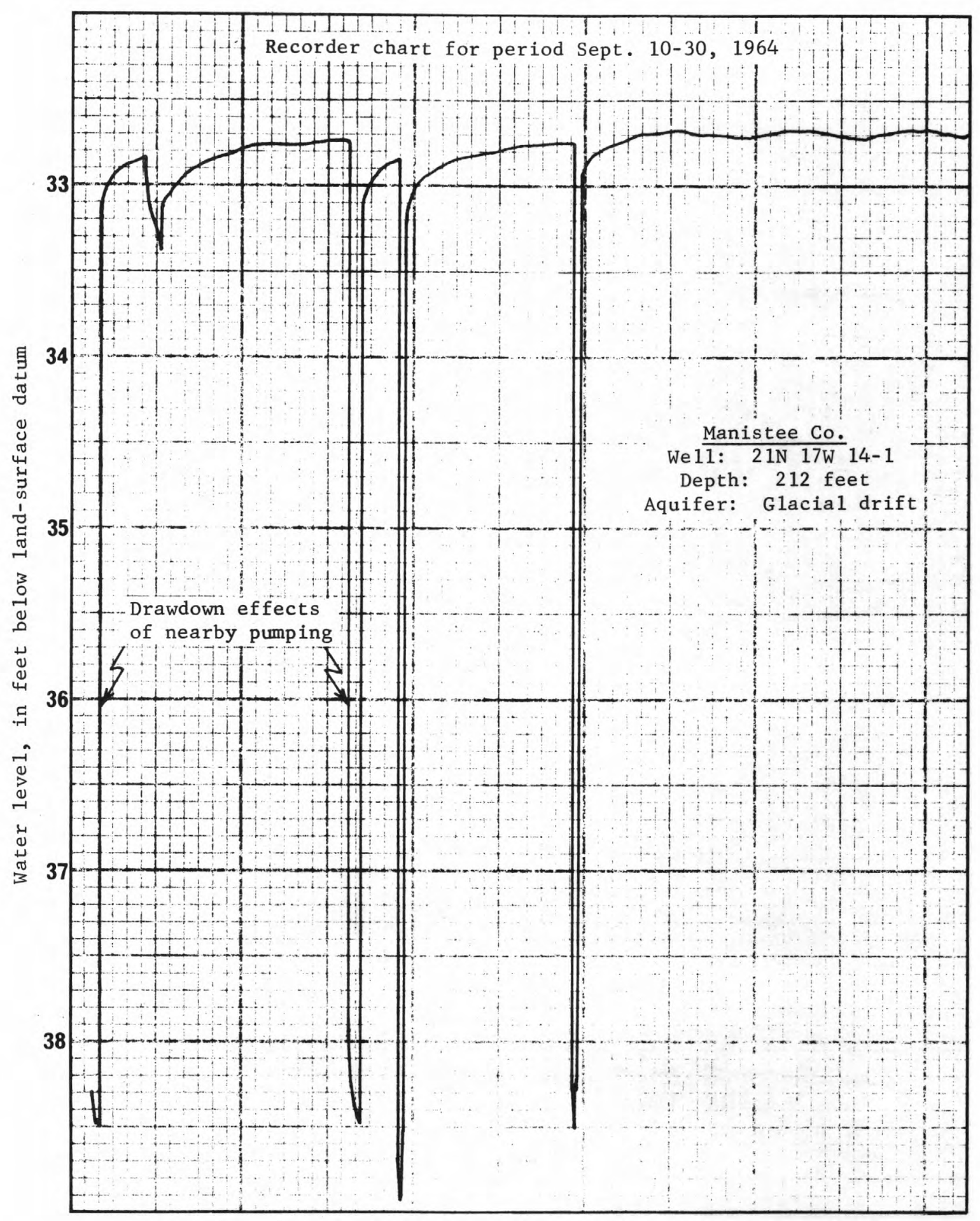

FIGURE $34 .--$ RECORDER CHART SHOWING CHANGES IN WATER LEVELS OWING TO OCCASIONAL PUMPING OF A WELL FIELD AT MANISTEE.

This new well field was pumped occasionally for short periods of time in the fall of 1964. 
Water supply -- Five we1ls, 97 to 205 feet deep, finished in glacial drift.

Yield of wells in gallons per minute -- 非 - 350; 非 - 500; 非 - 350; 非 - 2,000; 非 $-2,000$.

Specific capacity of wells in gallons per minute per foot of drawdown -- 25-39.

Pumpage in 1964 -- 463 million gallons.

Maximun day -- 2.98 million gallons.

Storage facilities -- 500,000 gallons elevated.

Quality of water -- Hardness 169-207 ppm

Iron $\quad 0.1-0.4 \mathrm{ppm}$

Chloride 2-75 ppm

Treatment -- None.

Population served -- 8,324 .

Per capita use -- 152 gallons per day.

Ground-water conditions -- Water levels in the observation we11 located at the new well field remained relatively steady during the year. Although several million gallons were pumped in the latter part of 1964 from new we 1ls nearby, static levels declined only about 0.3 of a foot for the year. The effects of pumping of a nearby production we11, 10 feet away, on the water levels in the observation we11 is shown in figure 34. 


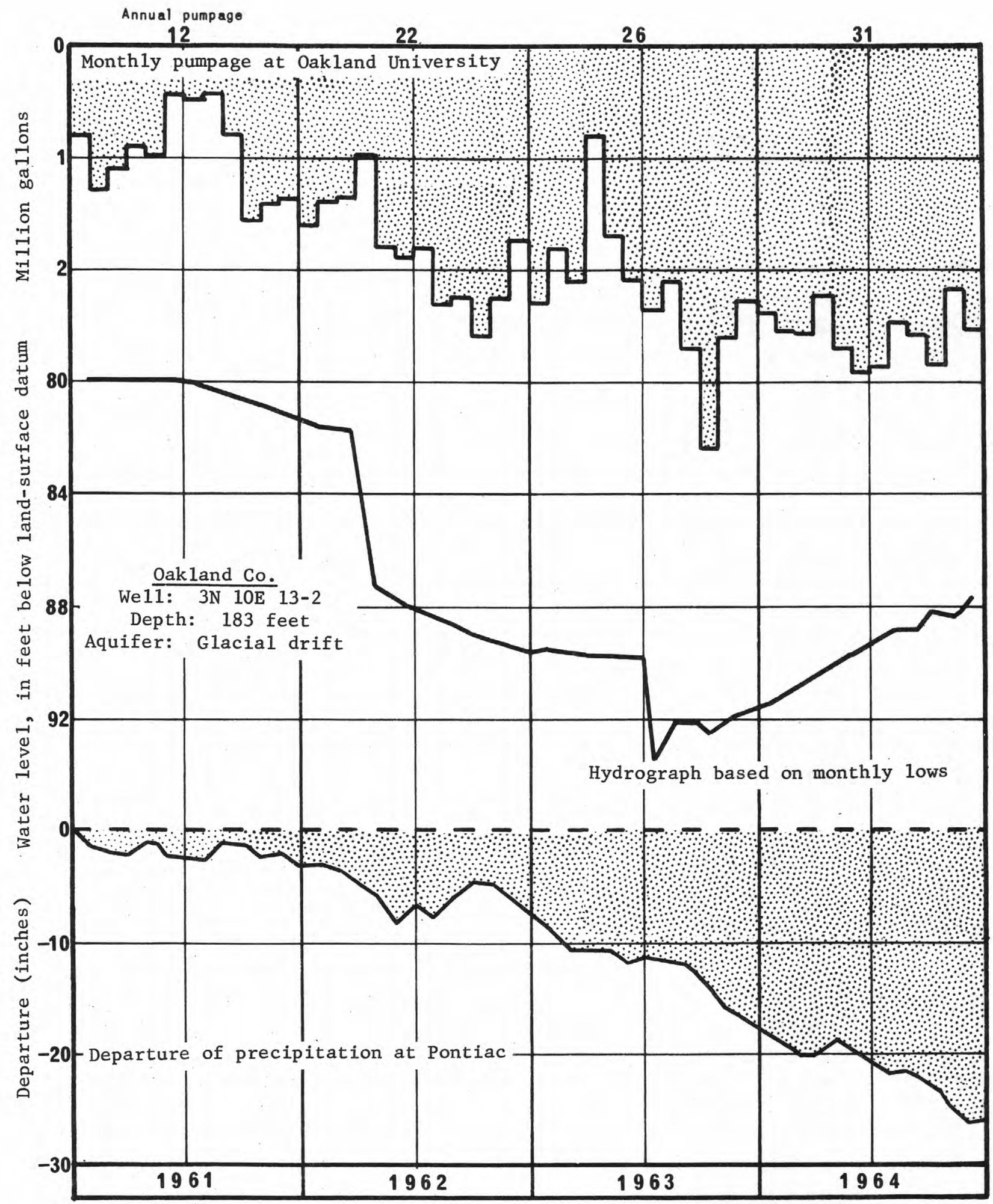

FIGURE 35.--GRAPHS SHOWING WATER LEVELS, PUMPAGE, PRECIPITATION, OAKLAND UNIVERSITY NEAR PONTIAC, 1961-64.

A rise in water levels occurred from mid-1963 because of the discontinuance of municipal pumpage of ground-water in Pontiac. 
Water supply -- Two wells, 149 and 184 feet deep, finished in glacial drift.

Yield of wells in gallons per minute -- 600 from 184-foot deep wel1.

Specific capacity of wells in gallons per minute per foot of drawdown -- 32 from a 6" Test we11.

Pumpage in 1964 -- 30.7 million gallons.

Maximum day -- .124 million ga11ons 。

Storage facilities -- 12,900 gallons hydraulic pneumatic storage.

Quality of water -- Hardness 340-555 ppm

Iron 2.3-0.1 $\mathrm{ppm}$

Fluoride $0.0-0.3 \mathrm{ppm}$

Treatment -- Chlorine, polyphosphate added.

Population served -- estimated 2,000.

Per capita use - 42 gallons per day.

Ground-water conditions -- Water levels in the observation we11 (fig. 35) rose nearly 6 feet since August, 1963 principally as the result of the discontinuance of pumping by the City of Pontiac a few miles west. The rise occurred despite increased University pumpage and the continued deficiency of precipitation. 


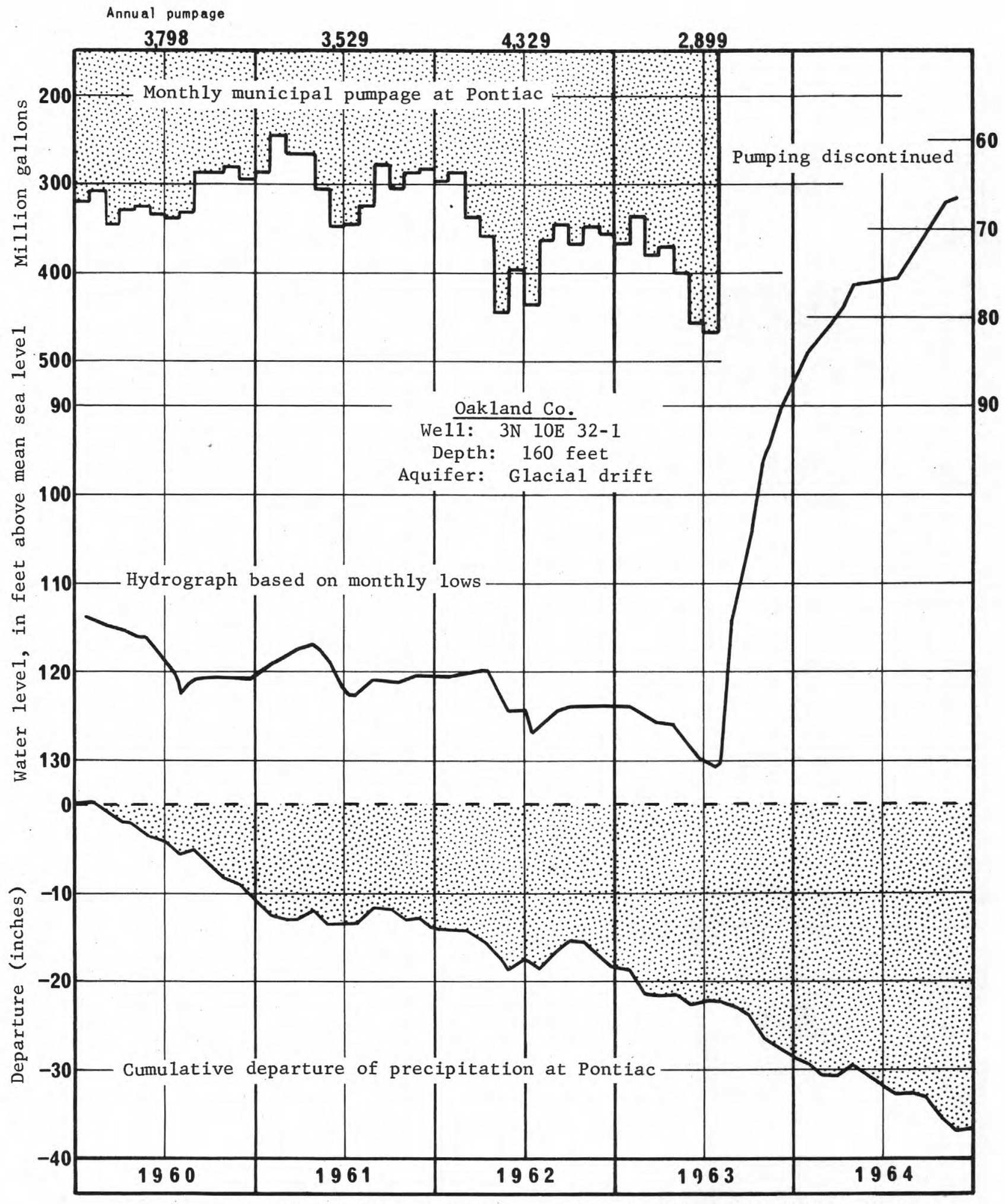

FIGURE 36.--GRAPHS SHOWING WATER LEVELS, PUMPAGE, AND PRECIPITATION, PONTIAC, 1960-64.

Water levels have risen 65 feet since pumpage was discontinued. 
Water supply -- From Detroit municipal system. Ground-water system abandoned in August, 1963.

Ground-water conditions -- Levels continued to recover in the two observation wells at Pontiac (Table 2 - Oakland County) in response to the discontinuance of pumping of ground water by the City. A rise of 65 feet occurred in well 32-1 (fig. 36) despite the continued deficiency of precipitation at Pontiac. In the 5-year period a deficiency of about 37 inches has occurred. More than a year's normal rainfal1 of 31 inches has been lost. 


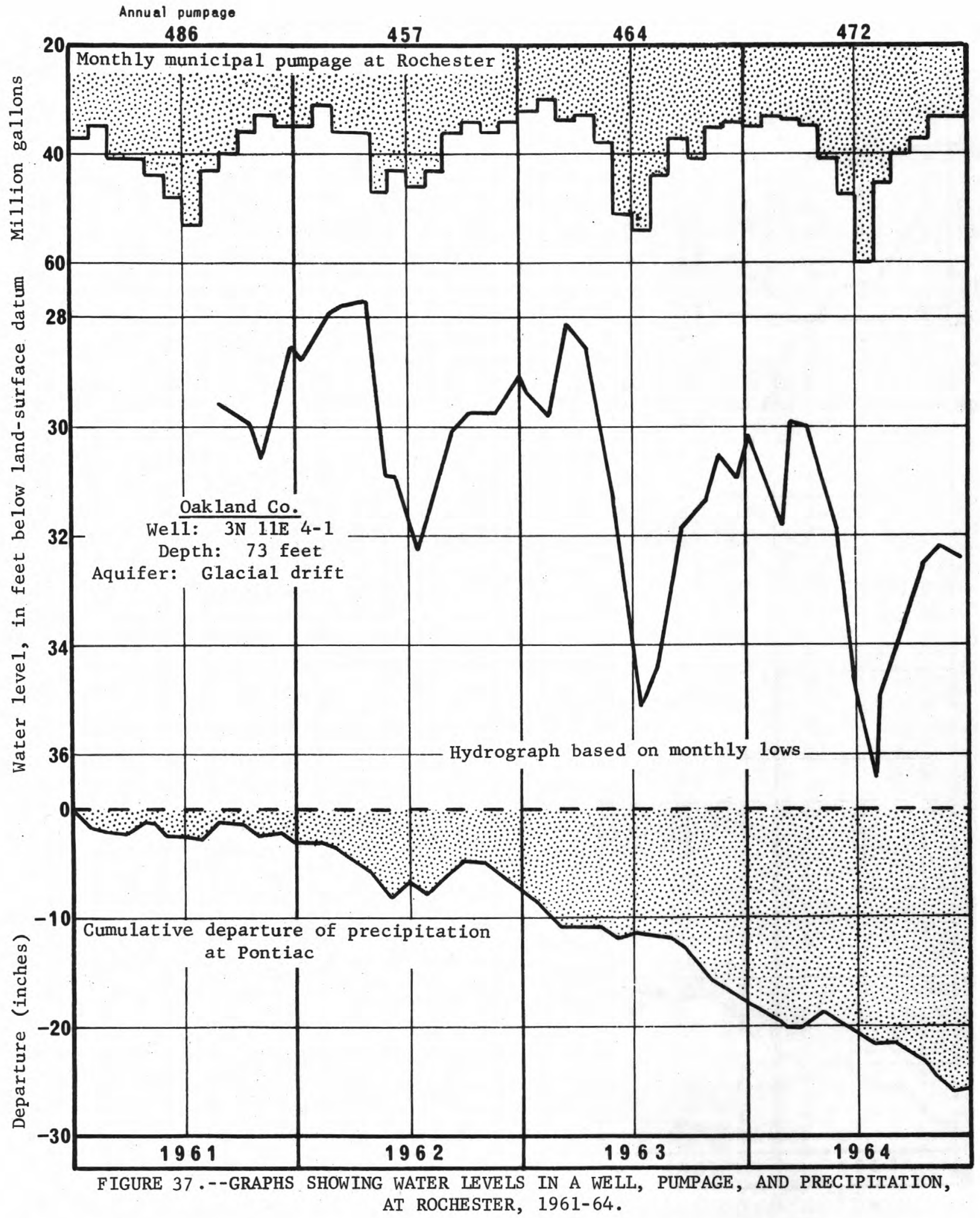

Most of the decline in water levels is apparently the result of deficient precipitation as pumpage has not increased significantly. 
OAKLAND COUNTY - VILLAGE OF ROCHESTER

Water supply -- Four we11s, 65-147 feet deep, finished in glacial drift.

Yield of wells in gallons per minute -- No. $1-600 ;$ no. 2 - 800; nos. 3 \& 4 1,000 .

Specific capacity of wells in gallons per minute per foot of drawdown -- No. 1 22 ; no. 2 - 27 ; no. 3 - 110 ; no. 4 - 56 .

Pumpage in 1964 - 472 million gallons. Maximum day -- 2.72 million gallons.

Storage facilities -- 750,000 gallons elevated.

Quality of water -- Hardness 305-330 ppm

Iron $\quad 1.2-1.4 \mathrm{ppm}$

Fluoride $0.3 \mathrm{ppm}$

Treatment -- None.

Population served -- estimated 7,000.

Per capita use -- 145 gallons per day.

Ground-water conditions -- Levels fell to new lows of record for the third consecutive year as precipitation continued to be deficient (fig. 37). No large increase in pumpage has occurred. The effects of the discontinuance of pumping by Pontiac to the west is not apparent in this well field. 

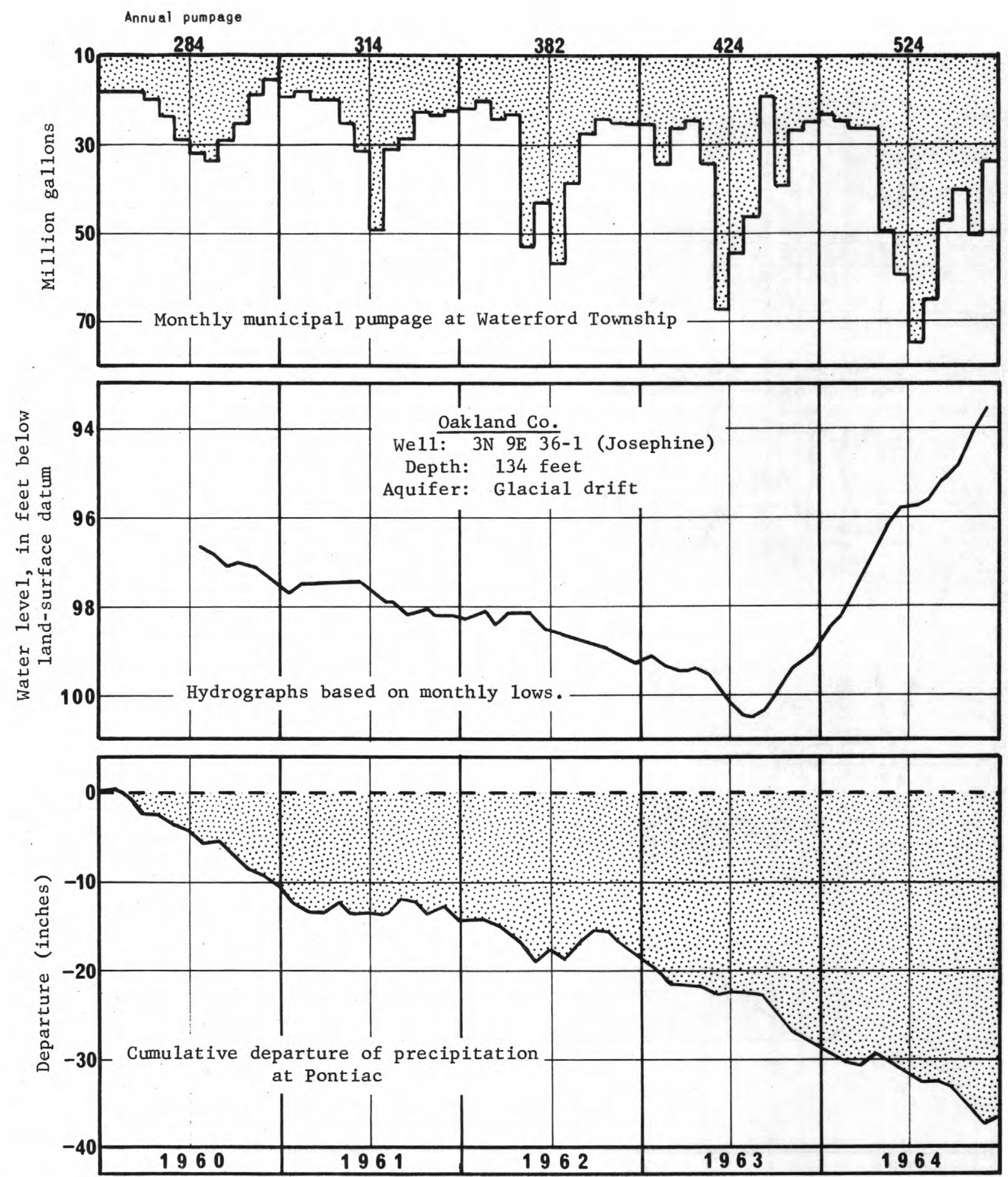

FIGURE $38 .--$ GRAPHS OF WATER LEVELS, PUMPAGE, AND PRECIPITATION, WATERFORD TOWNSHIP, 1960-64.

Despite increased pumpage, and deficient precipitation water levels rose in response to the discontinuance of pumpage by the neighboring city of Pontiac. 
Water supply -- 13 we11s, 85-327. feet deep, tapping the glacial drift throughout the township.

Yie1d of we1ls in gallons per minute -- 300-1,750.

Specific capacity of we1ls in gallons per minute per foot of drawdown - 26-88.

Pumpage in 1964 -- 524 million gallons.

Storage facilities -- 50,000 gallons and 75,000 gallons elevated.

Quality of water -- Hardness 283-300 ppm

Iron $\quad 1.4-2.3 \mathrm{ppm}$

Treatment -- Phosphate and chlorination on some individua1 we11s.

Population served -- estimated 18,000.

Per capita use -- 80 gallons per day

Ground-water conditions -- Water levels rose another five feet in the observation wel1 (fig. 38) despite a 100 million gallon increase in pumpage and continued deficiencies of precipitation. The rise since 1963 is the result of the discontinuance of pumping of ground water by the City of Pontiac in 1963.

Work was begun in 1964 to tie into the township water system all subdivision public supplies in the township, and to add additional elevated storage of $1 \frac{1}{2}$ million gallons. 


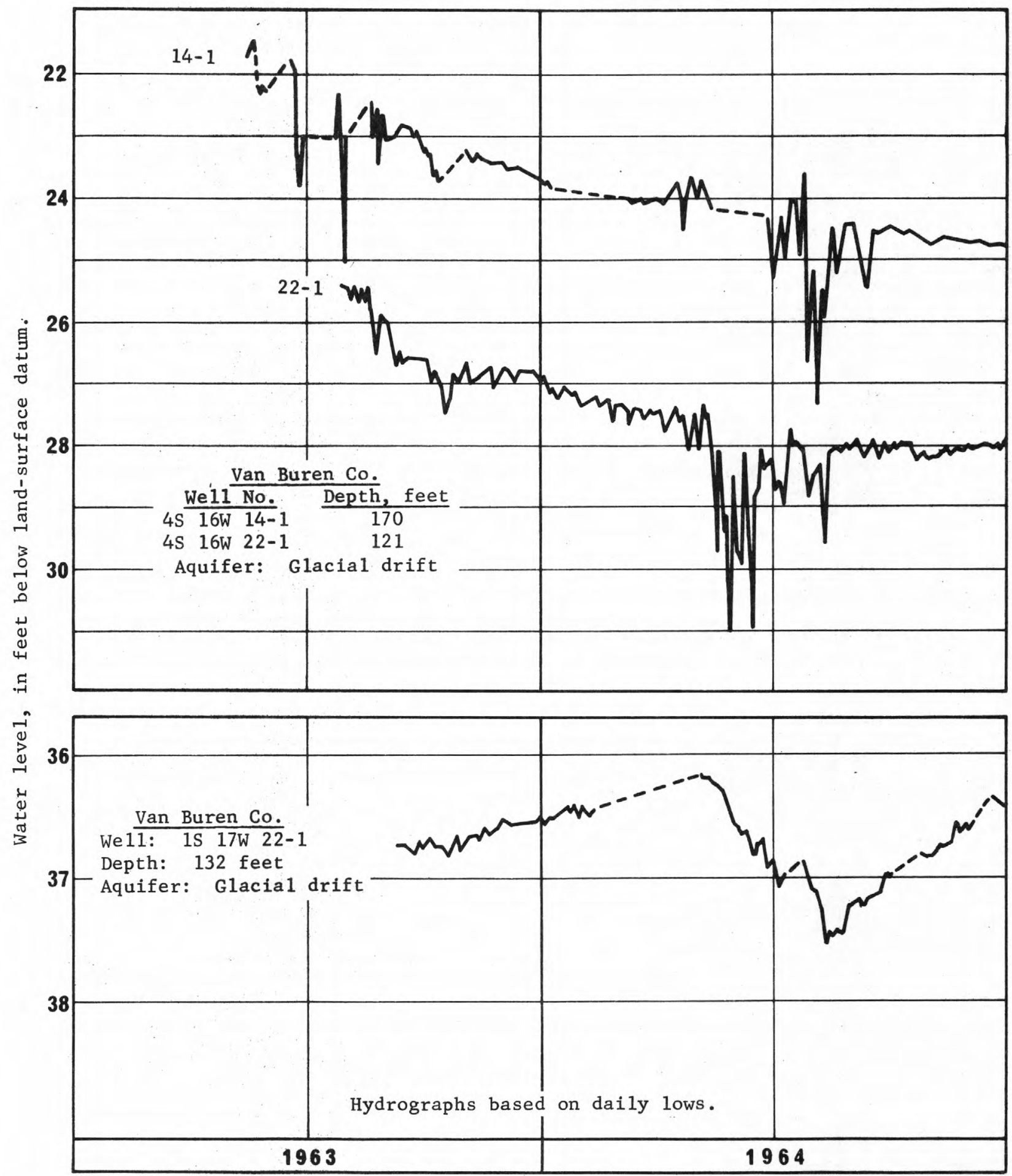

FIGURE 39.--GRAPHS OF WATER LEVELS IN THREE WELIS EQUIPPED WITH RECORDING GAGES, VAN BUREN COUNTY, 1963-64.

The two wells in the upper part of the figure are

affected by irrigation and industrial pumpage. 
Most of the public and private water supplies in the County are obtained from wells finished in glacial drift except at South Haven where water is pumped from Lake Michigan. Some irrigation we1ls yield over 1,000 gallons per minute. The water from wells is generally hard and locally high in iron content, but is otherwise suitable for most uses.

Eight observation wells, three of which are equipped with recording gages, are maintained in the County.

Two of these recording gages (fig. 39) reflect conditions in the heavily irrigated area around Keeler located in the southwest part of the County. The heavy irrigation and also some industrial pumpage causes sharp fluctuations in the water levels. The bottom graph of figure 39 reflects changes in water level owing to natural climatic conditions in the area south of South Haven.

The water level declines in the two wells (14-1 and 22-1) in the Keeler area were mostly the result of large deficiencies of precipitation. In the South Haven area precipitation was about normal and water levels rose somewhat. However, precipitation at Paw Paw and Bloomingdale ranged from 9 to 6 inches below normal in 1964.

Water levels in four out of the five sma11-diameter wells (fig. 40) measured monthly in the County continued to decline as the result of the general precipitation deficiencies.

For additional information, see report "Water Resources of Van Buren County, Michigan" released in 1964 by the Michigan Department of Conservation as Water Investigation 3 . 


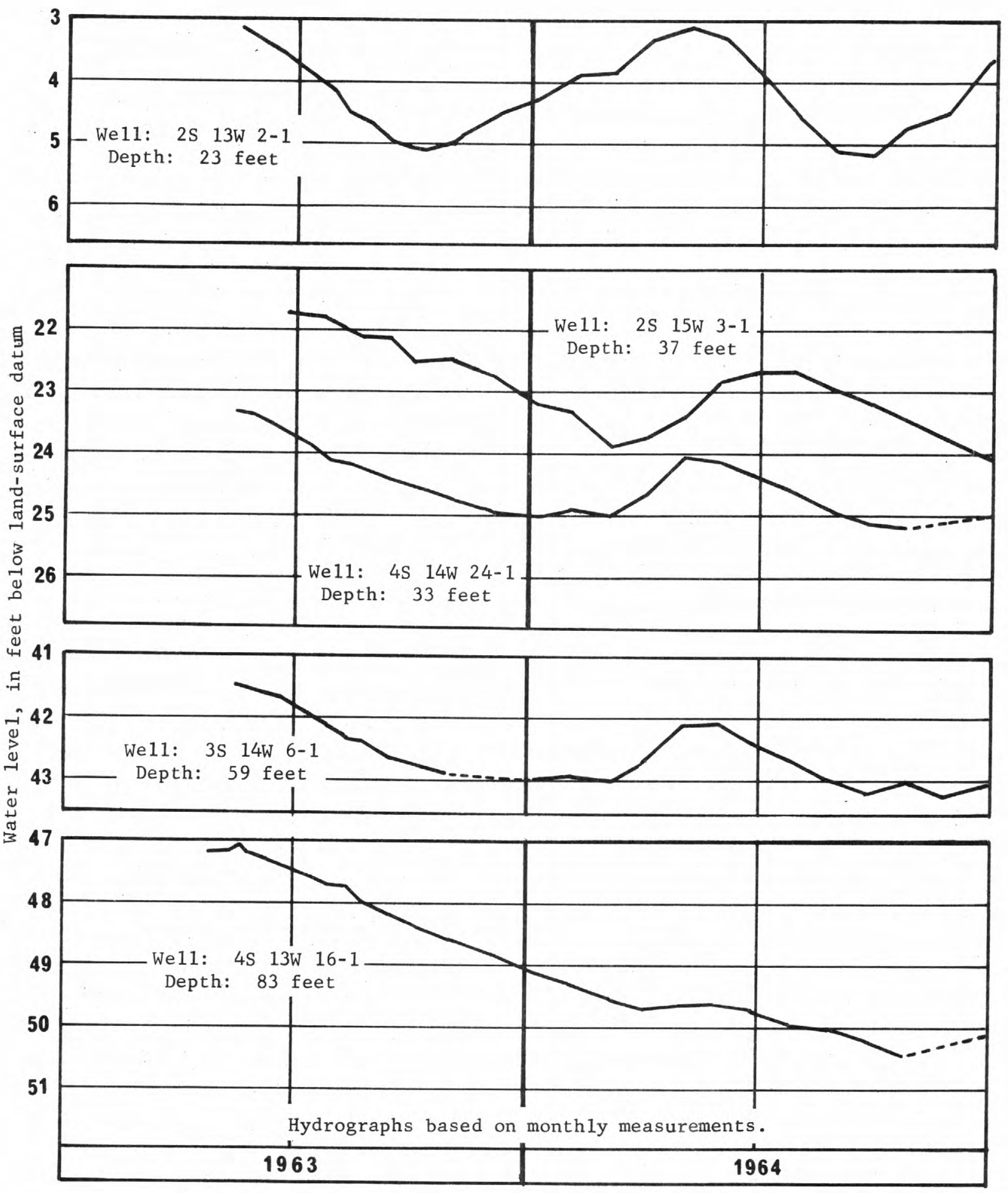

FIGURE 40.--GRAPHS SHOWING WATER LEVELS IN FIVE WELLS TAPPING THE GLACIAL DRIFT IN VAN BUREN COUNTY, 1963-64.

Water levels continued to decline in 1964 as the result of precipitation deficiencies. 

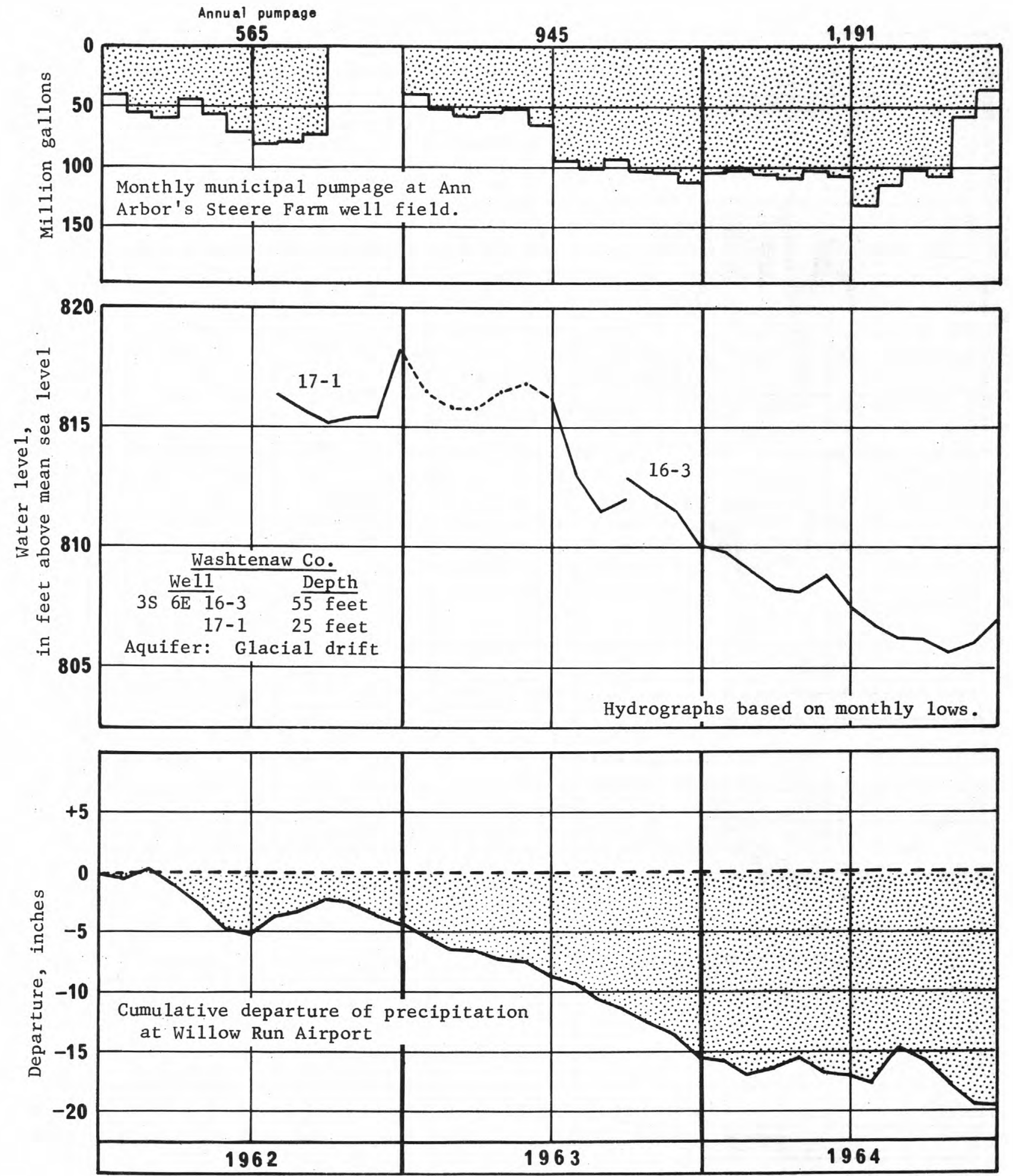

FIGURE 41 .--GRAPHS OF WATER LEVELS IN TWO WELIS, GROUND-WATER PUMPAGE, AND PRECIPITATION, ANN ARBOR, 1962-64.

Water levels continued to decline as a result of increased pumpage and precipitation deficiencies. 
Water supply -- Four we11s, 91-196 feet deep, finished in glacial drift and water from the Huron River.

Yield of we 1ls in gallons per minute -- 2-3,000.

Specific capacity of we11s in ga11ons per minute per foot of drawdown -- about 550-650.

Pumpage in 1964 -- Total 3,974 million gallons - surface water and ground water. (1,430 million gallons ground water). Maximum day -- 7.65 million gallons of ground water.

Storage facilities -- Treatment plant: 6,057,000 gallons. Ground leve1 on system: 2,000,000 ga1lons. Elevated storage: $1,000,000$ gallons.

Quality of water -- Treated water: Hardness $76 \mathrm{ppm}$; Iron 0. Ground water: Hardness 370-405 ppm; Iron 0.25-2.4.

Treatment -- Lime and soda ash softening, fluoridation, chlorination and filtration.

Population served -- 67,340 . Per capita use -- *58 gallons per day. (*For ground water only. 162 gallons per day total surface water and ground water.).

Ground-water conditions -- Water levels in the observation we11 continued to decline as the result of increased pumpage and continued deficiencies of precipitation. Levels have fallen about 11 feet in the 1963-64 period. The low stages of about 16 feet below land surface occurred in 1964 . Ground-water pumpage at the Steere Farm well field area in 1964 was double the amount pumped in 1962. The observation wel1 water levels and the pumpage shown in figure 41 are for this Steere Farm well field area several miles south of Ann Arbor. Some municipal production wells are located within the city limits. About $64 \%$ of the water pumped in 1964 was from the Huron River. 

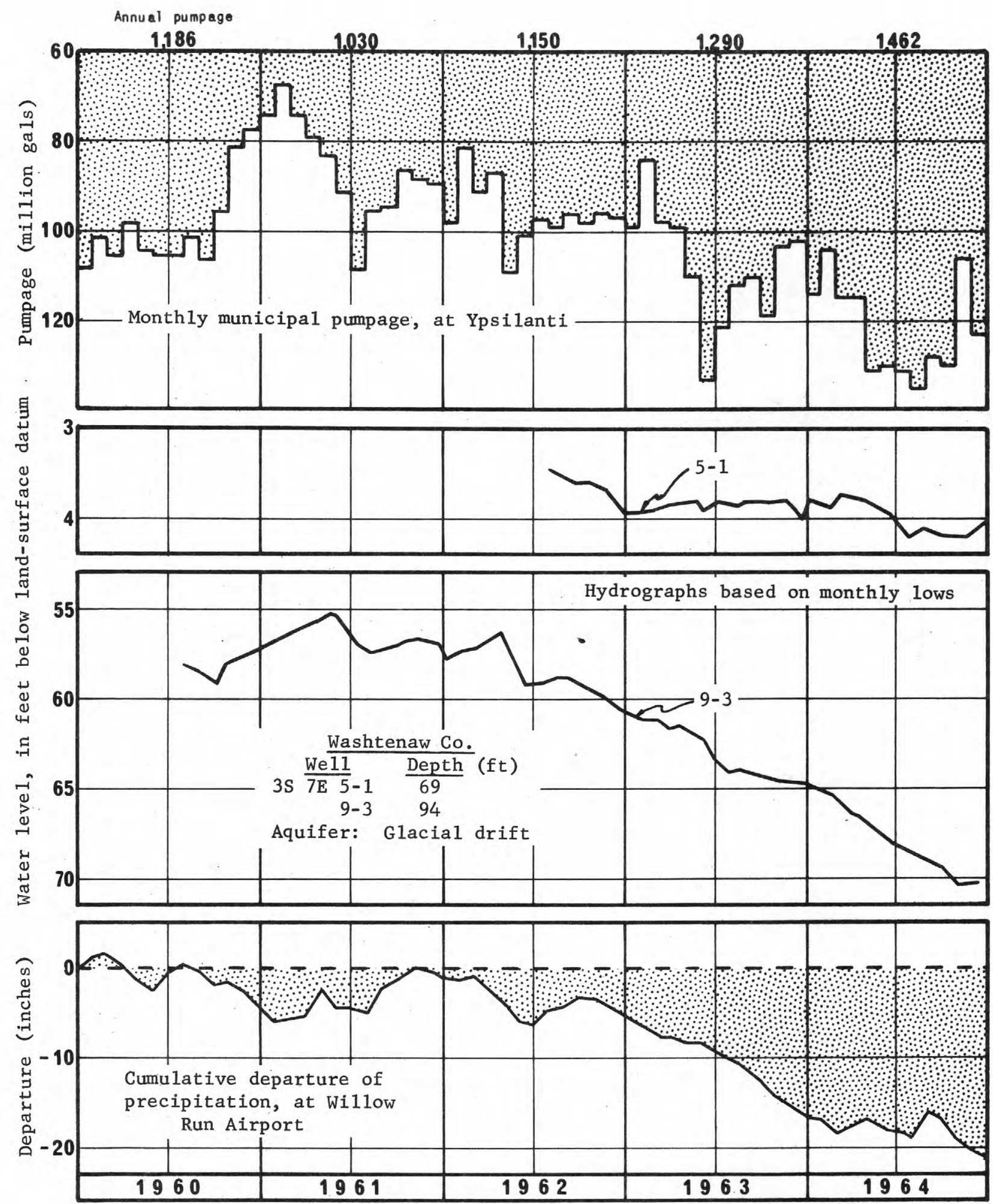

FIGURE 42 .--GRAPHS OF WATER LEVELS IN TWO WELLS, PUMPAGE, AND PRECIPITATION, YPSILANTI, 1960-64.

Water levels fell to record-low stages in we11 9-3 in 1964 when pumpage increased $13 \%$ and precipitation was deficient for the third consecutive year. 
Water supply -- Water is obtained from five we11s, 87-102 feet deep, finished in glacial drift.

Yield of we11s in gallons per minute -- 4.5 average for 5 we 11 s -- we 11 s not metered individua11y.

Specific capacity of we11s in gallons per minute per foot of drawdown -Estimated 25-180.

Pumpage in 1964 -- 1,462 million gallons. Maximum day -- 4.91 million gallons.

Storage facilities -- Treated water at plant 2,000,000 gallons. Elevated storage $1,000,000 ; 250,000$.

Quality of water -- Treated water: Hardness $86 \mathrm{ppm}$; Iron 0. Raw water: Hardness 305-320 ppm Iron $\quad 1.2-1.6 \mathrm{ppm}$ Fluoride $0.3 \mathrm{ppm}$

Treatment -- Lime softening.

Population served -- estimated 28,000 (1964).

Per capita use -- 143 gallons per day.

Ground-water conditions -- Levels continued to decline in 1964 in wel1 9-3 (fig. 42) as pumpage increased and precipitation deficiencies continued to accumulate. A water-level decline of 41 feet has been recorded since 1945 (table 2) in we11 9-3. However, stages remained relatively steady in well 5-1 (fig. 42). This observation well is located over a mile from the City's pumping wells and is close to the Huron River. It is reported that a production well will be drilled at this site in 1965 . 

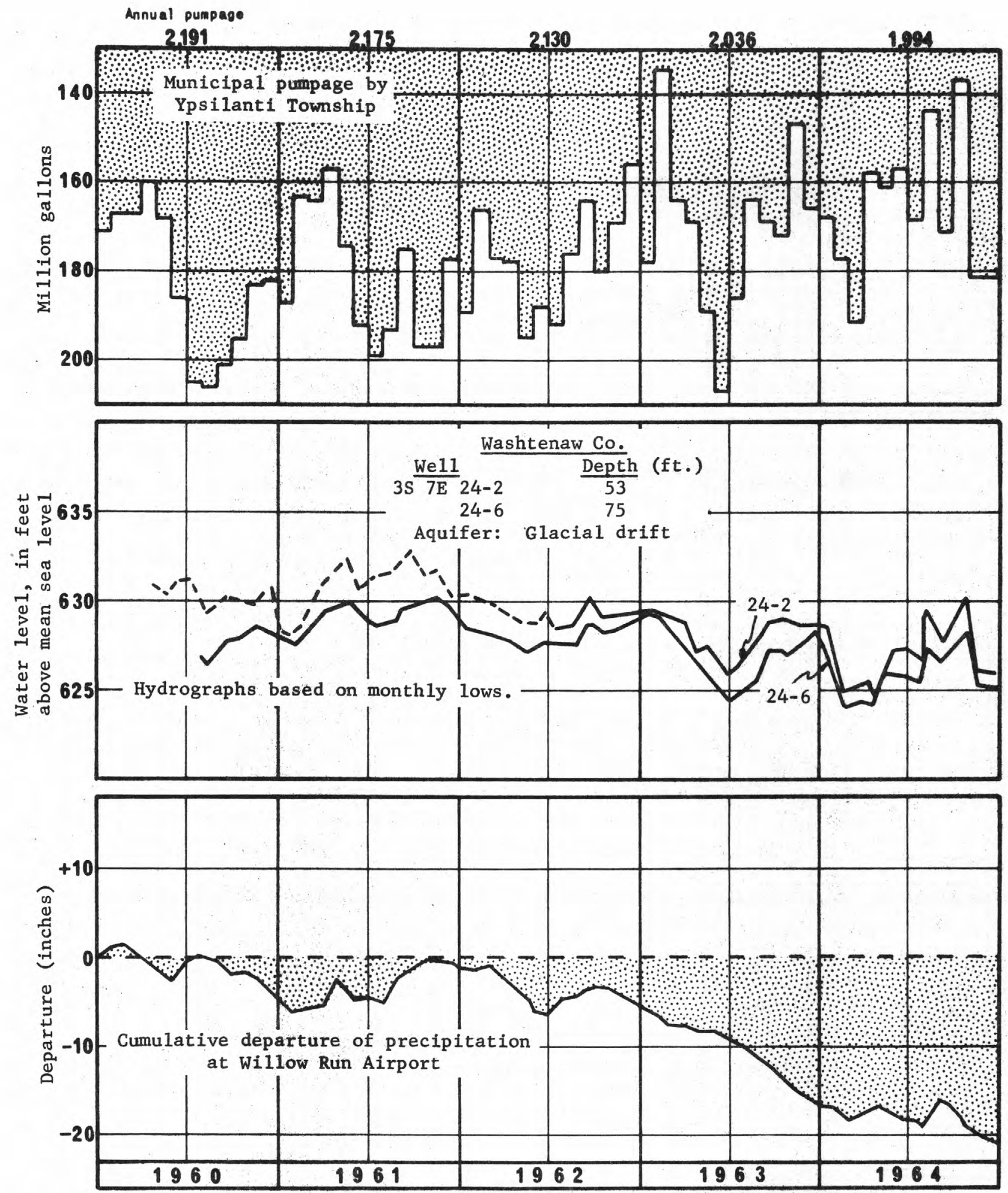

FIGURE 43.--GRAPHS OF WATER LEVELS IN TWO WELLS, PUMPAGE, AND PRECIPITATION, YPSILANTI TOWNSHIP, 1960-64.

Water levels fell to record-low stages in late winter in response to increased pumpage during that period. 
Water supply -- Five we11s, 50-90 feet deep, finished in glacial drift.

Yield of wells in gallons per minute -- 700-1,000:

Pumpage in $1964--1,994$ million gallons.

Storage facilities -- Treated water at plant 1,618,000 gallons. $400,000-100,000-75,000$ elevated ga11ons.

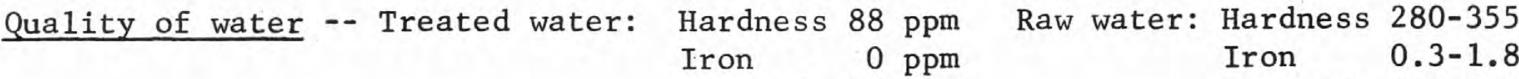
Fluoride $0.1 \mathrm{ppm} \quad$ Fluoride $0.1-0.6$

Treatment -- Lime softening, chlorination.

Population served -- estimated 30,000 (1964).

Per capita use -- 181 gallons per day.

Ground-water conditions -- Periods of heavy pumpage caused drops in water levels. In early 1964 water levels fell to new lows of record as a result of the large withdrawals early in the year (fig. 43). However, precipitation deficiencies are also contributing to the decline of water levels. The effect of precipitation is particularly evident in 1961 when water levels showed a net gain for the year as a result of aboveaverage rainfall despite heavy pumpage in that year.

Records of wells 3S 7E 24-1 through 24-6 (Washtenaw County, table 2 ) show that levels have fallen 15 to 28 feet in these observation wells below the highs observed in the 1943-50 period. 

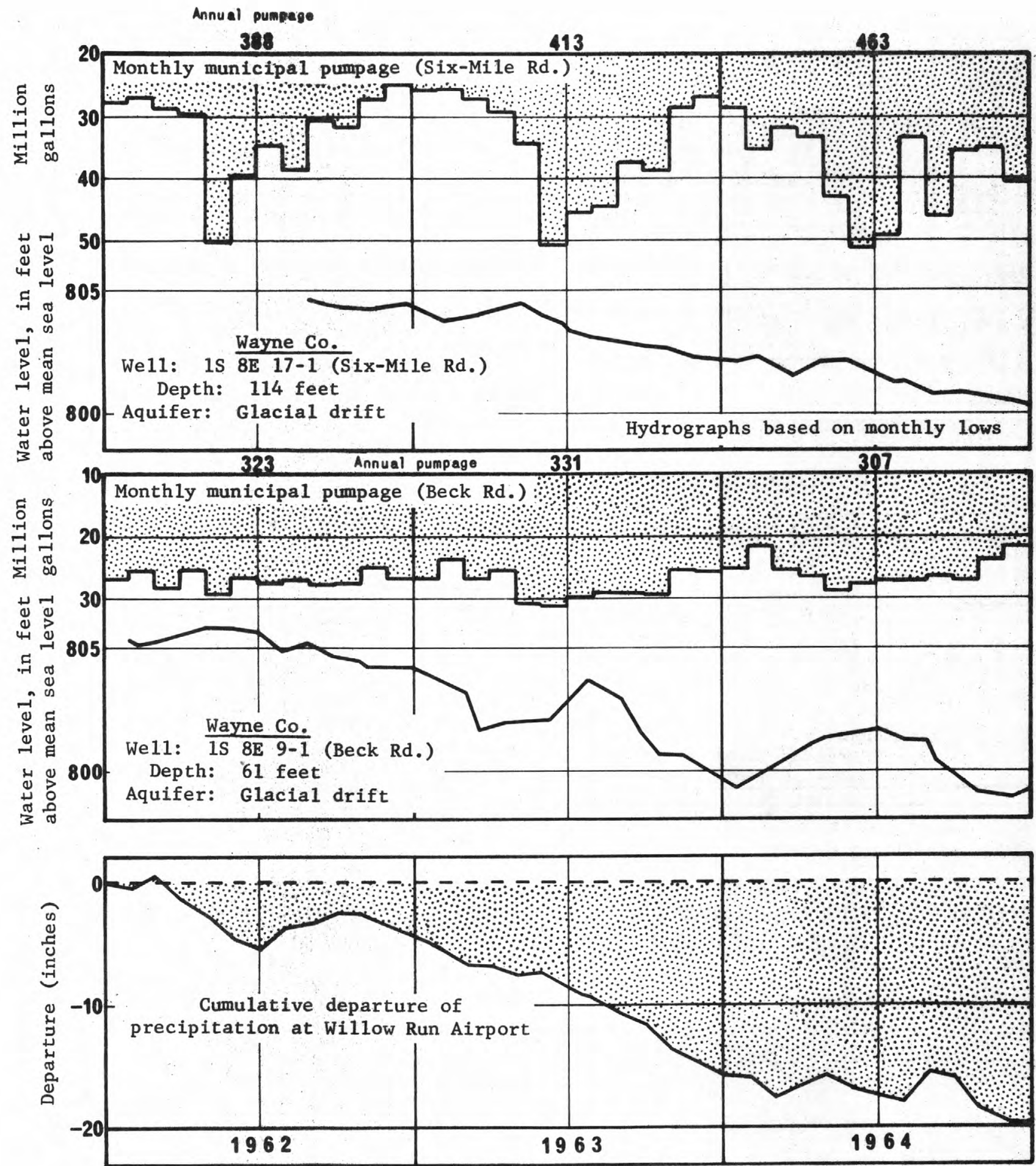

FIGURE 44 . --GRAPHS SHOWING WATER LEVELS IN TWO WELLS, PUMPAGE, AND PRECIPITATION, PLYMOUTH, 1962-64.

Much of the declining trend of water levels is the result of deficient precipitation. 
Water supply -- Six we11s, 20-110 feet deep, finished in glacial drift and located at three we11 fields.

Yield of wells in gallons per minute -- 500-2,400.

Specific capacity of we11s in ga11ons per minute per foot of drawdown -- 84-700.

Pumpage in 1964 - 828 million gallons.

Maximum day - 4.17 million gallons.

Storage facilities -- 150,000, 250,000 and 1,500,000 gallons elevated storage tanks.

$\begin{array}{rc}\text { Quality of water -- Hardness } & 325-395 \mathrm{ppm} \\ \text { Iron } & 0.1-1.1 \mathrm{ppm} \\ \text { Fluoride } & 0.2-0.4 \mathrm{ppm} \\ \text { Chloride } & 31-59 \mathrm{ppm}\end{array}$

Treatment -- Chlorination, fluoridation, phosphate.

Population served -- estimated 11,000 (1964).

Per capita use -- 207 gallons per day.

Ground-water conditions -- Ground-water leve1s continued to decline in 1964 (fig. 44) as precipitation deficiencies continued to accumulate and pumpage increased. The decline was less at the Beck Road field where pumpage decreased and more at 6-Mile Road where pumpage increased by about $12 \%$. The single we11 at the Six-Mile Road Station pumps over 2,000 gpm when in operation and the monthly pumpage varies considerably. The Beck Road Station pumps about a million gallons daily and the monthly pumpage is relatively steady. 


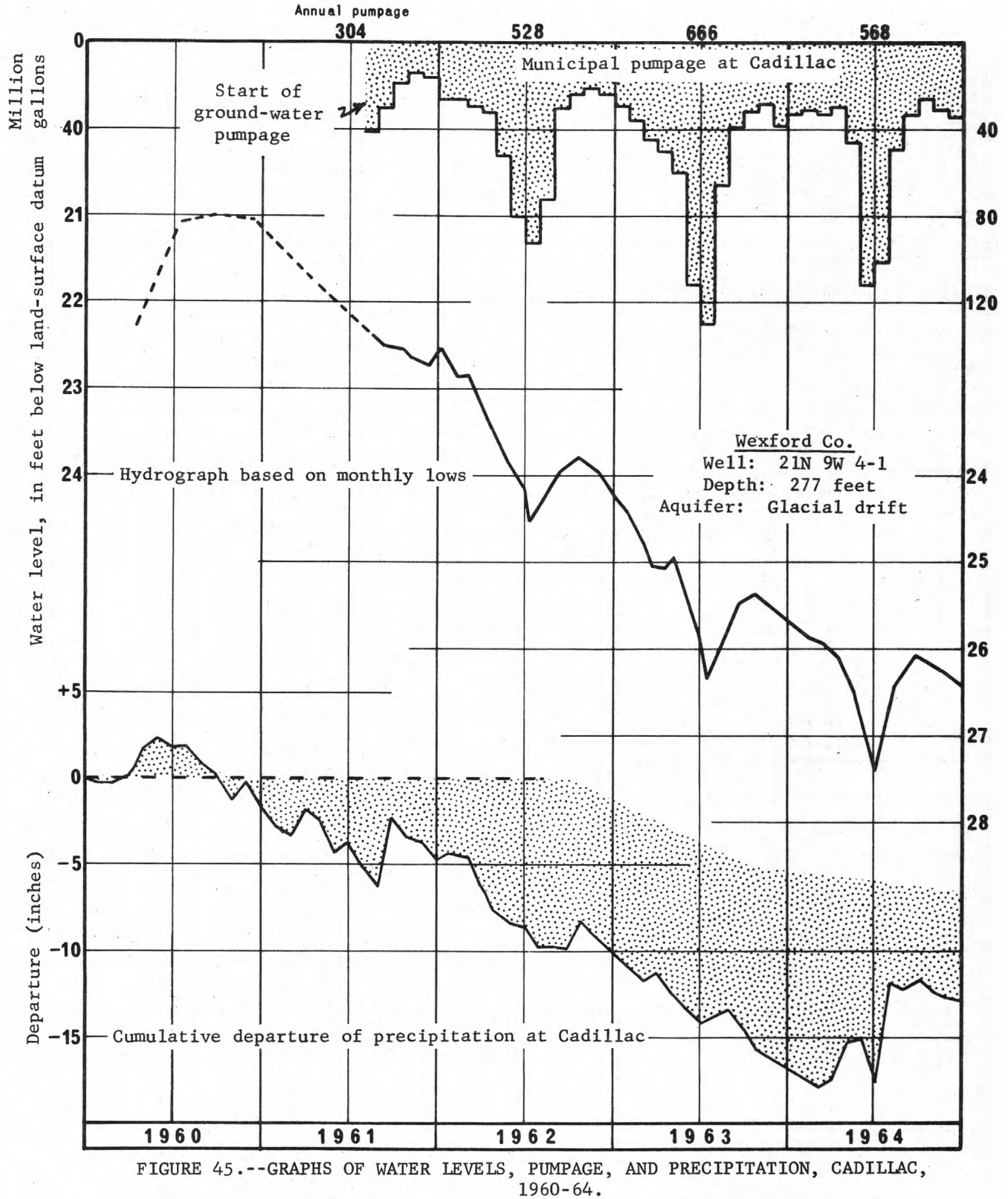

Water levels continued to decline in 1964 despite above-average precipitation and reduced pumpage. 
Water supply -- Six wells 300 to 382 feet deep obtain water from the glacial drift aquifer.

Yield of wells in gallons per minute -- Nos. 1, 2, 4 and $6-1,400$; no. 3 - 750; no. $5-1,000$.

Specific capacity of wells in gallons per minute per foot of drawdown -- No. 1 18 ; no. 2 - 25 ; no. $3-13$; no. $4-42$; no. $5-31$; no. $6-42$.

Pumpage in 1964 -- 568 million ga11ons. Maximum day -- 7.30 million gallons.

Storage facilities -- 1 million gallons elevated.

Quality of water -- Hardness 108-112 ppm

$$
\text { Iron } 0.4 \quad \mathrm{ppm}
$$

Treatment -- Chlorination.

Population served -- 10, 112 .

Per capita use -- 153 gallons per day。

Ground-water conditions -- Cadillac formerly obtained its public supply from Lake Cadillac. Since the start of the ground-water system in mid-1961, ground-water levels in an observation wel1, located about $\frac{1}{2}$ mile southeast of the city's well field, have fallen about four feet (fig. 45).

Much of the decline, however, was the result of deficient precipitation.

In 1964 above-average precipitation and decreased pumpage resulted in only about one-half a foot of decline. The figure of 304 million gallons in 1961 (fig. 45) represents the total pumpage of ground and surface water in that year. 



\section{GROUND-WATER RESOURCES INVESTIGATIONS IN MICHIGAN}

REPORTS OF INVESTIGATIONS

Selected references on water in Michigan are given below; many of them are available for reference at one of the offices listed in the Preface of this report and at the larger public and university libraries. A more complete listing of Geological Survey reports and their availability is given in a pamphlet "Geologic and Water-Supply Reports and Maps -- Michigan". Price lists of available publications of the Michigan Geological Survey are available from that agency.

\section{SEIECTED REFERENCES}

\section{Publications of the U. S. Geological Survey}

\section{Water-Supp1y Papers}

1078 Ground-water supplies of the Ypsilanti area, Michigan, by C. L. McGuinness, O. F. Poindexter, and E. G. Otten, 1949.

1299 The industrial utility of public water supplies in the United States, 1952, pt. 1, States east of the Mississippi River, by E. W. Lohr and S. K. Love, 1954.

1499-E Water resources of the Flint area, Michigan, by S. W. Wiita1a, K. E. Vanlier and R. A. Krieger, 1960.

1619-E Ground-water resources of the Alma area, Michigan, by K. E. Vanlier, 1961.

1691 Ground-water contamination and lega1 controls in Michigan, by Morris Deutsch, 1961.

1800 The role of ground water in the national water situation, by C. L. McGuinness, p. 412-427, 1963.

\section{Circulars}




\section{Circulars.--Continued:}

Water resources of the Grand Rapids area, Michigan, by G. J. Strame1, C. 0. Wisler and L. B. Laird, 1954.

Open-file reports of the U.S. Geological Survey

Deutsch, Morris, Phenol contamination of an artesian aquifer at Alma, Michigan: 1962.

Deutsch, Morris, and Vanlier, K. E., Ground water for Michigan's future: 1961.

\section{Other publications}

Brown, E. A.; and Stuart, W. T., 1951, Ground-water resources of the glacial deposits in the Bessemer area, Michigan: Mich. Geol. Survey Prog. Rept. $14,1951$.

Deutsch, Morris, 1956, Effects of dissemination of radioactive materials on water resource conservation with special reference to Michigan: Mich. State Univ. Agr. Exp. Sta. Water Bu11. 2 .

1961, Hydrogeologic aspects of ground-water pollution: Water We11 Jour., V. 15, no. 9.

1961, Incidents of chromium contamination of ground water in Michigan: U. S. Public Health Service Tech. Rept. W61-5, p. 98-104.

- 1962, Controlled induced-recharge tests at Kalamazoo, Michigan: Jour. Am. Water Works Assoc., V. 54, no. 2, p. 181-196, Feb.

- Burt, E. M., and Vanlier, K. E., 1958 Summary of ground-water investigations in the Holland area, Michigan: Mich. Geol. Survey Prog. Rept. 20.

, Vanlier, K. E., and Giroux, P. R., 1960, Ground-water hydrology and glaclal geology of the Kalamazoo area, Michigan: Mich. Geol. Survey Prog. Rept. 23.

Ferris, J. G., and others, 1954, Ground-water resources of southeastern Oakland County. Mlchigan: Mich. Geol. Survey, Prog. Rept. 16.

Giroux, P. R., 1957, Summary of ground water conditions in Michigan, 1956: Mich. Geo1. Survey Water Supply Rept. 1 . 
Giroux, P. R., 1958, Summary of ground-water conditions in Michigan, 1957: Mich. Geol. Survey Water Supply Rept. 2 .

, and Thompson, Ted, 1960, Summary of ground-water conditions in Michigan, 1958: Mich. Geo1. Survey Water Supply Rept. 3. , 1960, Summary of ground-water conditions in Michigan, 1959: Mich. Geo1. Survey Water Supp1y Rept. 4. , 1961, Summary of ground-water conditions in Michigan, 1960: Mich. Geol. Survey Water Supply Rept. 5.

Giroux, P. R., 1962, Summary of ground-water conditions in Michigan, 1961: Mich. Geol. Survey Water Supply Rept. 6.

, and Huffman, G. C., 1963, Summary of ground-water conditions in Michigan, 1962: Mich. Geol. Survey Water Supply Rept. 7. Michigan, 1963: Open-file report.

Giroux, P. R., Hendrickson, G. E., Stoimenoff, L. E. and Whetstone, G. W., 1964, Water resources of Van Buren County, Michigan: Mich. Geol. Survey Water Investigation No. 3.

Hendrickson, G. E., and Doonan, C. J., 1965, Ground-water resources of Dickinson County, Michigan: Mich. Geol. Survey, Water Investigation No. 5 (in press).

Michigan Department of Health, 1961, Data on Public Water Supplies in Michigan: Mich. Dept. of Health Eng. Bu11. 4.

Mozola, A. J., 1953, A survey of ground-water resources in Oakland County, Michigan: Mich. Geol. Survey Occasional Papers for 1954 on the Geology of Michigan, Pub1. 48.

Sinclair, W. C., 1959, Reconnaissance of the ground-water resources of Schoo1craft County, Michigan: Mich. Geol. Survey Prog. Rept. 22.

1960, Reconnaissance of the ground-water resources of Delta County, Michigan: Mich. Geol. Survey Prog. Rept. 24.

Stuart, W. T., 1945, Ground-water resources of the Lansing area, Michigan: Mich. Geo1. Survey Prog. Rept. 13.

, Brown, E. A., and Rhodehame1, E. C., 1954, Ground-water investigations of the Marquette iron-mining district, Michigan: Mich. Geol. Survey Tech. Rept. 3 . 
Stuart, W. T., and Sta11man, R. W., 1945, Ground-water resources of the Benton Harbor area, Michigan: Mich. Geol. Survey Prog. Rept. 12.

, Theis, C. V., and Stanley, G. M., 1948, Ground-water problems in the Iron River District, Michigan: Mich. Geo1. Survey Tech. Rept. 2.

Terwilliger, F. W., 1952, The glacial geology and ground-water resources of Van Buren County, Michigan: Mich. Geol. Survey Occasional Papers for 1954 on the Geology of Michigan, Pub1. 48.

Vanlier, K. E., 1959, Reconnaissance of the ground-water resources of Luce County, Michigan: Mich. Geol. Survey Prog. Rept. 21.

, and Deutsch, Morris, 1958, Reconnaissance of the ground-water resources of Chippewa County, Michigan: Mich. Geol. Survey Prog. Rept. 17.

, and Deutsch, Morris, 1958, Reconnaissance of the ground-water resources of Mackinac County, Michigan: Mich. Geol. Survey Prog. Rept. 19. , 1962, Summary of ground-water investigations in the E1sie area, Michigan: Mich. Geo1. Survey Prog. Rept. 25.

, 1963, Ground water in Alger County: Mich. Geo1. Survey Water Investigation Rept. 1.

, 1963, Ground water in Menominee County: Mich. Geol. Survey Water Investigation Rept. 2.

, 1964, Ground-water resources of the Battle Creek area, Michigan:

Mich. Geol. Survey Water Investigation Rept. 4 (in press).

\section{Water Resources Commission of Michigan River Basin Reports}

Water Resources of the Clinton River Basin, 1953.

Water resource conditions and uses in the Paw Paw River Basin, 1955 (revised report in 1964).

Water resource condition and uses in the Flint River Basin, 1956.

Water resource condition and uses in the Huron River Basin, 1957.

Water resource condition and uses in the Tittabawassee River Basin, 1960.

Water resource condition and uses in the Upper Grand River Basin, 1961.

Water resource condition and uses in the Shiawassee River Basin, 1963.

Water resource condition and uses in the Maumee River Basin, 1964.

Water resource condition and uses in the River Raisin Basin, 1965. 
Owner: MDC - Mich. Dept. of Conservation; WMP - Wisconsin-Michigan Power Co.; MSHD - Mich. State Highway Department; USFS - U. S. Forest Service; HCMA - Huron-C1inton Metropolitan Authority; BCRC - Branch County Road Commission; KCRC - Kalamazoo County Road Commission

\section{Chief Aquifer:}

Qgd - Glacial drift deposits of Pleistocene (Quaternary) age

Ps - Saginaw Formation of Pennsylvanian age

$\mathrm{Mb}$ - Bayport Limestone of Mississippian age

Mm - Marshall Formation of Mississippian age

Dtb - Thunder Bay Limestone of Middle and Late (?) Devonian age

Ds - Sylvania Sandstone of Middle Devonian age

Ss - Salina Formation of Late Silurian age
Sm - Manistique Dolomite of Middle Silurian age

Or - Limestones of Richmond age (Late Ordovician)

Otb - Black River and Trenton Limestones of Middle Ordovician ag

Op - Prairie du Chien Group of Early Ordovician age (previously designated as Au Train Formation)

m - Munising Sandstone or Cambrian age

e - Rocks of Precambrian age (undifferentiated)

pef - Freda Sandstone of Keweenawan age (Precambrian)

Altitude: Land-surface datum in feet above mean sea leve 1

F - 64: Frequency of measurement in 1964: R - Continuous recorder; D - Daily; W - Weekly; M - Monthly; Q - Quarter1y; S - Semiannual1y; A - Annually

Observed water-leve1 extremes: 1964 measurements underscored are new extremes for entire period of record (in feet below or above ( + ) land surface).

Remarks: P - Water level affected by pumping. Water-level measurements are made by the U. S. Geological Survey unless otherwise noted.

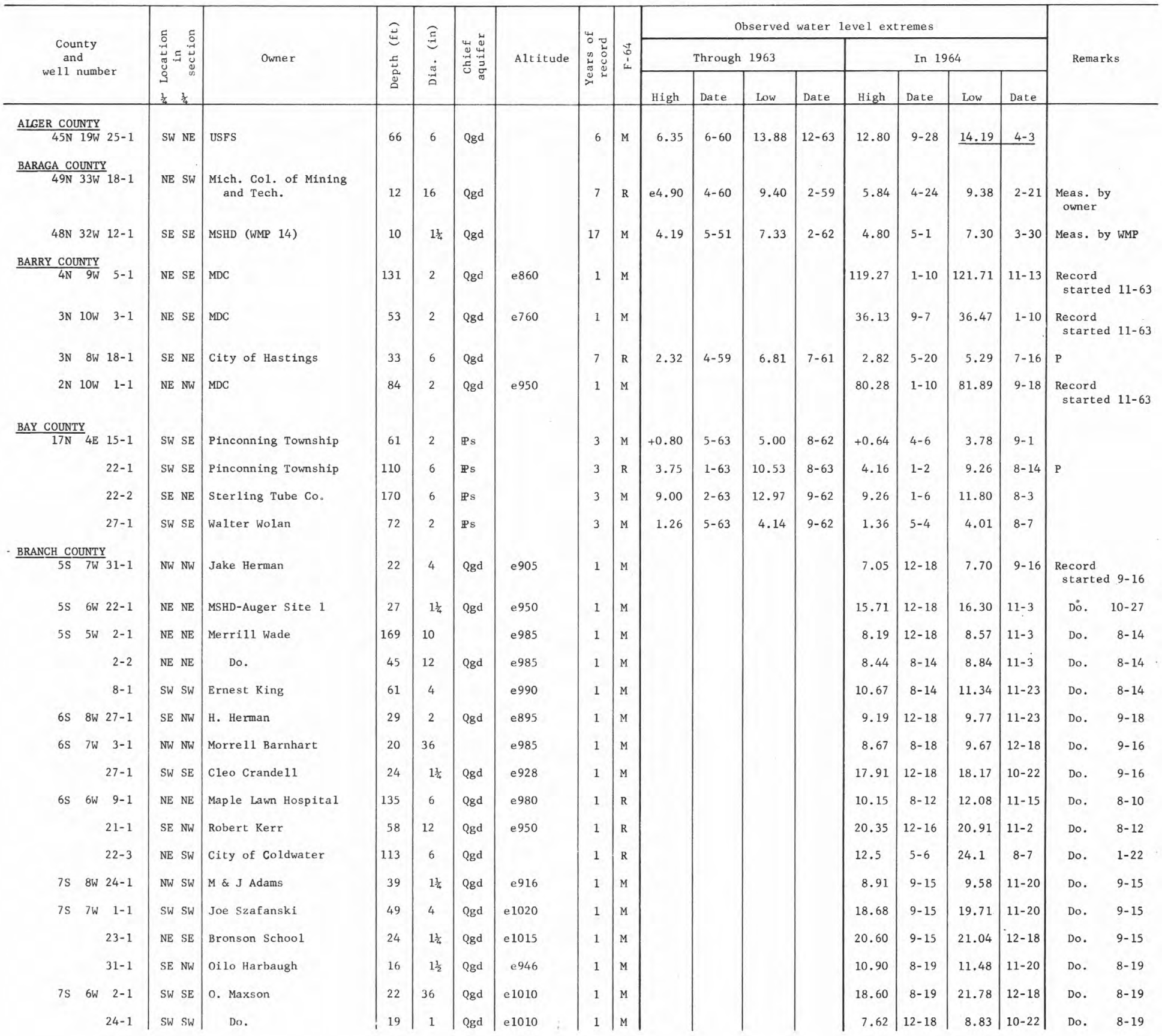




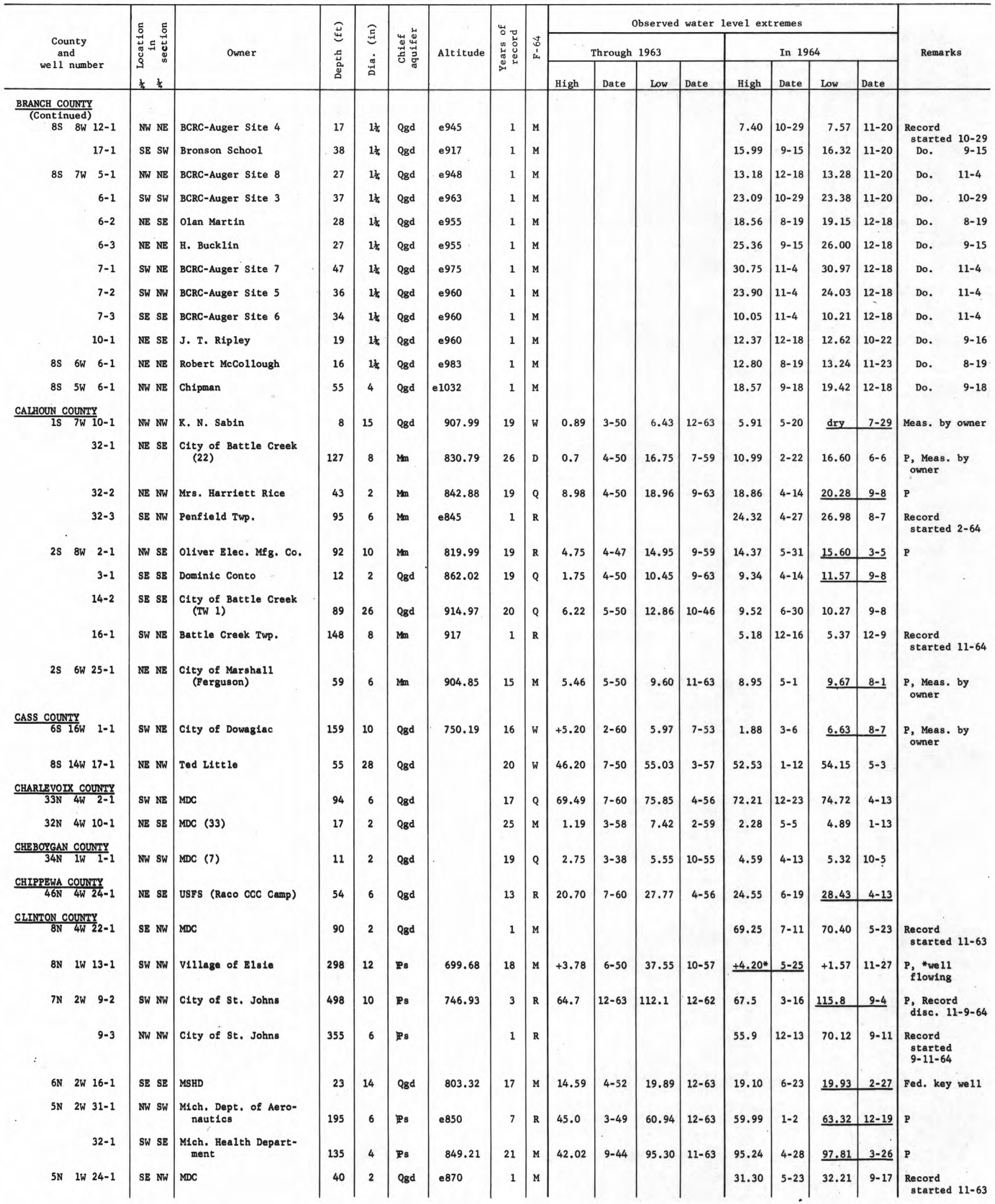




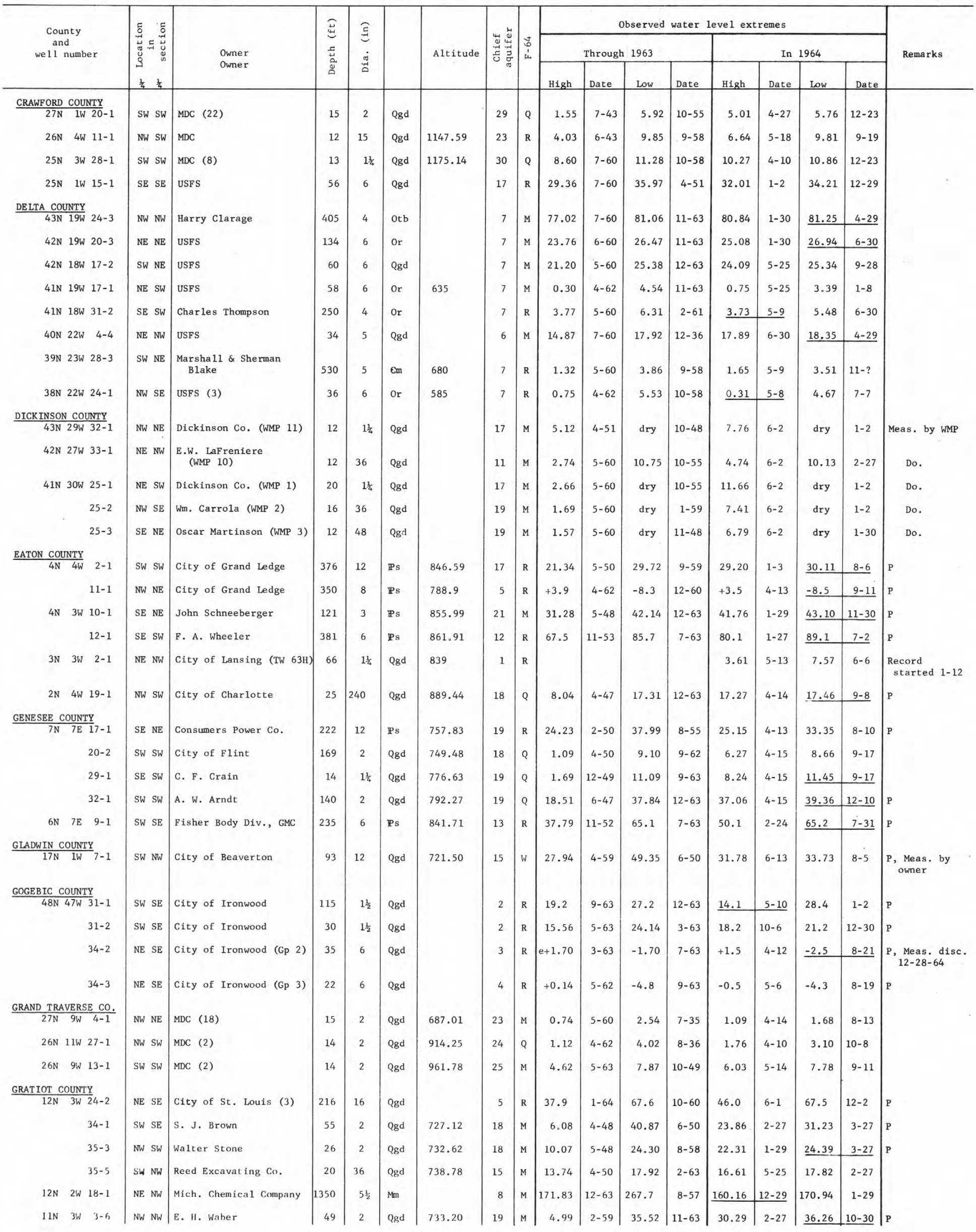




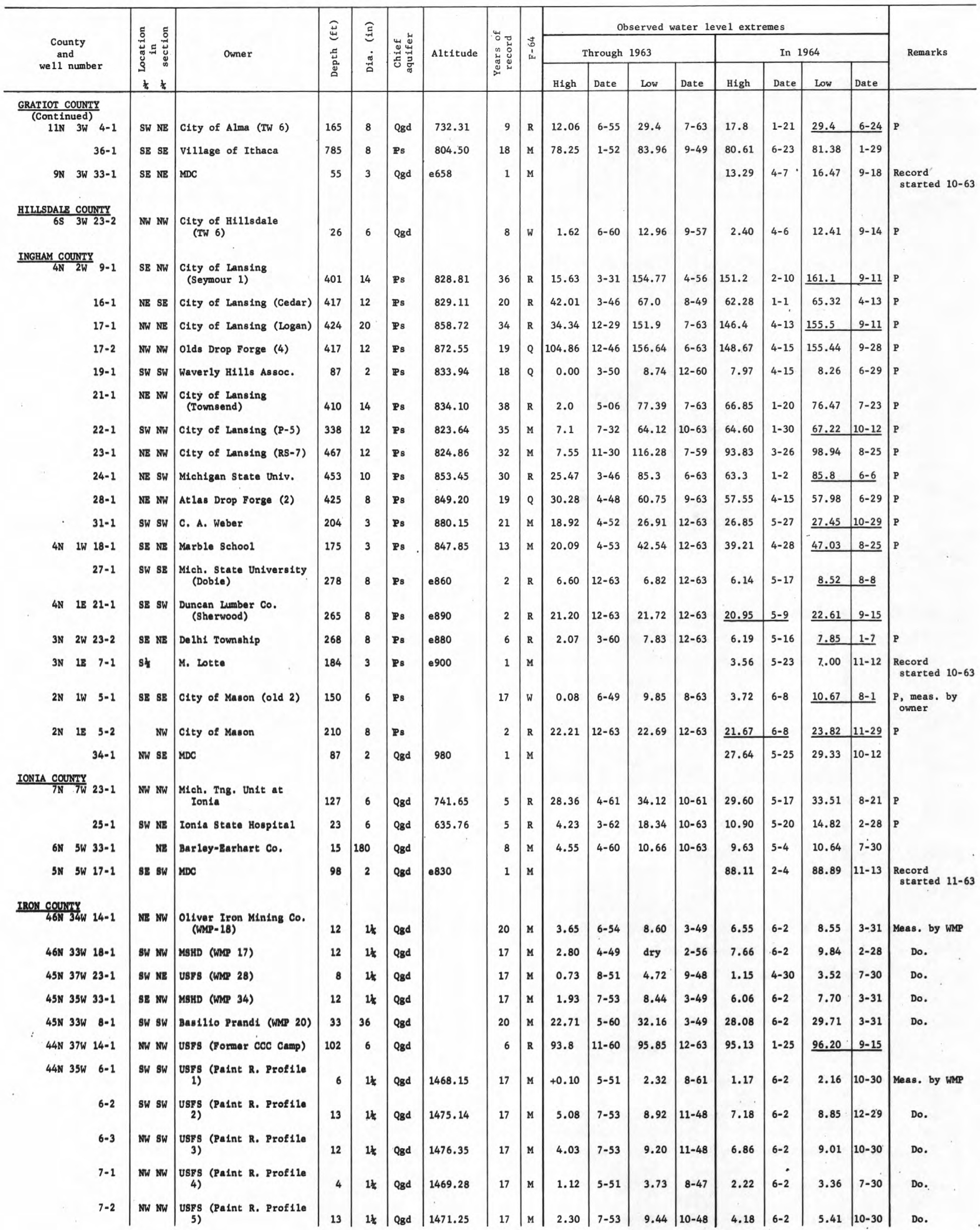




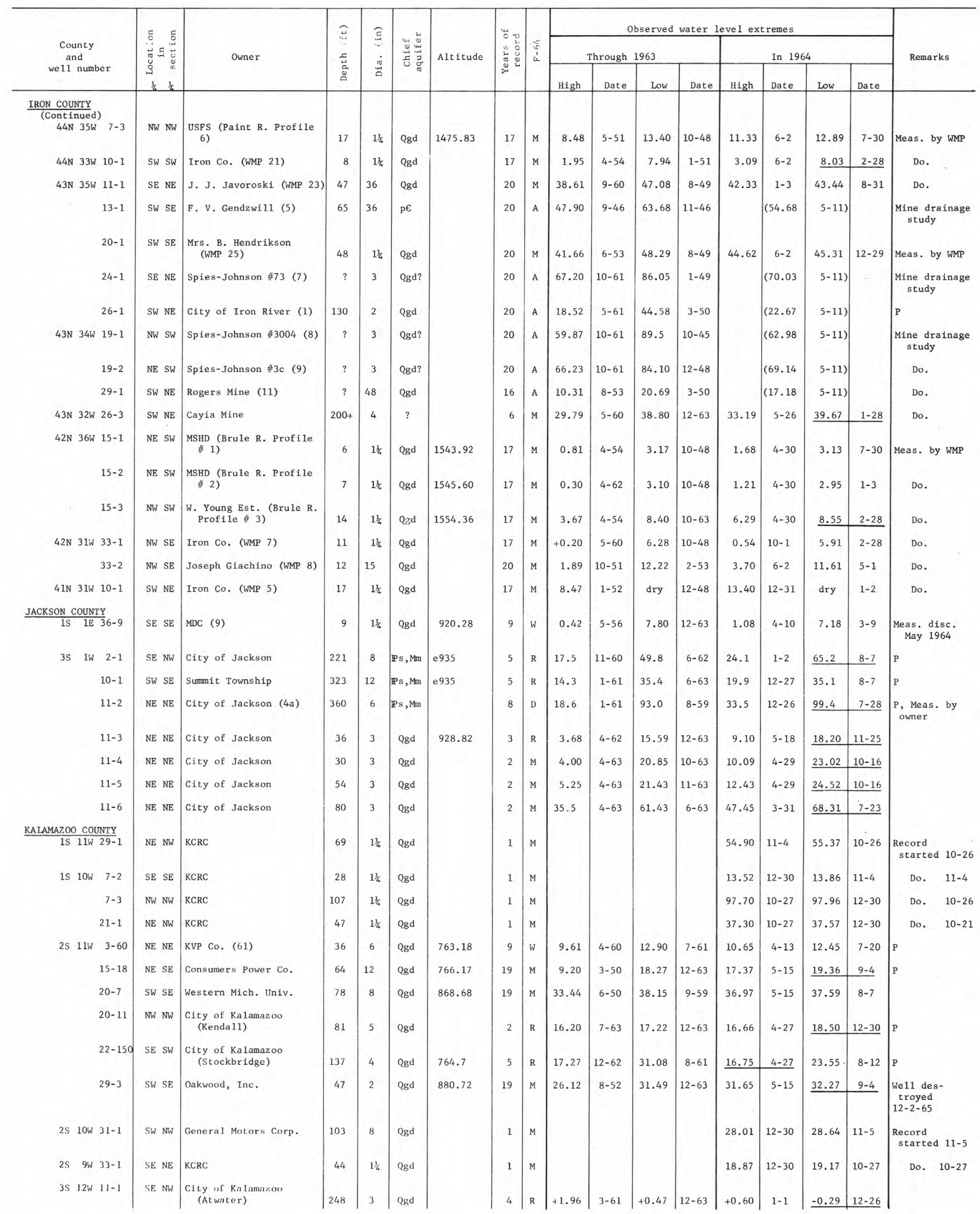




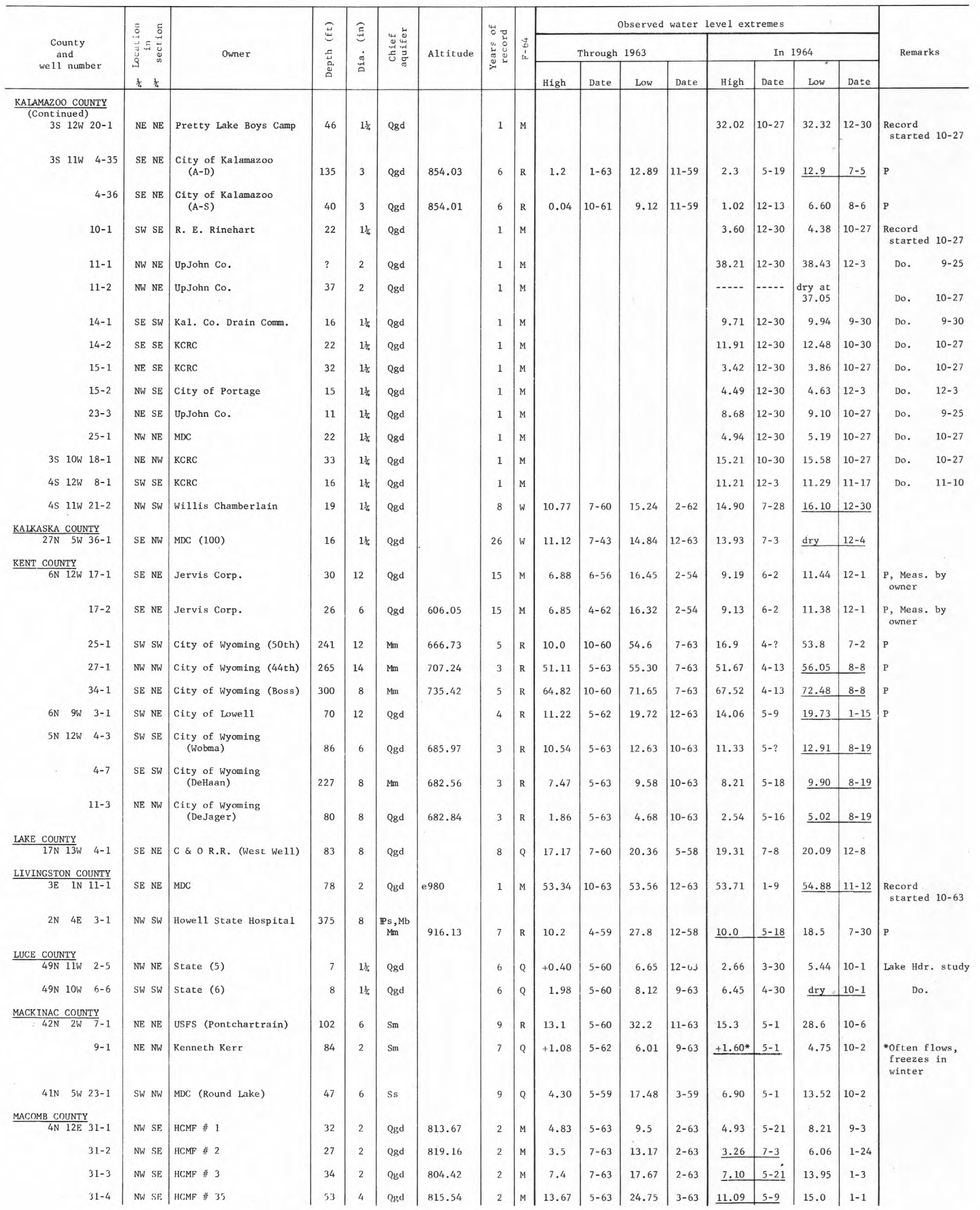




\begin{tabular}{|c|c|c|c|c|c|c|c|c|c|c|c|c|c|c|c|c|c|c|c|}
\hline \multirow{3}{*}{\multicolumn{2}{|c|}{$\begin{array}{l}\text { County } \\
\text { and } \\
\text { we11 number }\end{array}$}} & \multirow{3}{*}{\multicolumn{2}{|c|}{ 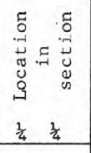 }} & \multirow{3}{*}{ Owner } & \multirow{3}{*}{ 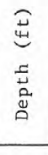 } & \multirow{3}{*}{$\begin{array}{l}\widehat{\Xi} \\
\dot{\Xi} \\
\stackrel{\pi}{a}\end{array}$} & \multirow{3}{*}{ 岁 } & \multirow{3}{*}{ Altitude } & \multirow{3}{*}{ 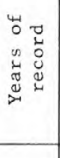 } & \multirow{3}{*}{$\begin{array}{l}1 \\
0 \\
1 \\
1 \\
1\end{array}$} & \multicolumn{8}{|c|}{ Observed water level extremes } & \multirow{3}{*}{ Remarks } \\
\hline & & & & & & & & & & & \multicolumn{4}{|c|}{ Through 1963} & \multicolumn{4}{|c|}{ In 1964} & \\
\hline & & & & & & & & & & & $\mathrm{High}$ & Date & Low & Date & High & Date & Low & Date & \\
\hline \multicolumn{2}{|c|}{$\frac{\text { MACOMB COUNTY }}{\text { (Cont inued) }}$} & & $\mathrm{JE}$ & HCMF \# 36 & 63 & 4 & Qgd & 814.53 & 2 & $\mathrm{R}$ & 13.17 & $5-63$ & 22.92 & $3-63$ & 13.40 & $5-9$ & 17.00 & $1-8$ & \multirow{4}{*}{ Peas. by WMP } \\
\hline $2 \mathrm{~N} 12 \mathrm{E}$ & $1-1$ & SE & $\mathrm{NE}$ & B. H. Tolley & 29 & 48 & Qgd & & 6 & W & 0.50 & $1-60$ & 9.23 & $12-63$ & 1.56 & 4-6 & 9.21 & $1-6$ & \\
\hline$\frac{\text { MANISTEE COUN }}{21 \mathrm{~N} 17 \mathrm{~W}}$ & $\frac{N T Y}{14}-1$ & & NW & City of Manistee & 212 & 6 & & & 2 & $\mathrm{R}$ & 32.43 & $11-63$ & 32.80 & $12-63$ & 32.52 & $4-29$ & 39.3 & $10-15$ & \\
\hline$\frac{\text { MARQUETTE COU }}{49 \mathrm{~N} 30 \mathrm{~W}}$ & $\frac{\text { UNTY }}{22-1}$ & SW & $\mathrm{NE}$ & Marquette Co. (WMP 13) & 17 & $1 \frac{1}{4}$ & Qgd & & 17 & M & 0.64 & $5-51$ & 13.32 & $9-48$ & 7.84 & $5-1$ & 10.10 & $1-30$ & \\
\hline \multirow{2}{*}{\multicolumn{2}{|c|}{48 N 29 W $19-1$}} & SW & SW & $C \& N W R R$ & 31 & $1 \frac{1}{4}$ & Qgd & 1560.39 & 2 & M & & & 5.60 & $11-63$ & 3.22 & $6-18$ & 5.10 & $1-10$ & \\
\hline & & SE & SW & Do. & 32 & $1 \frac{1}{4}$ & Qgd & 1553.48 & 2 & M & 4.08 & $6-25$ & 6.56 & $1-29$ & 4.02 & $5-13$ & 5.53 & $7-21$ & \\
\hline $48 \mathrm{~N} 28 \mathrm{~W}$ & $30-1$ & NW & $\mathrm{NW}$ & Marquette Co. Rd. Comm. & 20 & $1 \frac{1}{4}$ & Qgd & 1566.76 & 2 & M & 3.11 & $5-28$ & 4.62 & $2-25$ & $\underline{2.77}$ & $5-13$ & 4.50 & $2-6$ & \\
\hline $48 \mathrm{~N} 26 \mathrm{~W}$ & $28-1$ & NW & NW & Marquette Co. Airport & 55 & 6 & Qgd & 1416.1 & 3 & M & 16.25 & $7-63$ & 18.64 & $1-63$ & $\underline{16.17}$ & $10-29$ & 16.70 & $7-21$ & \\
\hline & $34-1$ & NE & $\mathrm{SE}$ & Marquette Co. Rd. Corm. & 31 & $1 \frac{1}{4}$ & Qgd & 1283.09 & 2 & M & & & 6.10 & $10-63$ & 5.10 & $9-30$ & 6.50 & $4-6$ & \\
\hline $47 \mathrm{~N} 29 \mathrm{~W}$ & $2-1$ & $\mathrm{NE}$ & $\mathrm{SE}$ & Do. & 19 & $1 \frac{1}{4}$ & Qgd & 1531.32 & 2 & M & 3.93 & $4-63$ & 5.49 & $8-63$ & 3.44 & $5-13$ & 5.36 & $7-21$ & \\
\hline & $3-1$ & $\mathrm{NE}$ & $\mathrm{SW}$ & Bill Koski & 28 & 6 & Qgd & & 3 & M & 11.82 & $6-63$ & 13.78 & $5-63$ & 11.40 & $5-13$ & 16.06 & $8-28$ & \\
\hline & $34-1$ & $\mathrm{NW}$ & SW & Marquette Co. Rd. Comm. & 23 & $1 \frac{1}{4}$ & Qgd & & 3 & M & 3.08 & $5-63$ & 5.27 & $2-63$ & 2.67 & $5-14$ & 5.26 & $2-6$ & \\
\hline & $36-1$ & & SW & Do. & 19 & $1 \frac{1}{4}$ & Qgd & 1498.67 & 2 & M & 1.77 & $5-63$ & 5.52 & $11-63$ & 1.79 & $5-14$ & 3.44 & $7-22$ & \\
\hline $47 \mathrm{~N} 28 \mathrm{~W}$ & $1-1$ & NW & $\mathrm{SE}$ & $\begin{array}{l}\text { Inland Stee1 Co. } \\
\text { (Morris 非 1) }\end{array}$ & 216 & 38 & Qgd & & 4 & Q & 20.59 & $12-63$ & 70.99 & $10-61$ & 18.95 & $10-20$ & 21.08 & $2-19$ & $\begin{array}{l}\mathrm{P}, \text { recovery } \\
\text { Recorder re- } \\
\text { moved } 12-4-65\end{array}$ \\
\hline & $3-1$ & SW & $\mathrm{SW}$ & Ely Township & 75 & 8 & Qgd & & 4 & $\mathrm{R}$ & 13.60 & $8-61$ & 18.09 & $3-63$ & 14.69 & $10-3$ & $\underline{19.26}$ & 4-10 & \\
\hline & $8-1$ & $\mathrm{NW}$ & $\mathrm{NW}$ & Marquette Co. Rd. Comm. & 18 & $1 \frac{1}{4}$ & Qgd & 1542.22 & 2 & M & & & 3.02 & $11-63$ & 0.02 & $5-13$ & 2.62 & $2-6$ & \\
\hline & $10-1$ & NW & $\mathrm{NW}$ & Clarance Carlson & 17 & 6 & Qgd & & 4 & $\mathrm{~s}$ & 8.35 & $9-61$ & 14.06 & $2-62$ & 11.48 & $5-13$ & $\underline{14.92}$ & $1-10$ & $\begin{array}{l}\text { Record dis- } \\
\text { continued 6-64 }\end{array}$ \\
\hline & $15-1$ & $\mathrm{SW}$ & $\mathrm{NE}$ & Marquette Co. Rd. Conm. & 38 & $1 \frac{1}{4}$ & Qgd & 1523.81 & 2 & M & & & 18.40 & $11-10$ & 17.45 & $10-29$ & 19.16 & $5-14$ & \\
\hline & $28-1$ & NW & $\mathrm{SW}$ & Do. & 16 & $1 \frac{1}{4}$ & Qgd & 1484.79 & 2 & M & 1.75 & $5-28$ & 3.89 & $8-27$ & $\underline{1.16}$ & $5-14$ & 3.75 & $7-22$ & \\
\hline & $35-1$ & NW & SW & Do. & 52 & $1 \frac{1}{4}$ & Qgd & 1481.85 & 2 & M & & & 36.85 & $12-63$ & 37.86 & $6-18$ & 36.56 & $12-1$ & \\
\hline $47 \mathrm{~N} 26 \mathrm{~W}$ & $24-1$ & SW & $\mathrm{NE}$ & $\begin{array}{l}\text { Cleveland C1iffs Iron } \\
\text { Company }\end{array}$ & 33 & $1 \frac{1}{4}$ & Qgd & 1227.44 & 2 & M & 22.06 & $6-63$ & 23.54 & $4-63$ & 20.56 & $5-12$ & 25.25 & $10-28$ & \\
\hline & $25-1$ & $\mathrm{NE}$ & $\mathrm{NE}$ & MDC & 35 & $1 \frac{1}{4}$ & Qgd & 1222.39 & 2 & M & 17.44 & $6-63$ & 23.36 & $11-63$ & 16.93 & $5-12$ & 20.28 & $10-28$ & \\
\hline & $25-2$ & NW & $\mathrm{SW}$ & Do. & 26 & $1 \frac{1}{4}$ & Qgd & 1218.02 & 2 & M & & & 16.70 & $12-63$ & 13.85 & $6-17$ & 17.02 & 4-7 & \\
\hline & $25-3$ & NW & $\mathrm{SE}$ & Do. & 26 & $1 \frac{1}{4}$ & Qgd & 1219.42 & 1 & M & & & & & 6.17 & $5-12$ & 8.01 & $7-21$ & $\begin{array}{l}\text { Record } \\
\text { started 5-12 }\end{array}$ \\
\hline & $26-1$ & NW & $\mathrm{SE}$ & Do. & 35 & $1 \frac{1}{4}$ & Qgd & e1220 & 1 & $\mathrm{M}$ & & & & & 1.40 & $5-12$ & 5.21 & $7-21$ & Do. $\quad 5-12$ \\
\hline & $36-1$ & NW & $\mathrm{NW}$ & $\begin{array}{l}\text { Cleveland Cliffs Iron } \\
\text { Company }\end{array}$ & 28 & $1 \frac{1}{4}$ & Qgd & 1214.44 & 2 & M & & & 7.28 & $11-63$ & 5.18 & $5-12$ & 7.73 & $4-7$ & \\
\hline & $36-5$ & SE & SW & MDC & 29 & $1 \frac{1}{4}$ & Qgd & 1213.25 & 2 & M & & & 12.86 & $11-63$ & 11.08 & $5-12$ & 12.34 & $7-21$ & \\
\hline $47 \mathrm{~N} 25 \mathrm{~W}$ & $12-1$ & $\mathrm{NE}$ & SW & Marquette Co. Rd. Comm. & 35 & $1 \frac{1}{4}$ & Qgd & e695 & 2 & M & & & 4.60 & $10-63$ & 14.43 & $5-13$ & 14.74 & $2-11$ & \\
\hline & $15-1$ & SW & $\mathrm{SW}$ & Frank Bollero & 245 & 6 & Qgd & & 3 & M & 92.09 & $10-62$ & 99.09 & $6-62$ & 89.82 & $5-12$ & 96.64 & $7-21$ & \\
\hline & $19-1$ & SW & N SW & MDC & 86 & $1 \frac{1}{4}$ & Qgd & 1226.11 & 2 & M & & & 37.10 & $11-63$ & 31.59 & $5-12$ & 36.11 & $10-28$ & \\
\hline & $20-1$ & SW & N SW & Do. & 103 & $1 \frac{1}{4}$ & Qgd & 1244.00 & 2 & M & 87.36 & $5-63$ & 87.76 & $5-63$ & 89.12 & $9-23$ & $\underline{89.68}$ & $10-29$ & \\
\hline & $21-1$ & SW & SW & Do. & 161 & $1 \frac{1}{4}$ & Qgd & 1242.84 & 2 & M & 143.19 & $5-63$ & 144.99 & $5-63$ & 144.04 & $9-29$ & 146.12 & $9-3$ & \\
\hline & $27-1$ & SE & SW & Do. & 86 & $1 \frac{1}{4}$ & Qgd & e 1090 & 2 & M & & & 69.23 & $12-63$ & 70.06 & $5-5$ & 70.52 & $10-29$ & \\
\hline & $32-1$ & $\mathrm{NE}$ & Sw & Do. & 125 & $1 \frac{1}{4}$ & Qgd & 1243.17 & 2 & M & 96.85 & $5-63$ & 98.10 & $11-63$ & 98.10 & $9-29$ & 110.02 & $10-28$ & \\
\hline $47 \mathrm{~N} 24 \mathrm{~W}$ & $18-1$ & SE & SW & Charles Shirtz & 75 & 2 & Qgd & 703 & 2 & M & & & 36.23 & $11-63$ & 35.92 & $5-12$ & 37.56 & $4-6$ & \\
\hline & $28-1$ & SW & N SW & Marquette Co. Rd. Comm. & 91 & $1 \frac{1}{4}$ & Qgd & 709 & 2 & M & & & 25.18 & $11-30$ & 25.34 & $6-17$ & 25.52 & $9-29$ & \\
\hline $46 \mathrm{~N} 29 \mathrm{~W}$ & $18-2$ & $\mathrm{NE}$ & SW & Republic Township & 39 & $1 \frac{1}{4}$ & Qgd & & 3 & $\mathrm{~s}$ & 11.36 & $5-62$ & 14.38 & $8-63$ & 13.72 & $4-7$ & 14.02 & $1-10$ & $\begin{array}{l}\text { Record dis- } \\
\text { continued 6- } \\
64\end{array}$ \\
\hline & $22-1$ & NW & $\mathrm{N} N$ & Marquette Co. Rd. Comm. & 35 & $1 \frac{1}{4}$ & Qgd & 1507.79 & 2 & M & 11.20 & $6-63$ & 11.87 & $11-63$ & 11.27 & $5-12$ & $\underline{12.10}$ & $2-6$ & \\
\hline & $36-1$ & SW & N NE & Do. & 30 & $1 \frac{1}{4}$ & Qgd & 1484.22 & 2 & M & 9.36 & $2-63$ & 10.87 & $1-63$ & 9.72 & $8-28$ & $\underline{12.20}$ & $2-6$ & \\
\hline $46 \mathrm{~N} \mathrm{28W}$ & $1-1$ & SE & $\mathrm{NW}$ & Clarance Carlson & 96 & 6 & Qgd & & 4 & M & 35.59 & $8-61$ & 41.96 & $7-63$ & 42.57 & $10-6$ & 42.81 & $6-18$ & \\
\hline & $8-1$ & SW & NE & Marquet te Co. Rd. Comm. & 23 & $1 \frac{1}{4}$ & Qgd & 1463.63 & 2 & M & 6.01 & $6-63$ & 9.44 & $11-63$ & 5.30 & $5-14$ & 7.85 & $7-21$ & \\
\hline & $12-3$ & NW & N SW & Mrs. S. L. Hill & 19 & $1 \frac{1}{4}$ & Qgd & & 3 & M & 2.21 & $3-63$ & 3.04 & $8-63$ & 2.00 & $10-6$ & 2.89 & $7-21$ & \\
\hline
\end{tabular}




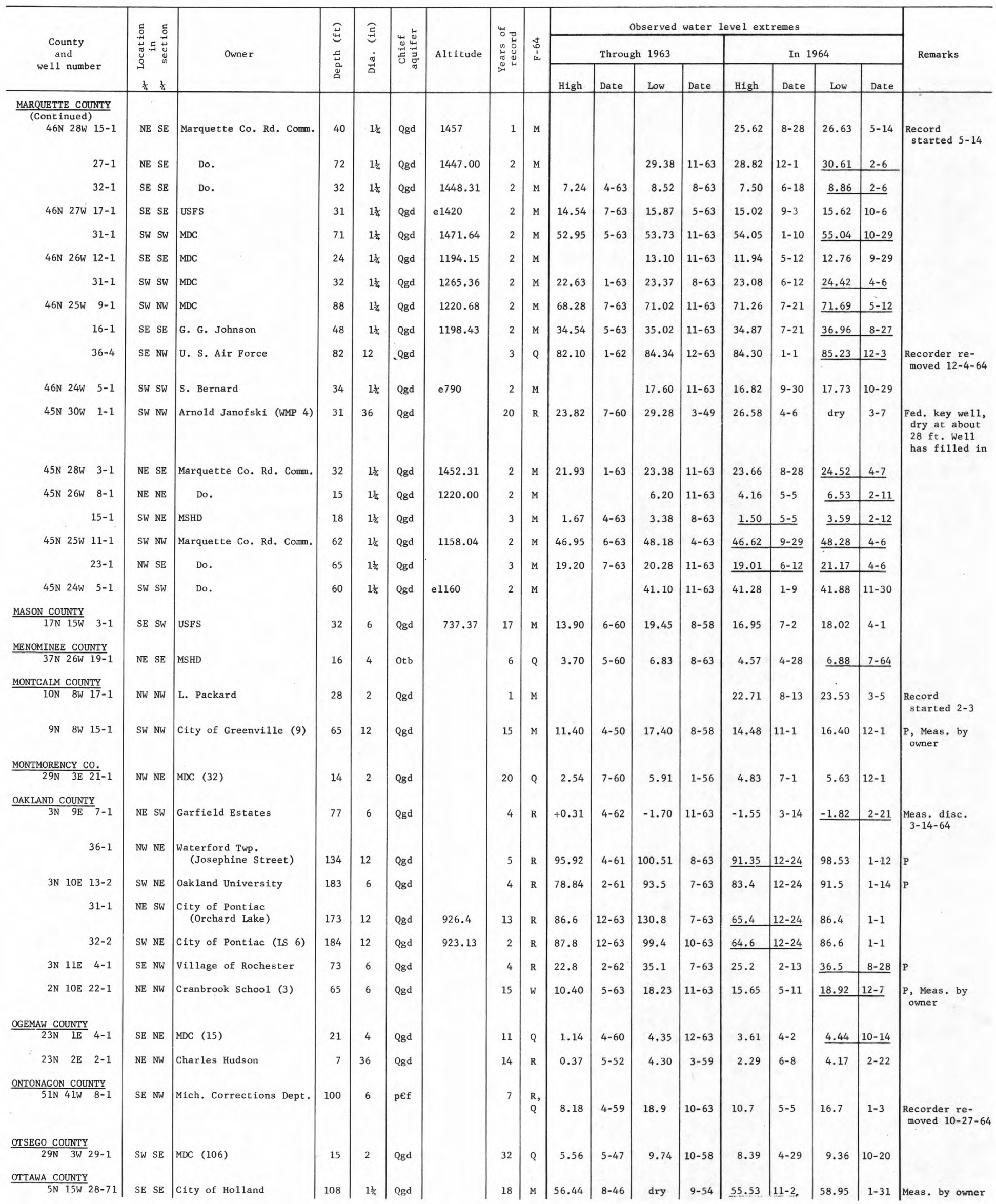




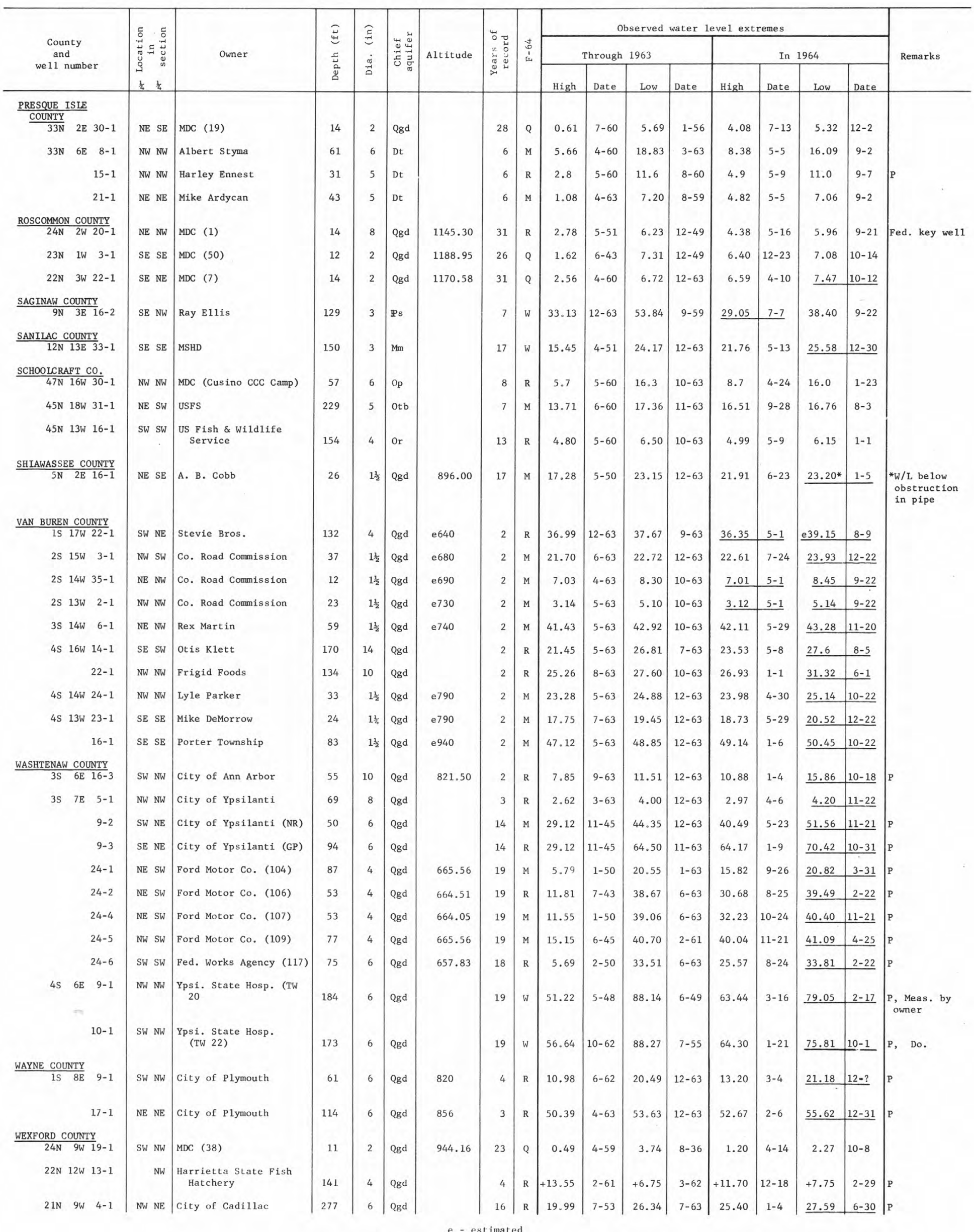




\begin{tabular}{|c|c|c|c|c|c|c|c|c|c|c|c|c|c|c|c|}
\hline Water User & Jan. & Feb. & Mar. & Apr. & May & June & July & Aug. & Sept. & oct. & Nov. & Dec. & $\begin{array}{l}1964 \\
\text { Total }\end{array}$ & $\begin{array}{l}\text { Max. } \\
\text { Day }\end{array}$ & $\begin{array}{l}\text { Min. } \\
\text { Day }\end{array}$ \\
\hline $\begin{array}{l}\text { ALCONA COUNTY } \\
\text { City of Harrisuille }\end{array}$ & 1.15 & 1.12 & 1.03 & 0.79 & 1.00 & 1.75 & 2.08 & 1.69 & 1.17 & 0.88 & 0.83 & 0.99 & 14.48 & 0.11 & 0.02 \\
\hline $\begin{array}{l}\text { ALGER COUNTY } \\
\text { Burt Township }\end{array}$ & 1.67 & 1.42 & 1.51 & 1.62 & 1.71 & 1.84 & 2.15 & 2.14 & 1.95 & 1.54 & 1.37 & 1.53 & 20.45 & 0.85 & 0.29 \\
\hline ALLEGAN COUNTY & & & & & & & & & & & & & & & \\
\hline City of Allegan & 24.6 & 22.2 & 23.1 & 26.8 & 24.8 & 34.2 & 35.2 & 47.6 & 27.8 & 26.9 & 23.8 & 22.0 & 339.0 & 2.35 & 0.53 \\
\hline City of Plainwell & 9.1 & 8.3 & 9.3 & 10.2 & 13.6 & 17.1 & 18.7 & 19.1 & 12.5 & 10.1 & 10.3 & 11.4 & 149.7 & 0.94 & 0.18 \\
\hline City of Otsego & 16.2 & 13.8 & 14.4 & 15.3 & 18.6 & 27.0 & 28.4 & 23.8 & 17.6 & 15.7 & 14.1 & 14.3 & 219.2 & 1.02 & $0.29^{\circ}$ \\
\hline $\begin{array}{l}\text { ANTRIM COUNTY } \\
\text { Village of Mancelona }\end{array}$ & 12.8 & 12.2 & 13.2 & 13.1 & 13.2 & 15.3 & 15.0 & 14.8 & 14.0 & 13.9 & 12.6 & 12.5 & 162.6 & & \\
\hline BARRY COUNTY & & & & & & & & & & & & & & & \\
\hline $\begin{array}{l}\text { City of Hastings } \\
\text { Village of Middleville }\end{array}$ & $\begin{array}{r}32.3 \\
7.7\end{array}$ & $\begin{array}{r}30.2 \\
7.9\end{array}$ & $\begin{array}{r}33.1 \\
8.0\end{array}$ & $\begin{array}{r}33.5 \\
8.3\end{array}$ & $\begin{array}{r}38.7 \\
8.6\end{array}$ & $\begin{array}{l}47.9 \\
10.7\end{array}$ & $\begin{array}{l}50.3 \\
11.0\end{array}$ & $\begin{array}{l}46.3 \\
11.3\end{array}$ & $\begin{array}{l}40.4 \\
10.3\end{array}$ & $\begin{array}{r}40.4 \\
9.8\end{array}$ & $\begin{array}{r}37.5 \\
7.6\end{array}$ & $\begin{array}{r}34.3 \\
7.9\end{array}$ & $\begin{array}{l}464.9 \\
109.1\end{array}$ & $\begin{array}{l}2.56 \\
0.66\end{array}$ & $\begin{array}{l}0.62 \\
0.09\end{array}$ \\
\hline $\begin{array}{l}\text { BAY COUNTY } \\
\text { a) City of Pinconning }\end{array}$ & 1.23 & 0.73 & 0.46 & & & & & 0.17 & 0.24 & & 0.10 & 0.22 & 3.15 & - & \\
\hline $\begin{array}{l}\text { BENZIE COUNTY } \\
\text { City of Frankfort }\end{array}$ & 5.5 & 5.3 & 4.3 & 4.6 & 5.4 & 10.4 & 10.1 & 8.6 & 6.4 & 5.3 & 5.3 & 5.2 & 76.4 & 0.50 & 0.15 \\
\hline BERRIEN COUNTY & & & & & & & & & & & & & & & \\
\hline Village of Berrien Springs & 8.8 & 8.4 & 9.2 & 9.0 & 10.9 & 11.4 & 11.5 & 11.9 & 11.2 & 11.0 & 10.8 & 8.9 & 123.0 & 0.53 & 0.24 \\
\hline $\begin{array}{l}\text { City of Buchanan } \\
\text { e) City of Coloma }\end{array}$ & $\begin{array}{l}53.2 \\
4.67\end{array}$ & $\begin{array}{l}47.3 \\
4.18\end{array}$ & $\begin{array}{l}52.9 \\
4.68\end{array}$ & $\begin{array}{l}52.3 \\
4.90\end{array}$ & $\begin{array}{l}59.5 \\
5.18\end{array}$ & $\begin{array}{c}71.2 \\
5.36\end{array}$ & $\begin{array}{c}69.9 \\
5.68\end{array}$ & $\begin{array}{c}68.5 \\
5.85\end{array}$ & $\begin{array}{l}59.6 \\
5.52\end{array}$ & $\begin{array}{l}57.7 \\
5.17\end{array}$ & $\begin{array}{l}56.9 \\
4.68\end{array}$ & $\begin{array}{l}58.2 \\
5.18\end{array}$ & $\begin{array}{c}707.2 \\
61.05\end{array}$ & 3.21 & 0.85 \\
\hline City of Niles & & & & & 107 & 119 & 110 & 119 & 99 & 93 & 84 & 87 & 1163 & 5.73 & 1.62 \\
\hline BRANCH COUNTY & & & & & & & & & & & & & & & \\
\hline City of Bronson & 20.0 & 20.2 & 20.2 & 23.1 & 22.2 & 24.0 & 25.0 & 26.8 & 25.5 & 25.6 & 20.7 & 21.6 & 274.9 & 1.39 & 0.88 \\
\hline $\begin{array}{l}\text { City of Coldwater } \\
\text { State Home and Training }\end{array}$ & 59.9 & 54.2 & 60.5 & 62.7 & 78.8 & 99.2 & 111.7 & 96.3 & 81.6 & 76.9 & 70.7 & 65.0 & 917.5 & 5.37 & 1.11 \\
\hline School at Coldwater & 12.7 & 12.4 & 13.3 & 12.8 & 14.1 & 13.8 & 15.8 & 15.3 & 13.9 & 13.9 & 14.2 & 13.3 & 165.5 & $\mathrm{NA}$ & NA \\
\hline $\begin{array}{l}\text { CALHOUN COUNTY } \\
\text { City of Albion } \\
\text { American Legion Hospital }\end{array}$ & 165 & 151 & 164 & 161 & 176 & 182 & 180 & 186 & 178 & 186 & 172 & 161 & 2062 & 7.73 & \\
\hline at Battle Creek & 1.05 & 0.74 & 0.92 & 1.23 & 0.90 & 0.85 & 1.08 & 1.18 & 0.80 & 0.86 & 1.04 & 1.04 & 11.69 & 0.04 & 0.02 \\
\hline Village of Athens & 2.59 & 0.46 & 2.13 & 3.02 & 3.08 & 5.10 & 6.37 & 4.75 & 5.04 & 6.25 & 4.98 & 2.80 & 46.57 & 0.23 & 0.13 \\
\hline City of Battle Creek & 275 & 246 & 274 & 307 & 408 & 452 & 388 & 380 & 335 & 309 & 279 & 269 & 3922 & 21.10 & 6.12 \\
\hline Battle Creek Township & 20.6 & 19.2 & 20.2 & 23.2 & 37.1 & 52.1 & 51.5 & 45.4 & 24.5 & 27.7 & 27.2 & 26.0 & 374.7 & 3.06 & 0.42 \\
\hline City of Marshall & 30.1 & 25.9 & 27.3 & 28.1 & 37.7 & 43.5 & 48.0 & 46.0 & 34.4 & 31.3 & 29.5 & 29.0 & 410.8 & 2.26 & 0.67 \\
\hline CASS COUNTY & & & & & & & & & & & & & & & \\
\hline $\begin{array}{l}\text { City of Dowagiac } \\
\text { Village of Marcellus }\end{array}$ & $\begin{aligned} & 22.0 \\
& 1.60\end{aligned}$ & $\begin{array}{c}18.8 \\
1.46\end{array}$ & $\begin{array}{l}21.1 \\
1.22\end{array}$ & $\begin{array}{r}23.6 \\
1.84\end{array}$ & 22.4 & 33.1 & 26.8 & 18.7 & 32.9 & 28.4 & 25.5 & 23.0 & 296.3 & 0.39 & 0 \\
\hline & & & & & & & 5.04 & & 2.20 & 1.00 & 1.00 & 1.03 & 23.07 & (3) & 0.00 \\
\hline City of East Jordan & 9.7 & 9.8 & 9.6 & 9.4 & 13.4 & 18.6 & 23.3 & 19.4 & 16.0 & 17.4 & 15.1 & 15.8 & 177.5 & & \\
\hline CHEBOYGAN COUNTY & & & & & & & & & & & & & & & \\
\hline City of Cheboygan & 12.9 & 15.9 & 18.0 & 16.7 & 17.7 & 19.6 & 22.1 & 24.7 & 16.6 & 16.7 & 16.8 & 11.8 & 209.5 & 0.83 & 0.24 \\
\hline Village of Mackinac City & 3.95 & 5.51 & 5.75 & 5.54 & 5.07 & 5.64 & 7.59 & 7.57 & 5.30 & 3.49 & 2.60 & 1.96 & 59.97 & 0.30 & 0.03 \\
\hline $\begin{array}{l}\text { CHIPPEWA COUNTY } \\
\text { Kincheloe Air Force Base } \\
\text { near Kinross }\end{array}$ & 19.1 & 17.1 & 17.6 & 18.5 & 28.0 & 32.4 & 38.4 & 29.1 & 25.0 & 24.7 & 22.5 & 23.7 & 296.1 & 1.70 & 0.37 \\
\hline CLARE COUNTY & & & & & & & & & & & & & & & \\
\hline City of Clare & 11.9 & 22.0 & 17.6 & 18.6 & 23.5 & 33.8 & 32.9 & 22.9 & 19.0 & 17.9 & 17.8 & 20.1 & 258.0 & 1.68 & 0.45 \\
\hline City of Harrison & 2.39 & 2.32 & 3.19 & 1.01 & 2.84 & 5.95 & 3.62 & 2.92 & 2.28 & 2.55 & 1.91 & 2.16 & 33.14 & 0.30 & 0.05 \\
\hline $\begin{array}{l}\text { CLINTON COUNTY } \\
\text { Village of E1sie }\end{array}$ & & & & & & & & & & & & & $\mathrm{e} 36.0$ & & \\
\hline Village of Ovid & 1.81 & 1.81 & 1.93 & 2.04 & 2.44 & 2.26 & 4.81 & 2.35 & 2.36 & 1.95 & 1.60 & 1.81 & 27.17 & 0.16 & 0.04 \\
\hline City of St. Johns & 30.0 & 29.5 & 30.8 & 31.2 & 33.2 & 36.9 & 38.1 & 38.1 & 36.5 & 36.9 & 33.3 & 34.4 & 408.9 & 1.57 & 0.47 \\
\hline CRAWFORD COUNTY & & & & & & & & & & & & & & & \\
\hline City of Grayling & 5.7 & 5.6 & 5.8 & 5.6 & 7.6 & 10.8 & 16.4 & 6.6 & 7.6 & 6.0 & 5.6 & 6.3 & 89.6 & 0.96 & 0.08 \\
\hline EATON COUNTY & & & & & & & & & & & & & & & \\
\hline $\begin{array}{l}\text { e) Village of Bellevue } \\
\text { City of olivet }\end{array}$ & 2.00 & 2.00 & 2.00 & 2.00 & 2.00 & 2.10 & 2.50 & 2.50 & 2.00 & 2.00 & 2.00 & 2.00 & $\begin{array}{rl} & 25.10 \\
\mathrm{e} & 33.6\end{array}$ & & \\
\hline City of Charlotte & 34.9 & 32.9 & 34.3 & 31.3 & 38.3 & 43.7 & 45.1 & 46.8 & 39.6 & 41.4 & 39.6 & 40.9 & 468.8 & 2.12 & 0.60 \\
\hline City of Eaton Rapids & 26.5 & 23.3 & 24.4 & 22.9 & 25.5 & 26.3 & 28.5 & 31.3 & 25.3 & 23.7 & 21.3 & 21.1 & 300.1 & & \\
\hline City of Grand Ledge & 12.9 & 10.3 & 12.2 & 11.9 & 14.2 & 16.3 & 17.0 & 16.0 & 13.7 & 13.0 & 11.7 & 11.7 & 160.9 & 0.94 & 0.19 \\
\hline Oldsmobile Parts Whse. & 1.38 & 1.90 & 1.52 & 1.28 & 0.85 & 1.05 & 1.58 & 1.68 & 1.70 & 0.98 & 2.15 & 1.25 & 17.32 & & \\
\hline EMMET COUNTY & & & & & & & & & & & & & & & \\
\hline City of Harbor Springs & 7.1 & 7.3 & 6.6 & 6.5 & 9.5 & 16.6 & 23.9 & 28.1 & 14.6 & 7.4 & 7.3 & 6.1 & 141.0 & 1.64 & 0.19 \\
\hline $\begin{array}{l}\text { GENESEE COUNTY } \\
\text { Beecher Metropolitan }\end{array}$ & & & & & & & & & & & & & & & \\
\hline $\begin{array}{l}\text { District } \\
\text { Village of Clio }\end{array}$ & 25.3 & 24.8 & 26.6 & 25.5 & 31.0 & 34.6 & 36.4 & 31.6 & 29.0 & 29.1 & 26.5 & 31.3 & $\begin{array}{l}351.7 \\
\mathrm{e} 51.0\end{array}$ & $\begin{array}{l}1.75 \\
0.20\end{array}$ & $\begin{array}{l}0.67 \\
0.13\end{array}$ \\
\hline City of Davison & 9.8 & 9.3 & 10.1 & 10.4 & 11.7 & 14.1 & 15.8 & 13.7 & 11.3 & 11.5 & 10.4 & 10.8 & 138.9 & 0.80 & 0.19 \\
\hline City of Fenton & 16.8 & 15.6 & 15.2 & 16.6 & 19.9 & 21.5 & 25.6 & 21.1 & 19.6 & 18.5 & 16.6 & 17.9 & 224.9 & 1.17 & 0.24 \\
\hline $\begin{array}{l}\text { Fisher Body Div, at } \\
\text { Grand Blanc }\end{array}$ & 7.01 & 6.21 & 6.98 & 7.31 & 8.00 & 7.33 & 7.01 & 7.08 & 7.22 & 3.70 & 6.94 & 6.51 & 81.30 & & \\
\hline village of Flushing & 6.84 & 6.23 & 6.84 & 6.69 & 7.23 & 8.05 & 7.30 & 6.48 & 6.79 & 7.26 & $\mathrm{f}$ & $\dot{\mathrm{f}}$ & $\begin{array}{l}81.30 \\
69.71\end{array}$ & & \\
\hline Village of Linden & 2.86 & 2.63 & 2.65 & 4.00 & 5.89 & 6.00 & 7.99 & 5.43 & 5.11 & 4.66 & 3.36 & 3.42 & 54.00 & 0.30 & 0.11 \\
\hline City of Mt. Morris & 6.05 & 5.59 & 6.21 & 6.15 & 7.18 & 7.51 & 8.11 & 7.28 & 7.19 & 6.98 & 6.03 & 5.71 & 79.99 & 0.36 & 0.15 \\
\hline Village of Otisville & 1.21 & 1.06 & 1.07 & 1.06 & 1.13 & 1.25 & 1.19 & 1.24 & 1.22 & 1.16 & 1.02 & 1.09 & 13.70 & 0.05 & 0.03 \\
\hline
\end{tabular}


Table 3.--Reported ground-water pumpage by some Michigan municipalities, institutions, grou

\begin{tabular}{|c|c|c|c|c|c|c|c|c|c|c|c|c|c|c|c|}
\hline Water User & Jan. & Feb. & Mar. & Apr. & May & June & July & Aug. & Sept. & Oct. & Nov. & Dec. & $\begin{array}{l}1964 \\
\text { Total }\end{array}$ & $\begin{array}{l}\text { Max. } \\
\text { Day }\end{array}$ & $\begin{array}{l}\text { Min. } \\
\text { Day }\end{array}$ \\
\hline $\begin{array}{l}\text { GLADWIN COUNTY } \\
\text { City of Beaverton }\end{array}$ & 2.62 & 2.18 & 2.16 & 2.91 & 2.89 & 2.57 & 1.02 & 4.51 & 1.61 & 1.78 & 2.16 & 3.02 & 29.43 & & \\
\hline GOGEBIC COUNTY & & & & & & & & & & & & & & & \\
\hline $\begin{array}{l}\text { City of Bessemer } \\
\text { City of Ironwood }\end{array}$ & $\begin{array}{l}10.6 \\
24.9\end{array}$ & $\begin{array}{l}10.5 \\
22.9\end{array}$ & $\begin{array}{l}10.6 \\
24.1\end{array}$ & $\begin{array}{l}10.1 \\
24.5\end{array}$ & $\begin{array}{l}10.7 \\
25.4\end{array}$ & $\begin{array}{l}10.5 \\
26.8\end{array}$ & $\begin{array}{l}11.7 \\
30.3\end{array}$ & $\begin{array}{l}10.5 \\
29.1\end{array}$ & $\begin{array}{l}10.2 \\
27.0\end{array}$ & $\begin{array}{r}9.7 \\
26.6\end{array}$ & $\begin{array}{r}9.1 \\
25.2\end{array}$ & $\begin{array}{r}9.7 \\
29.1\end{array}$ & $\begin{array}{l}123.9 \\
31.5 .9\end{array}$ & $\begin{array}{l}0.47 \\
1.13\end{array}$ & $\begin{array}{l}0.16 \\
0.39\end{array}$ \\
\hline City of Wakefield & 7.58 & 5.96 & 6.75 & 6.38 & 6.37 & 6.51 & 7.44 & 6.97 & 6.65 & 6.30 & 6.36 & 6.81 & 80.08 & & \\
\hline GRATIOT COUNTY & & & & & & & & & & & & & & & \\
\hline City of Alma & 44.6 & 41.6 & 47.8 & 52.1 & 55.5 & 61.5 & $\begin{array}{c}60.5 \\
3.70\end{array}$ & $\begin{array}{c}61.5 \\
3.00\end{array}$ & $\begin{array}{l}60.0 \\
2.80\end{array}$ & $\begin{array}{l}60.5 \\
2.70\end{array}$ & $\begin{array}{l}58.7 \\
2.50\end{array}$ & $\begin{array}{l}52.2 \\
2.60\end{array}$ & $\begin{array}{l}656.5 \\
34.78\end{array}$ & $\begin{array}{l}2.74 \\
0.16\end{array}$ & $\begin{array}{l}0.89 \\
0.07\end{array}$ \\
\hline $\begin{array}{l}\text { Village of Breckenridge } \\
\text { City of Ithaca }\end{array}$ & $\begin{array}{l}2.80 \\
5.91\end{array}$ & $\begin{array}{l}2.60 \\
5.31\end{array}$ & $\begin{array}{l}2.90 \\
5.06\end{array}$ & $\begin{array}{l}2.60 \\
5.32\end{array}$ & $\begin{array}{l}3.11 \\
5.45\end{array}$ & $\begin{array}{l}3.47 \\
6.26\end{array}$ & $\begin{array}{l}3.70 \\
6.75\end{array}$ & $\begin{array}{l}3.00 \\
5.57\end{array}$ & $\begin{array}{l}2.80 \\
4.63\end{array}$ & 3.91 & 4.99 & 3.86 & 63.02 & 0.35 & $\begin{array}{l}0.01 \\
0.14\end{array}$ \\
\hline City of St. Louis & 19.6 & 18.7 & 20.9 & 19.8 & 21.1 & 22.9 & 22.1 & 22.1 & 19.9 & 21.7 & 22.9 & 24.4 & 256.1 & 1.21 & 0.47 \\
\hline HILLSDALE COUNTY & & & & & & & & & & & & & & & \\
\hline $\begin{array}{l}\text { Village of Jonesville } \\
\text { b) City of Hillsdale }\end{array}$ & 7.7 & 6.8 & 8.4 & 9.1 & 9.5 & $\begin{array}{l}10.8 \\
28.0\end{array}$ & $\begin{array}{l}10.9 \\
34.3\end{array}$ & $\begin{array}{r}9.6 \\
35.5\end{array}$ & $\begin{array}{r}8.5 \\
18.8\end{array}$ & 9.5 & 8.2 & 7.1 & $\begin{array}{l}106.1 \\
116.6\end{array}$ & $\begin{array}{l}0.55 \\
1.94\end{array}$ & $\begin{array}{l}0.20 \\
0.74\end{array}$ \\
\hline HOUGHTON COUNTY & & & & & & & & & & & & & & & \\
\hline City of Hancock & 13.6 & 12.6 & 12.3 & 14.6 & 14.1 & $\begin{array}{l}14.1 \\
23.6\end{array}$ & $\begin{array}{l}14.3 \\
31.4\end{array}$ & $\begin{array}{l}17.1 \\
24.7\end{array}$ & $\begin{array}{l}16.2 \\
24.9\end{array}$ & $\begin{array}{l}14.2 \\
25.2\end{array}$ & $\begin{array}{l}15.2 \\
23.9\end{array}$ & $\begin{array}{l}13.5 \\
22.3\end{array}$ & $\begin{array}{l}171.8 \\
304.8\end{array}$ & $\begin{array}{l}0.80 \\
1.25\end{array}$ & $\begin{array}{l}0.34 \\
0.56\end{array}$ \\
\hline $\begin{array}{l}\text { City of Houghton } \\
\text { Chassell Township }\end{array}$ & $\begin{array}{l}27.0 \\
40\end{array}$ & $\begin{array}{l}25.5 \\
64\end{array}$ & $\begin{array}{l}26.0 \\
35\end{array}$ & $\begin{array}{l}24.5 \\
35\end{array}$ & $\begin{array}{l}25.8 \\
75\end{array}$ & $\begin{array}{l}23.6 \\
128\end{array}$ & $\begin{array}{l}31.4 \\
185\end{array}$ & 140 & $\begin{array}{l}24.9 \\
97\end{array}$ & 91 & 77 & 130 & 1097 & 9.29 & 7.90 \\
\hline HURON COUNTY & & & & & & & & & & & & & & & \\
\hline $\begin{array}{l}\text { Village of Pigeon } \\
\text { Village of Sebewaing }\end{array}$ & 3.52 & 3.18 & 3.52 & 3.89 & 4.02 & 4.54 & 6.70 & 6.86 & 4.86 & 5.02 & 3.89 & 4.19 & 54.19 & 0.22 & 0.11 \\
\hline Village of Sebewaing & 11.2 & 10.1 & 7.6 & 9.6 & 8.4 & 13.3 & 12.7 & 11.4 & 11.6 & 10.6 & 9.7 & 7.2 & 123.4 & & \\
\hline $\begin{array}{l}\text { INGHAM COUNTY } \\
\text { City of East Lansing }\end{array}$ & & & & & & & & & & & & & & & \\
\hline $\begin{array}{l}\text { City of East Lansing } \\
\text { City of Lansing }\end{array}$ & 52.3 & 53.9 & 54.1 & 57.7 & 71.3 & 83.9 & 86.1 & 74.6 & 61.5 & 66.8 & 61.5 & 56.9 & 780.6 & 3.96 & \\
\hline & & & & $\begin{array}{r}583 \\
43.9\end{array}$ & & & $\begin{array}{l}711 \\
43.7\end{array}$ & $\begin{array}{l}627 \\
40.1\end{array}$ & $\begin{array}{l}602 \\
47.2\end{array}$ & $\begin{array}{l}516 \\
29.0\end{array}$ & $\begin{array}{l}570 \\
40.6\end{array}$ & $\begin{array}{l}586 \\
40.5\end{array}$ & $\begin{array}{r}7247 \\
526.9\end{array}$ & 40.99 & \\
\hline Village of Leslie & 5.30 & 3.95 & 4.16 & 4.51 & 5.83 & 7.30 & 8.13 & 8.07 & $\quad 5.14$ & 5.11 & 4.84 & 5.29 & 67.63 & 0.11 & 0.48 \\
\hline City of Mason & 10.9 & 11.6 & 11.7 & 11.7 & 17.3 & 20.7 & 19.3 & 16.4 & 13.6 & 13.0 & 11.9 & 11.2 & 169.3 & & \\
\hline Meridian Township & 2.96 & 2.51 & 2.64 & 2.75 & 3.68 & 5.20 & 5.44 & 4.21 & $\quad 3.07$ & 3.03 & 2.85 & 3.16 & 41.50 & & \\
\hline $\begin{array}{l}\text { Michigan State University } \\
\text { at East Lansing }\end{array}$ & 103 & 99 & 110 & 103 & 116 & 101 & 102 & 90 & 86 & 117 & 116 & 112 & 1255 & 4.89 & 1.75 \\
\hline $\begin{array}{l}\text { Oldsmobile Forge Plant } \#_{2} \\
\text { Oldsmobile Main Plant } 1 \text { 1 }\end{array}$ & 14.1 & 14.8 & 7.6 & 12.4 & 13.8 & 17.9 & 13.8 & 16.2 & 15.1 & 12.4 & 13.4 & 13.1 & 164.6 & & \\
\hline at Lansing & $\mathrm{NA}$ & $\mathrm{NA}$ & $\mathrm{NA}$ & $\mathrm{NA}$ & NA & $\mathrm{NA}$ & 11.4 & 6.2 & 5.6 & 0.5 & 0.7 & 0.9 & 25.30 & & \\
\hline IONIA COUNTY & & & & & & & & & & & & & & & \\
\hline City of Ionia & 28.6 & 25.7 & 28.9 & 29.9 & 36.0 & 41.8 & 35.7 & 36.0 & 31.7 & 25.1 & 25.8 & 28.1 & 373.3 & 1.70 & 0.48 \\
\hline $\begin{array}{l}\text { State Hospital at Ionia } \\
\text { Michigan Reformatory at }\end{array}$ & 9.7 & 8.8 & 9.0 & 8.8 & 9.3 & 10.1 & 10.3 & 9.7 & 8.9 & 8.9 & 8.3 & 8.9 & 110.7 & 0.38 & 0.25 \\
\hline $\begin{array}{l}\text { Michigan Reformatory at } \\
\text { Ionia } \\
\text { Michigan Training Unit }\end{array}$ & 16.7 & 15.4 & 14.4 & 17.2 & 16.9 & 22.7 & 20.2 & 23.8 & 19.2 & 17.6 & 17.2 & 17.3 & 218.6 & 0.89 & 0.50 \\
\hline at Ionia & 1.70 & 1.60 & 1.65 & 2.71 & 1.88 & 4.77 & 5.06 & 5.36 & 4.59 & 1.85 & 1.80 & 2.30 & 35.27 & 0.26 & 0.04 \\
\hline City of Portland & 9.3 & 8.9 & 10.1 & 10.6 & 12.8 & 15.6 & 15.2 & 12.4 & 11.5 & 10.3 & 9.3 & 8.9 & 134.9 & 0.52 & 0.29 \\
\hline Village of Saranac & 9.61 & 7.18 & 7.47 & 7.63 & 8.00 & 8.54 & 8.94 & 7.98 & 7.46 & 6.75 & 7.19 & 7.67 & 94.42 & 0.49 & .09 \\
\hline IOSCO COUNTY & & & & & & & & & & & & & & & \\
\hline Wurtsmith Air Force Base & 23.5 & 20.5 & 21.9 & 24.9 & 38.7 & 42.9 & 42.0 & 43.0 & 39.5 & 35.6 & 31.5 & 27.0 & 391.0 & 1.58 & 0.41 \\
\hline IRON COUNTY & & & & & & & & & & & & & & & \\
\hline City of Caspian & 8.11 & 7.28 & 8.26 & 8.14 & 8.57 & 5.98 & 8.14 & 6.42 & 7.92 & 8.83 & 4.43 & 6.83 & 88.91 & 0.52 & 0.22 \\
\hline City of Crystal Falls & 13.3 & 12.6 & 13.3 & 13.4 & 14.2 & 15.5 & 18.6 & 15.1 & 13.1 & 13.6 & 12.5 & 12.8 & 168.0 & 0.83 & 0.38 \\
\hline City of Iron River & 12.5 & 13.2 & 14.1 & 12.6 & 13.1 & 12.8 & 14.8 & 12.2 & 10.9 & 11.2 & 11.1 & 12.4 & 150.9 & 0.78 & 0.16 \\
\hline City of Stambaugh & 5.03 & 4.89 & 5.17 & 5.05 & 5.68 & 5.87 & 5.51 & 5.24 & 4.81 & 5.08 & 4.85 & 5.47 & 62.65 & 0.25 & 0.10 \\
\hline Stambaugh Township & 1.81 & 1.75 & 1.82 & 2.09 & 2.04 & 2.35 & 3.67 & 2.52 & 1.51 & 1.46 & 1.37 & 1.60 & 23.99 & & \\
\hline ISABELLA COUNTY & & & & & & & & & & & & & & & \\
\hline g) City of Mt. Pleasant & 48.7 & 50.2 & 46.9 & 52.0 & 53.9 & 70.2 & 61.9 & 48.4 & 53.1 & 57.2 & 52.4 & 50.5 & 645.4 & 3.93 & 0.94 \\
\hline Village of Shepherd & 1.94 & 1.77 & 2.17 & 2.17 & 1.99 & 2.30 & 2.23 & 2.18 & 2.65 & 2.27 & 2.42 & 2.66 & 26.75 & 0.13 & 0.04 \\
\hline JACKSON COUNTY & & & & & & & & & & & & & & & \\
\hline Village of Concord & 1.67 & 1.67 & 1.89 & 1.96 & 2.21 & 2.28 & 2.81 & 2.74 & 2.34 & 2.12 & 1.96 & 1.77 & 25.42 & 0.14 & 0.05 \\
\hline e) Village of Grass Lake & 1.90 & 1.80 & 1.60 & 1.60 & 1.90 & 2.00 & 2.80 & 2.90 & 2.80 & 2.40 & 2.00 & 2.00 & 25.70 & & \\
\hline $\begin{array}{l}\text { City of Jackson } \\
\text { State Prison of S. Mich. }\end{array}$ & 336 & 307 & 330 & 338 & 403 & 443 & 444 & 443 & 396 & 390 & 330 & 347 & 4507 & 21.76 & 5.61 \\
\hline at Jackson & 38.1 & 35.2 & 41.7 & 39.1 & 51.9 & 55.7 & 57.2 & 62.3 & 45.8 & 50.1 & 37.6 & 39.8 & 554.5 & 2.43 & 1.02 \\
\hline KALAMAZOO COUNTY & & & & & & & & & & & & & & & \\
\hline Village of Augusta & 1.53 & 1.53 & 1.73 & 1.89 & 1.74 & 1.04 & 1.90 & 3.52 & 1.81 & 1.86 & 1.82 & 1.56 & 21.93 & 0.14 & 0.09 \\
\hline City of Kalamazoo & 357 & 333 & 349 & 381 & 484 & 627 & 677 & 567 & 459 & 411 & 369 & 361 & 5375 & 29.64 & 3.60 \\
\hline $\begin{array}{l}\text { State Hospital at } \\
\text { Kalamazoo }\end{array}$ & 17.7 & 16.6 & 18.3 & 16.7 & 17.5 & 16.8 & 20.9 & 17.4 & 19.1 & 19.2 & 18.9 & 17.5 & 216.6 & 0.65 & 0.51 \\
\hline (ity of Portage & 9.6 & 9.7 & 8.6 & 11.6 & 20.7 & 31.8 & 28.8 & 22.8 & 15.8 & 13.7 & 12.1 & 12.3 & 197.5 & & \\
\hline Village of Vicksburg & 10.1 & 9.1 & 10.9 & 11.2 & 13.0 & 17.2 & 15.8 & 14.2 & 13.2 & 12.0 & 11.1 & 10.1 & 147.9 & 0.58 & 0.28 \\
\hline $\begin{array}{l}\text { Up john Co. near Kalamazoo } \\
\text { KVP-Sutherland Paper Co. }\end{array}$ & 256 & 261 & 266 & 285 & 308 & 343 & 355 & 336 & 317 & 312 & 280 & 260 & 3579 & 14.38 & 6.50 \\
\hline $\begin{array}{l}\text { KVP-Sutherland Paper Co. } \\
\text { at Parchment }\end{array}$ & 103 & 92 & 100 & 109 & 112 & 109 & 111 & 123 & 104 & 112 & 112 & 102 & 1289 & & \\
\hline $\begin{array}{l}\text { e) Simpson-Lee Paper Co. } \\
\text { at Vicksburg }\end{array}$ & 47.0 & 47.0 & 47.0 & 50.0 & 43.0 & 43.0 & 43.0 & 43.0 & 43.0 & 47.0 & 41.0 & 45.0 & 539.0 & 1.8 & 0 \\
\hline KALKASKA COUNTY & & & & & & & & & & & & & & & \\
\hline e) Village of Kalkaska & 4.51 & 5.70 & 5.60 & 4.28 & 4.94 & 6.27 & 5.90 & 6.20 & 5.90 & 5.60 & 4.56 & 4.52 & 63.98 & & \\
\hline KENT CI & & & & & & & & & & & & & & & \\
\hline City of cirandville & 17.8 & 16.2 & 16.6 & 16.5 & 22.6 & 47.8 & 45.0 & 31.9 & 22.1 & 17.5 & 15.8 & 16.4 & 286.2 & 2.67 & 0.41 \\
\hline City of torwell & 13.1 & 13.4 & 13.7 & 13.5 & 15.7 & 23.2 & 19.5 & 19.3 & 16.8 & 18.0 & 16.7 & 17.8 & 200.7 & & \\
\hline Paris Township & 29.6 & 24.6 & 26.0 & 28.4 & 42.1 & 61.0 & 65.2 & 47.9 & 38.6 & 32.4 & 30.0 & 29.2 & 455.0 & 3.55 & 0.57 \\
\hline Village of Sparta & 9.9 & 9.0 & 10.0 & 10.4 & 12.3 & 15.1 & 15.2 & 14.9 & 13.4 & 13.7 & 12.4 & 12.2 & 148.5 & 0.79 & 0.11 \\
\hline City of Wyoming & 156 & 145 & 157 & 170 & 231 & 313 & 303 & 245 & 183 & 151 & 146 & 157 & 2357 & 16.44 & 2.66 \\
\hline LAPEER COUNTY & & & & & & & & & & & & & & & \\
\hline Village of Imlay City & 6.6 & 6.5 & 8.6 & 7.7 & 9.1 & 12.2 & 10.7 & 14.0 & 8.6 & 9.5 & 11.1 & 8.5 & 113.1 & & \\
\hline city of lapeer & 13.5 & 12.5 & 14.3 & 13.9 & 15.6 & 19.0 & 20.2 & 17.7 & 15.4 & 14.7 & 13.5 & 13.7 & 184.0 & & \\
\hline
\end{tabular}


Table 3.--Reported ground-water pumpage by some Michigan municipalities, institutions, and industries (in million gallons).---Continued.

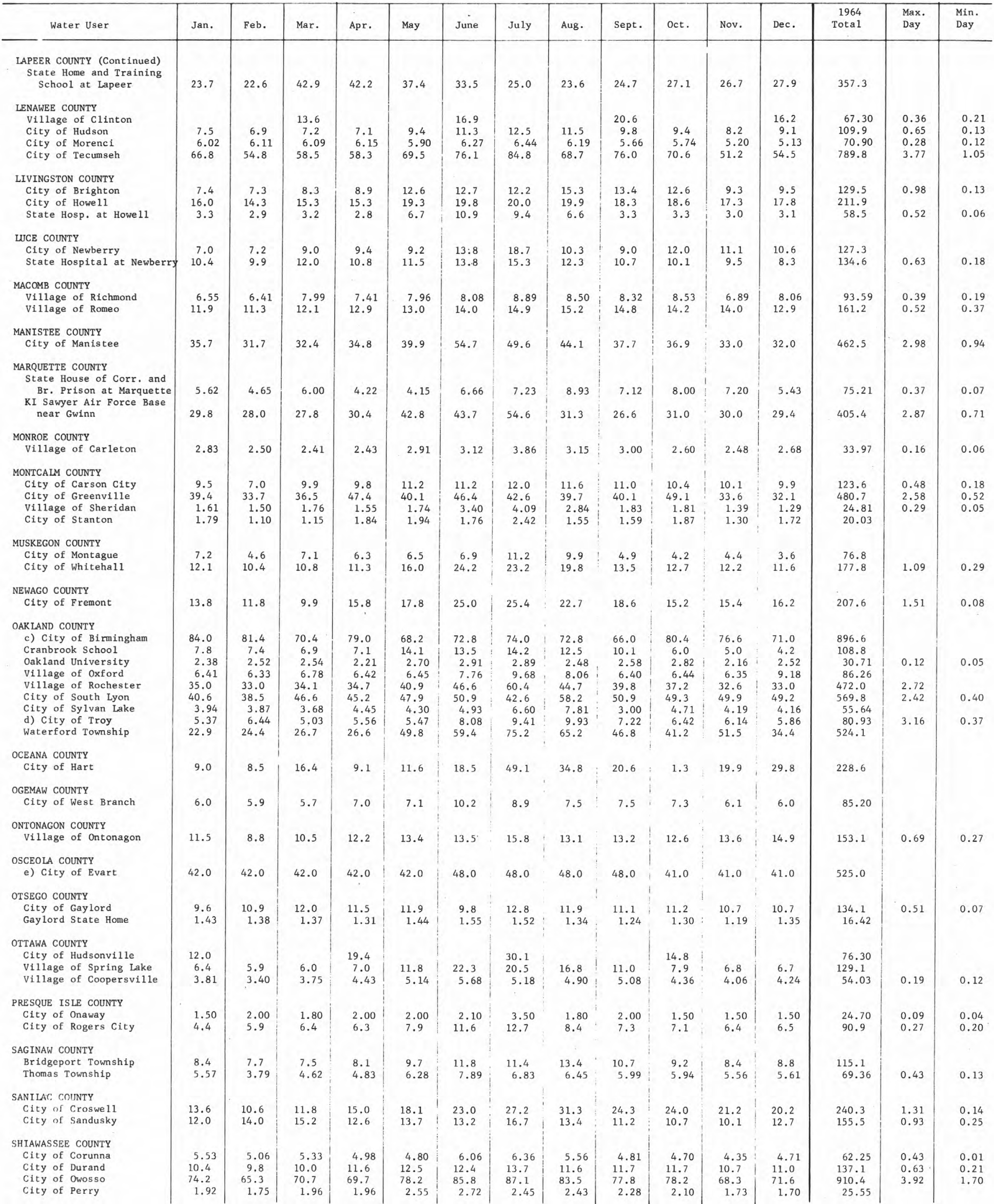


Table 3.--Reported ground-water pumpage by some Michigan municipalities, institutions, and industries (in million gallons).---Continued.

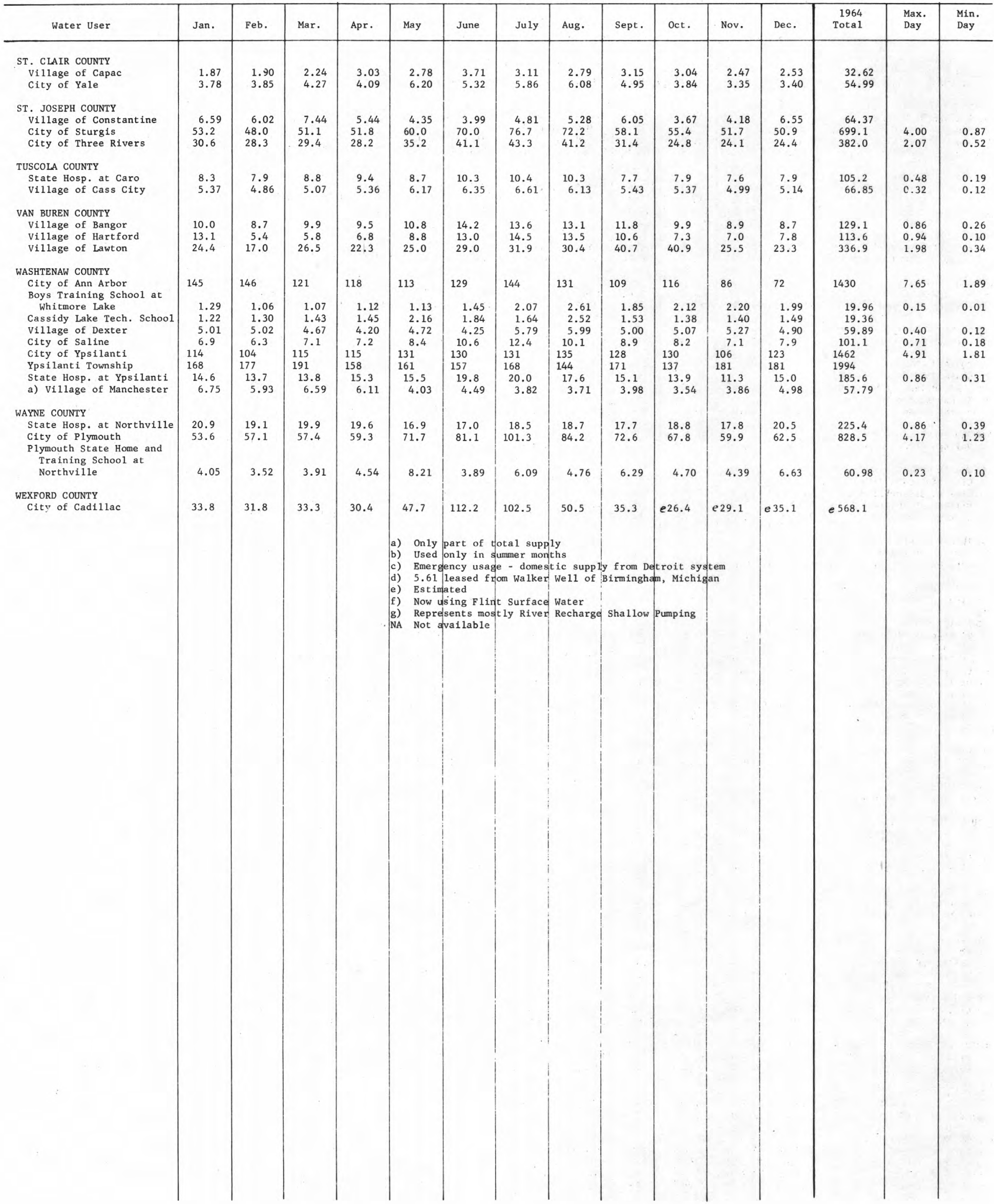


